\title{
CLUBE DE CIÊNCIAS E CULTURA: UMA ALTERNATIVA PARA A ALFABETIZAÇÃO EM CIÊNCIAS E SAÚDE
}

\author{
Maria Augusta Cabral de Oliveira
}

Tese de Doutorado apresentada ao Departamento de

Prática de Saúde Pública da

Faculdade de Saúde Pública da Universidade de São Paulo para

Obtenção do Grau de Doutor.

Área de concentração:

Serviços de Saúde Pública

Orientador: Profa. Dra. Glacilda Telles de Menezes Stewien CO-ORIILNTADOR: PROF. DR. FERNANIO LEFìVRE

São Paulo

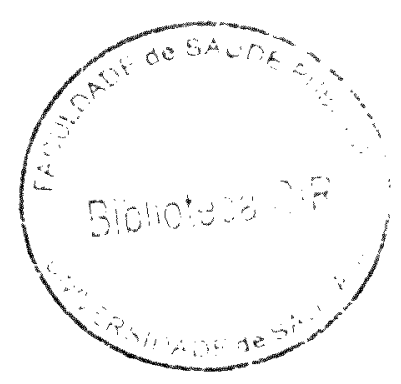


Autorizo, exclusivamente para fins acadêmicos e científicos, a reprodução total ou parcial desta tese, por processos fotocopiadores.

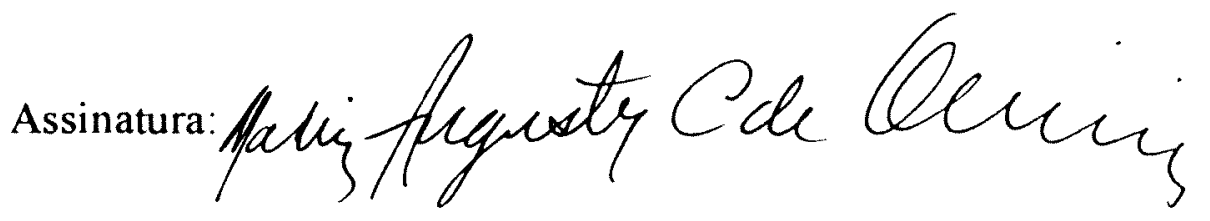

Data: 1: Afor 2001 


\section{AGRADECIMENTOS}

No caminho percorrido, ao longo da realização deste estudo, muitos me incentivaram e ajudaram. A eles meu imenso agradecimento:

Dra. Glacilda Telles de Menezes Stewien que "abraçou a causa" com interesse e amizade; Dr. Fernando Lefèvre que me socorreu quando foi preciso;

Dra. Márcia F. Westphal que me acolheu em seu grupo;

Dra. Isabel Maria T. B. Pereira e

Dra Eda T. de Oliveira Tassara com quem troquei muitas idéias.

Agradeço:

ao Centro da Juventude Santa Cruz, na pessoa de sua Diretora Josely A. Mateus Fernandes, que acreditou na proposta;

à Sociedade Brasileira de Silvicultura, na pessoa da Enga. Andrea Maffeis, que cedeu espaço e pessoal para a concretização da horta;

à Escola Estadual João Cruz Costa, na pessoa de sua coordenadora Maria Soares G. Garcia, por ter facilitado o contato com as professoras das crianças do Clube;

à Ana Maria Caricari que participou da minha "vida de estudante" nesta Faculdade, e que leu parte dos originais deste trabalho dando sugestões;

à acadêmica de Biologia Maria Fernanda Miranda que ajudou no trabalho "braçal" com as crianças;

à acadêmica de Ciências Sociais Joana Cabral de Oliveira que ajudou com os "teóricos das sociais", mundo novo para mim;

à Mariana Cabral de Oliveira pela diagramação final do texto no computador; ao Tiago Cabral de Oliveira e Georges Grenier pela preparação das gravações em CD;

à Anamélia B. Buoro com suas sugestões sobre a inclusão dos registros e imagens no texto; à bibliotecária M. Lúcia E. de Faria Ferraz pela revisão das referências deste trabalho. 
Um agradecimento muito especial:

à professora Maria Julieta Sebastiani Ormastroni, ex Diretora do IBECC, que me transmitiu sua experiência com os Clubes de Ciências,

ao Eurico Cabral de Oliveira com quem dividi quase que diariamente esta empreitada e, finalmente,

às crianças do Centro da Juventude: André, ...Antônio, ... Vagner, ... Fernandas, ... Mônicas, ... Jéssicas ..., com elas tudo foi possível.

Saio da Faculdade de Saúde Pública diferente de como entrei. Aprendi com todos, professores, colegas, familia, amigos e crianças.

Muito Obrigada! 


\section{RESUMO}

\section{Oliveira MAC. Clube de Ciências e cultura: uma alternativa para a alfabetização em ciências e saúde. São Paulo; 2001. [Tese de Doutorado- Faculdade de Saúde Pública da USP]}

A educação tem sido definida como uma das formas mais eficientes de promover o desenvolvimento individual. Ela pode ter lugar tanto no âmbito escolar como fora dele, caracterizando, respectivamente, as chamadas educação formal e não-formal. Os Clubes de Ciências constituem um exemplo típico de espaço não-formal para ensino e aprendizagem, congregando educandos de forma sistemática e permanente. Nele têm lugar ações educativas voltadas não só para a aquisição e ampliação de conhecimentos, que fazem parte da cultura científica, como também para a formação e desenvolvimento das potencialidades de seus participantes. Assim, através dos objetivos e estratégias traçadas, - clube permite desenvolver e completar a formação dos educandos de maneira socializada, tanto no aspecto pessoal como social e, inclusive, de cidadania. Por trabalhar não só informações mas também habilidades e atitudes, favorece o desenvolvimento de competências. No clube, sob orientação do professor/orientador, educandos de diferentes idades e bagagens organizam e conduzem pequenos projetos educativos sobre os mais variados temas escolhidos segundo os interesses e motivações do grupo, dividindo um espaço democrático, participando do encaminhamento e execução de tarefas, intercambiando idéias e construindo conhecimento. Este trabalho se propôs, através de uma abordagem metodológica qualitativa, aplicar, estudar e avaliar um modelo educativo de Clube de Ciência e Cultura. Esse foi voltado para a alfabetização em ciências e saúde, de crianças de sete a onze anos, que freqüentavam o Centro Comunitário Santa Cruz e que eram moradoras da Favela Vila Nova Jaguaré, em São Paulo, capital. O programa aplicado, tendo como tema gerador "Alimentos e Nutrição", permitiu, além dos vários 
trabalhos desenvolvidos, a implantação de uma horta na comunidade. Utilizando estratégias metodológicas como observação direta, entrevistas e aplicação de questionários, verificou-se a atuação efetiva do Clube na sua proposta educativa, com apreensão de conteúdo e desenvolvimento de atitudes pelos educandos, indicando ser este um modelo adequado para intervenções educacionais, promovendo saúde e cidadania. $O$ programa foi considerado um sucesso por vários segmentos da comunidade e pelos indicadores escolhidos para análise, como indica sua continuidade após o encerramento do período definido para a realização deste estudo, no primeiro semestre de 2000 .

Descritores: Alfabetização em Ciências. Clube de Ciências. Educação Não-Formal. Educação em Saúde. Promoção em Saúde. 


\section{SUMMARY}

Oliveira MAC. Clube de Ciências e Cultura: uma alternativa para a alfabetização em ciências e saúde. [ Science and Culture Club: an alternative to literacy in science and health] São Paulo (BR); 2001. [Tese de Doutorado- Faculdade de Saúde Pública da USP].

Education has been considered as one of the most effective ways to promote personal development. This can be achieved through different ways, be it within the school as well as outside the school, better known as formal and non-formal education. The Science Clubs represent a typical example of non-formal space for teaching and learning, assembling students on a systematic and permanent manner. This is a place where educational action is concemed not only with the acquisition and summing up of scientific knowledge, as well as to capacity building and development. Therefore, as a consequence of the objectives and strategies established before hand, the club will make possible the build up of scientific knowledge in a social way, contemplating personal and social aspects, including the grow up of citizenship attitudes. By working not only with information, but also with abilities and attitudes, it favors the development of competence. Under the guidance of the teacher/supervisor the work in the club proceeds through the development of small educational projects about a variety of themes selected by the students themselves following their legitimate motivations. This takes place within a democratic space with broad participation of the young, taking part in every step of the process, interchanging ideas and building knowledge. This work was devised to apply, develop and evaluate an educational model of Science and Education Club aiming to attain a minimum of literacy in science and health, utilizing a qualitative approach. The program was developed at the Santa Cruz Community Center, for children aged seven to eleven years, living in a nearby slum (Favela Vila Nova Jaguaré), at São Paulo city. The 
theme selected was Food and Nutrition. Among the many activities developed the build up of a vegetable garden stands up. Through the utilization of direct observation methodology, interviews and questionnaires it became clear that the Club had accomplished its educational proposals resulting not only in the acquisition of scientific knowledge but also in a change in attitudes toward life, showing its potential as a feasible model to education and promotion of health and citizenship. The program was considered a success by different segments of the community and by the indicators selected for its evaluation. A rewarding result was that the activity has been going on till today since this study reached its planed end in the first semester of the year 2000 .

Descriptors: Literacy in Science. Science and Education Club. Non-Formal Education. Health Education. Health Promotion. 


\section{ÍNDICE}

I INTRODUÇÃO

1 A Educação e o Ensino de Ciências 1

2 O Processo Educativo: Ensino Formal e Não-Formal 8

2.1 A Educação Não-Formal $\quad 11$

2.2 As Características Gerais de um Clube de Ciências e Cultura $\quad 14$

3 A Educação e a Promoção em Saúde 16

3.1 A Alfabetização em Ciências e Saúde 22

$\begin{array}{ll}4 \text { O Objeto de Estudo } & 28\end{array}$

5 Os Objetivos Gerais e Específicos $\quad 30$

II MÉTODOS E DISCUSSÃO METODOLÓGICA 32

1 A Aproximação 32

2 A Estruturação $\quad 34$

2.1 A Opção pela Análise Qualitativa e a Metodologia
Pesquisa-ação

3 O Controle da Subjetividade e o Rigor Cientifico 38

4 Os Procedimentos Metodológicos e suas Etapas 39

4.1 O Local de Estudos e seus Participantes 39

4.2 O Período e o Tema a ser Desenvolvido 41

4.3 As Crianças e as Implicações Éticas $\quad 42$

4.4 A Fase exploratória no Trabalho de Campo 42

4.5 O levantamento de dados $\quad 43$

4.5.1 A Observação 44

4.5.2 As Entrevistas $\quad 45$

4.5.3 Visita à Escola 48

5 A Análise dos Dados 49

6 A Teorização Novamente 49 
1 O Clube Imaginado

2 O Clube Vivido $\quad 56$

2.1 Caracterização do Espaço Físico e Funcional do Clube e de seus Participantes

2.2 Caracterização das Atividades, sua Condução

e Produtos Resultantes

2.2.2 A Cronologia do Trabalho: a Horta - Agosto de 99 a Junho de 2000

3 Análise e Discussão sobre as Estratégias Utilizadas no trabalho do Clube

3.1 Os Objetivos

3.2 Os Conteúdos

3.3 Formas de Trabalho e Respostas do Educandos

3.4 Interação Educador/Educandos e dos Educandos Entre Si

4 Os Participantes e seus Discursos $\quad 94$

4.1 As Crianças $\quad 94$

$\begin{array}{ll}4.2 \text { A Diretora } & 110\end{array}$

4.3 A Monitora $\quad 111$

4.4 As Crianças na Escola $\quad 112$

5 O Clube de Ciências e Cultura e a promoção em Saúde 114

$\begin{array}{lr}\text { IV CONSIDERAÇÕES FINAIS } & 118\end{array}$

$\begin{array}{lr}1 \text { Reflexões } & 118\end{array}$

$\begin{array}{ll}2 \text { Repercussões do Clube } & 121\end{array}$

3 Conclusões $\quad 122$

$\begin{array}{lr}\text { V REFERÊNCIAS BIBLIOGRÁFICAS } & 124\end{array}$

$\begin{array}{ll}\text { VI ANEXOS } & 136\end{array}$ 


\section{SOBRE ESTE ESTUDO}

Não sei precisar em que momento da minha vida estabeleci relações fortes com a questão do conhecer não - formal. Na verdade, reconheço que levada pelo incentivo materno, desde pequena, vivi experiências educativas que deixaram marcas na minha trajetória pelo ensino. A principal foi a participação na Feira de Ciências da Cidade de São Paulo, no final de década de 50, onde apresentei um "estudo" a que dei o título de PEDRAS BRASILEIRAS. Naquela época, estudante de ginásio, eu estava fascinada e muito envolvida em conhecer e identificar rochas e minerais que colecionava e cujo conteúdo não fazia parte do elenco de assuntos das aulas de Ciências. Fui atrás de livros e do professor, fiquei "sabida em pedras", nomes, composição química, formas de cristalização, origens e outras informações mais, que até me ajudaram, posteriormente, na disciplina Geologia, quando fiz o curso de Ciências Biológicas.

Com relação aos Clubes de Ciências, minha ligação se estabeleceu em meados da década de 80. Já professora, passei a integrar a equipe de professores do IBECC-UNESCO (Instituto Brasileiro de Educação Ciência e Cultura), que vinha atuando há 40 anos em educação. Nos últimos 15 anos, aquela instituição centrou esforços no ensino não-formal, com projetos e programas voltados para a implantação e desenvolvimento de clubes, visando apoiar o ensino formal

Essas vivências fortaleceram minha crença no trabalho educativo não-formal, como forma de possibilitar e ampliar o conhecimento, completando o ensino escolar. Minha experiência apoiava-se em clubes vinculados à escola. Daí, este trabalho com crianças de favela, aplicando a mesma filosofia dos clubes, foi um outro desafio. Consegui envolvê-las, e os resultados que aqui estão foram surpreendentes e prazerosos, porque as crianças, apesar de suas realidades e histórias, se mostraram abertas, participando e respondendo ao trabalho com compromisso e dedicação. Ainda hoje permaneço com elas e continuo o trabalho, parte do qual relato nesta tese.

Mais do que nunca acredito plenamente nas diferentes formas de ensinar e aprender e creio ser esta, a educação não-formal, um grande potencial transformador. 

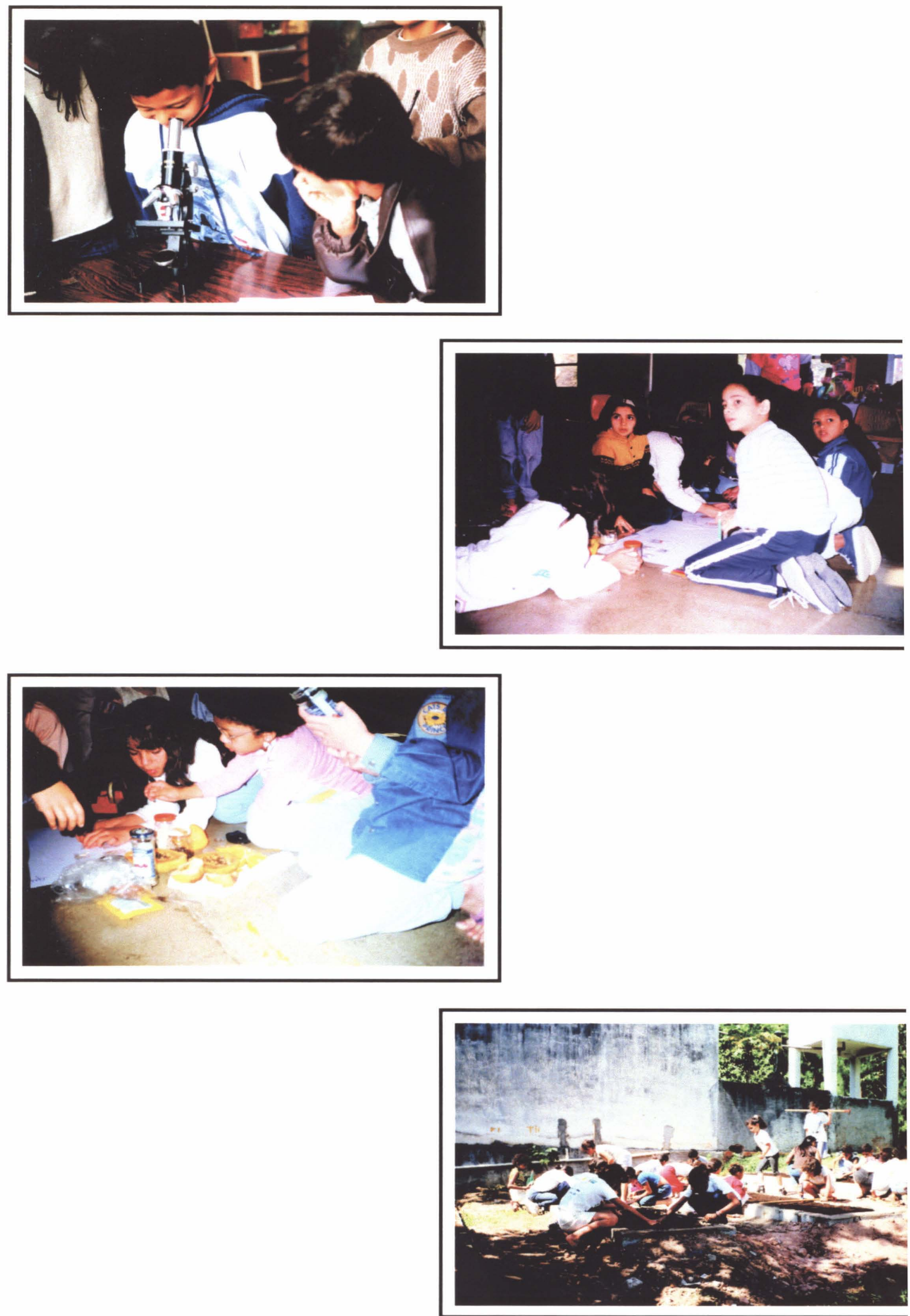


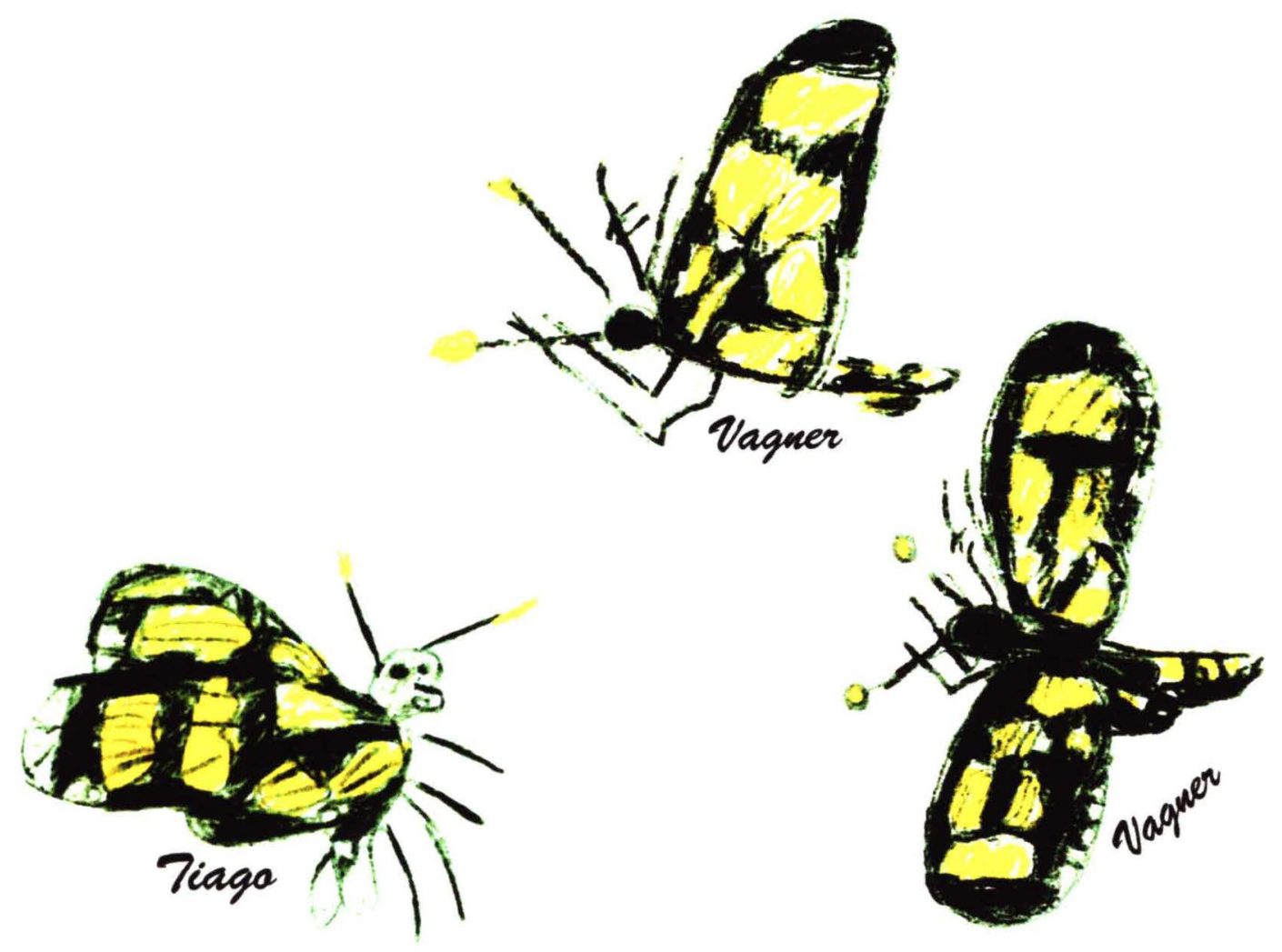


"O mundo nâo é aquilo que eu penso, mas aquilo que vivo. Sou aberto ao mundo, me comunico indubitavelmente com ele, mas não o possuo. Ele é inesgotável”

(Merleau Ponty)

“A verdadeira viagem de descobrimento não consiste em buscar novas paisagens, mas novos olhos"

(Marcel Proust) 


\section{I - INTRODUÇÃO}

Ao propor ações educativas voltadas para o ensino de ciências e saúde, utilizando como modelo um Clube de Ciências e Cultura, tornou-se necessária uma reflexão e análise não só no campo da saúde, mas, principalmente, no da educação, de modo a obter referências teóricas e fundamentação para atuar na pesquisa e na prática pedagógica, dada a interface estabelecida entre as áreas referidas.

Para esta reflexão vários aspectos foram analisados, começando pelas concepções de saúde e educação, considerando os objetivos, níveis e formas de educar, passando pelas teorias subjacentes, de ordem pedagógica e social, que não poderiam deixar de estar presentes, além do equacionamento de uma pesquisa para entender e interpretar o significado do referido clube e sua ação educadora.

Neste capítulo serão apresentadas, de modo sucinto, as questões teóricas referentes ao conceito de educação, seu processo, o ensino das Ciências, a educação e promoção em saúde, além da caracterização do objeto deste estudo, visando traçar as diretrizes para empreender a sua análise.

\section{A Educação e o Ensino de Ciências}

A educação é um processo inerente à condição humana. Ela conduz à formação e capacitação dos individuos, preparando-os para a participação da vida em sociedade. LIBÂNEO (1994) a caracteriza como fenômeno social e universal, sendo necessária à existência e funcionamento das sociedades, que estabelecem relações ativa e transformadora, de modo necessário e inevitável dos individuos envolvidos socialmente. $\mathrm{O}$ referido autor declara que a prática da educação, que envolve aspectos fundamentais 
como conteúdos, objetivos e atuação docente, está subordinada às exigências sociais, políticas e ideológicas.

As tendências encontradas no processo educativo implicam, entre outras dimensões, as concepções e formas de atuação e refletem a história e a evoluçãu da educação. Tais aspectos podem ser reconhecidos no texto de LIBÂNEO (1994), sobre o desenvolvimento histórico da didática, onde são traçadas, de modo resumido, as diversas linhas pedagógicas. Essas tendências, com reflexos no ensino de Ciências, advogam pensamentos e ações metodológicas, que definem trajetórias e estruturam as diferentes abordagens. $O$ referido autor analisa as idéias inspiradoras, iniciando com Comênio (século XVII), continuando com Rousseau (séc. XVIII), Pestalozzi (séc. XVIII) e Herbart (séc. XIX), entre outros. As idéias contidas nas reflexões desses autores forneceram o arcabouço básico para a demarcação de duas concepções pedagógicas definidas, identificadas como Tradicional e Renovada.

A Pedagogia Tradicional, ainda muito presente no fazer de nossas escolas, foi inspirada nas concepções de Herbart (LIBÂNEO, 1994). Ela se caracteriza por uma ação centrada no professor, privilegiando o conhecimento universalmente acumulado. Nela o educador é a autoridade intelectual e imprescindível para a transmissão dos conteúdos. $O$ mundo, assim, é conhecido pelos alunos através “dos olhos do professor”, sendo estes receptáculos passivos, que serão preenchidos, e onde gradativamente serão armazenadas as informações. PAULO FREIRE (1996) caracteriza esta forma de atuação educativa como educação bancária, pois o educador, através de exposições teóricas, enche o educando, "depositando" conhecimentos que devem ser armazenados na memória. Os educandos assim conduzidos devem chegar todos aos mesmos resultados, segundo modelos definidos, não sendo consideradas as diferenças individuais presentes

SAVIANI (1989) explica que nessa abordagem fica caracterizado que o conhecimento é garantido pela presença do professor e é independente do interesse do 
aluno. LIBÂNEO (1994) completa explicando: uma concepção de ensino como impressão de imagens propiciadas ora pela palavra do professor ora pela observação sensivel.

A Pedagogia Renovada, opondo-se à Tradicional, agrupa as linhas renovadoras de ensino. Este movimento valoriza a criança, que é vista como indivíduo, possuidor de liberdade, iniciativa e interesses. Nessa dimensão, ela se torna participante do processo de aprendizagem, segundo suas capacidades e ritmo. Tal tendência, inspirada nas idéias de Rousseau, tomou impulso a partir do início de século $\mathrm{XX}$, dando conformação ao movimento da educação nova, na qual se incluiu o movimento das "escolas novas". Nessa abordagem, o método é essencialmente ativo e a escola não é uma preparação para a vida, é a própria vida (LIBÂNEO, op. cit.) - demonstrando assim, a preocupação de que a educação promova e estimule o educando, foco do trabalho escolar, a crescer e se desenvolver. Desta forma, a escola é vista como espaço de vivência, e deve dar condições para que, através de suas atividades, as potencialidades, capacidades e interesses dos alunos sejam ativados.

Fazendo parte da pedagogia renovada, há uma corrente denominada Pedagogia Cultural, que considera a educação como fato de cultura. Nela cabe ao docente assumir o papel de estimulador da apropriação de valores culturais, por parte dos alunos. A pedagogia cultural, originária de Dilthey (início do século $\mathrm{XX}$ ), supera a oposição entre cultura subjetiva e objetiva e indivíduo e sociedade, mas coloca o educando, que vive em um mundo sócio-cultural próprio, imerso no histórico da sociedade ( LIBÂNEO, 1994)

Especial atenção deve ser dada aos estudos propostos por Jean Piaget e Lev Vygostky. Seus estudos geraram teorias sobre a gênese dos conceitos elaborados pelas crianças, contribuindo de modo fundamental para mudanças no processo de educação, dentro da Pedagogia Renovada. Predominantemente sustentada pela interação homem e mundo, a teoria cognitivista piagetina explica o processo de aprendizagem. Não focando 
um ou outro lado da interação sujeito-objeto, ela explicita o modo como as estruturas internas do sujeito, representadas pela apreensão, processamento e organização das informações, as formas de pensamento e os comportamentos referentes à tomada de decisões, se processam segundo fases do desenvolvimento, conduzindo à construção do conhecimento (BEARD, 1978; MIZUKAMI, 1986). Vygostky propôs teorias estabelecendo relações genéticas e funcionais entre o pensamento e a linguagem, explicando a formação dos conceitos e o papel relevante da instrução socializada efetuada pela escola. Seus estudos estabelecem relações entre a aprendizagem e o desenvolvimento intelectual e potencial da criança em idade escolar. Para o autor, a aprendizagem escolar orienta e estimula os processos de desenvolvimento, criando o que denominou de desenvolvimento potencial, que determina o que a criança pode fazer no futuro, através da maturação dos processos internos gerados pelo aprendizado (VYGOTSKY, 1979 e 1988)

A estes teóricos, é preciso acrescentar as idéias sócio-pedagógicas do educador Paulo Freire. Voltada para uma educação problematizadora, a proposta de Freire convoca a participação ativa do educador e educando no processo. A ênfase está no sujeito cognoscente, que é histórico e contextualizado, que deve ser sujeito da própria educação. Freire apresenta visão interacionista entre o homem e seu mundo, enfatizando a necessidade de diálogo entre ensinante e aprendente, como forma de superar não só esta dualidade, mas principalmente como forma de se inserir e se comprometer na práxis transformadora. A educação é ato político e fator fundamental para a passagem de formas mais primitivas de consciência para a consciência crítica, em abordagem caracterizada como sócio-cultural (MIZUKAMI, 1986; FREIRE, 1996).

Em relação às várias interpretações do processo de ensino-aprendizagem, MIZUKAMI (1986) apresenta-as situando-as nos contextos histórico, cultural e sóciopolítico. A autora faz uma síntese, para a realidade brasileira, das posições segundo referências epistemológicas, na relação entre sujeito e meio, e sua repercussão nas ações 
educativas, considerando que estas são intencionais. Dessa análise configuram-se cinco categorias de concepções caracterizadas como: tradicional, comportamentalista, humanista, cognitiva e sócio-cultural. A autora não incluiu o que considera como a sexta espécie, a denominada didacticista, cujos pressupostos tendem a se assentar no "Movimento da Escola Nova". Esta não-inclusão é justificada pelo fato de as diretrizes estarem incluídas nas outras abordagens, apesar de ter tido uma influência histórica na formação de professores.

As propostas pedagógicas, Tradicional e Renovada, e as abordagens do processo se refletem nos vários aspectos pertinentes ao ensino e aprendizagem, considerando os contextos educativos e de metodologia de ensino. Elas repercutem nas relações estabelecidas entre professor e alunos, estruturando uma visão de mundo, homem e sociedade bastante próprios. Ao apresentar os resultados deste estudo, as análises e as discussões estabelecidas nos remeterão à estas pedagogias e às teorias a elas pertencentes.

Para o ensino das Ciências, cujo corpo de conhecimentos inclui os conceitos de Saúde, há que se considerar, ainda, o papel desempenhado pelas disciplinas Biologia, Química e Física na formação dos educandos. KRASILCHIK (1987) em seu estudo sobre o currículo de Ciências, apresenta as finalidades máximas buscadas nas diferentes propostas curriculares e as respostas conseguidas em sala-de-aula. Para tanto traça uma evolução histórica e cronológica, a partir da década de 50, das tendências do ensino de Ciências. Estes dados, presentes no quadro abaixo, mostram uma síntese de sua reflexão. 
Quadro 1. A evolução do Ensino de Ciências (seg. Krasilchik, 1987, modificado).

$\begin{array}{lllll}\text { Fator } & 1950 & 1960 & 1970 & 1980\end{array}$

\begin{tabular}{|c|c|c|c|c|}
\hline Situação Mundial & Guerra Fria & Crise Energética & $\begin{array}{l}\text { Problemas } \\
\text { Ambientais }\end{array}$ & $\begin{array}{l}\text { Competição } \\
\text { Tecnológica }\end{array}$ \\
\hline Situação Brasileira & \multicolumn{3}{|c|}{ Industrialização/Democratização Ditadura } & Transição Politica \\
\hline $\begin{array}{l}\text { Objetivos do Lnsino } \\
\text { de } 1^{\circ} \text { e } 2^{\circ} \text { graus }\end{array}$ & Formar Elite & Formar Cidadãos & $\begin{array}{l}\text { Preparar } \\
\text { Trabalhadores }\end{array}$ & $\begin{array}{l}\text { Formar Cidadãos- } \\
\text { Trabalhadores }\end{array}$ \\
\hline $\begin{array}{l}\text { Influências } \\
\text { Preponderantes no } \\
\text { Ensino }\end{array}$ & Fscola Nova & $\begin{array}{l}\text { Comportamenta- } \\
\text { lismo }\end{array}$ & $\begin{array}{l}\text { Comportamenta- } \\
\text { lismo mais } \\
\text { Cognitivismo }\end{array}$ & Cognitivismo \\
\hline $\begin{array}{l}\text { Objetivos da } \\
\text { Renovação do } \\
\text { Ensino de Ciências }\end{array}$ & $\begin{array}{l}\text { Transmitir } \\
\text { Informações } \\
\text { Atualizadas }\end{array}$ & $\begin{array}{l}\text { Vivenciar o Método } \\
\text { Científico }\end{array}$ & $\begin{array}{l}\text { Pensar Lógica e } \\
\text { Criticamente }\end{array}$ & $\begin{array}{l}\text { Analisar } \\
\text { Implicações Sociais } \\
\text { do Desenvolv. } \\
\text { Científico e Tecnol. }\end{array}$ \\
\hline $\begin{array}{l}\text { Visão da Ciência } \\
\text { nos Currículos de } 1^{\circ} \\
\text { e } 2^{\circ} \text { Graus }\end{array}$ & $\begin{array}{l}\text { Atividade Neutra } \\
\text { Enfatizando } \\
\text { Produtos }\end{array}$ & $\begin{array}{l}\text { Evolução Histórica } \\
\text { Enfatizando o } \\
\text { Processo }\end{array}$ & \multicolumn{2}{|c|}{$\begin{array}{l}\text { Produto do Contexto Econômico, Político, } \\
\text { Social e de Movimentos Intrínsecos }\end{array}$} \\
\hline $\begin{array}{l}\text { Metodologia } \\
\text { Recomendada } \\
\text { Dominante }\end{array}$ & Laboratório & $\begin{array}{l}\text { Laboratório mais } \\
\text { Discussões de } \\
\text { Pesquisa }\end{array}$ & \multicolumn{2}{|c|}{$\begin{array}{l}\text { Jogos e Simulações. Resolução de } \\
\text { Problemas }\end{array}$} \\
\hline $\begin{array}{l}\text { Instituições que } \\
\text { Influem na } \\
\text { Proposição de } \\
\text { Mudanças Nivel } \\
\text { Institucional }\end{array}$ & $\begin{array}{l}\text { Associações } \\
\text { Profissionais } \\
\text { Cientificas e } \\
\text { Instituições } \\
\text { Governamentais }\end{array}$ & $\begin{array}{l}\text { Projetos } \\
\text { Curriculares. } \\
\text { Organizações } \\
\text { Internacionais }\end{array}$ & $\begin{array}{l}\text { Centros de Ciências } \\
\text { Universidades }\end{array}$ & $\begin{array}{l}\text { Organizações } \\
\text { Profissionais, } \\
\text { Cientificas e de } \\
\text { Professures. } \\
\text { Universidades }\end{array}$ \\
\hline
\end{tabular}

Podemos constatar que no Quadro 1 , a análise se limita até a década de 80 . Posteriormente, em encontros sobre o Ensino de Biologia, a autora pôde dar continuidade à sua reflexão chamando atenção, por um lado, para os novos conhecimentos gerados a partir do avanço da Biotecnologia, Medicina, Nutrição e Ecologia, e, por outro, para a diversidade de cultura e as múltiplas influências nas crianças e jovens. Tais fatores, somados às novas tecnologias e à informática, requerem 
uma nova perspectiva de ensino, requisitando por parte do professor uma nova atuação, de pesquisador (KRASILCHIK, 1991). A referida autora salienta, entretanto, que a possibilidade de experimentar com animais e plantas no seu habitat não se substitui, chamando a atenção para o desenvolvimento dos domínios cognitivo e afetivo. Ela convoca a atuação voltada para a alfabetização biológica, em contextos sociais diferentes, segundo prioridades, como forma de aperfeiçoar a cidadania e melhorar a qualidade de vida (KRASILCHIK, op. cit.)

MENEZES (2000), em seu texto sobre o balanço do ensino de Ciências no final deste século e a sua perspectiva para o próximo milênio, aponta funções fundamentais que devem ter sido alcançadas pelas escolas. Ele cita a busca do desenvolvimento da inteligência de todos os educandos e não só de apenas alguns; uma açâo de quem aprende e não sobre quem aprende; a vivência e o diálogo coletivos como elementos de formação e humanização; e a aceitação das diferenças individuais quanto às caracteristicas, necessidades e habilidades, sem a proposta de transformar todos os alunos em iguais e assim avaliá-los.

Porém, apesar de todos os esforços transformadores, encontra-se ainda um ensino de Ciências e Saúde caracteristicamente centrado na transmissão e memorização de conceitos, termos e fórmulas, dentro da abordagem tradicional, em interação vertical entre professor e aluno e onde o livro didático é o organizador do currículo e do trabalho de sala-de-aula.

MENEZES (2000) reconhece que o meio ambiente, a saúde e os recursos naturais e tecnológicos têm estado presentes nos currículos, porém não basta expor os alunos aos problemas sobre estes temas, é preciso apresentá-los em "exercicio real'. Não se deve portanto tratar as questões apenas no plano informativo, mas debatê-las, como forma de promover e formar opinião e construir uma visão crítica, permitindo a tomada de decisões, por parte dos educandos (ZANETIC, 1991). 


\section{O Processo Educativo: Ensino Formal e Não Formal}

A proposta para a Educação está quase que exclusivamente centrada em estruturas formais de planejamento, implementação e administração de programas educacionais. A escola, representando o ensino formal, com seu curriculo organizado por séries e faixas de idade, é a principal agência responsável por essa abordagem. A escola, correspondendo ao ambiente próprio para o desenvolvimento do conhecimento, em especial o cientifico, tem um papel fundamental na formação e preparação de crianças e jovens. Neste contexto ela se caracteriza pela aplicação de poder através da seleção de currículo, escolha da metodologia, estrutura institucional e padrões de relação com a comunidade, contribuindo para o estabelecimento do sistema escolar ao lado de outras formas de educação para a formação do cidadão.

Vários autores (CAMPOS, 1985; LIBÂNEO, 1994; FREIRE, 1996) advogam a importância da atuação da escola no processo educativo. Estes, no entanto, enfatizam que a educação pode ocorrer em outras instâncias. LIBÂNEO (1994) explica a educação como prática social, especificando que ela pode ocorrer em uma ampla variedade de “instituições” e de atividades humanas como familia, escola, organizações políticas e sindicais, igrejas e na comunicação de massa.

Em relação à escola, SOLÉ e COLL (1998) fazem uma breve reflexão, chamando a atenção para o seu caráter social e socializador. Segundo esses autores a escola é responsável, através de suas práticas, pelo acesso, interpretação e conservação de uma cultura, devendo assegurar o desenvolvimento não só cognitivo, mas das capacidades pessoal, social e motora dos educandos. Eles preconizam ainda, que o desenvolvimento do aluno ocorre quando há atividade mental construtiva promovendo sua transformação em individuo línico, no contexto de um grupo social determinado, salientando que neste processo os agentes culturais são imprescindiveis. 
Em seu texto, CAMPOS (1985) analisa de modo extenso as agências formais e informais de educação, enfocando a questão dos valores, o papel da escola e da familia. Ao discutir sobre a família e os meios de comunicação, o autor afirma que estas instituições têm ação de superposição em relação à escola, embora, em outras vezes, elas determinem interferências que alteram sua direção e até anulam sua ação

ABREU JUNIOR (1996), ao discutir a transdisciplinaridade, menciona a importância dos espaços informais, considerando-os tão relevantes quanto a escola na transmissão de conhecimentos científicos, sendo exatamente o fulcro desta proposta.

Em geral, a estrutura escolar tende a ser pouco flexível, hierárquica e fortemente fechada em suas disciplinas, transmitindo conceitos, atitudes, valores e normas, além da cultura da classe dominante. Ela se distancia das aspirações e necessidades dos grupos socialmente menos favorecidos.

Países como China, Índia, Indonésia e mesmo o Brasil têm tentado enfatizar a importância em investir no desenvolvimento humano, buscando programas educativos alternativos, que complementam o sistema formal de ensino (RANAWEERA, 1989). Estes programas são, muitas vezes, o principal ou único contato que os jovens podem ter com o conhecimento elaborado, em especial, para aqueles que estão fora do sistema escolar, ou que estão no sistema, mas de maneira desigual.

Formas alternativas de educação têm sido aplicadas com relativo sucesso, permitindo trabalhar não só os conteúdos e informações, mas também as habilidades e atitudes. Tais propostas, também denominadas não convencionais de educação, têm sido efetivas, atuando na educação e promoção individual e coletiva de educandos, aumentando o repertório e objetivando uma qualidade de vida melhor. Elas são representadas por clubes de ciências; clubes e oficinas de verão; feiras de ciências e 
saúde; acampamentos científicos; entre outros. Vêm ocorrendo junto às escolas, prefeituras, igrejas e centros comunitários, permitindo um trabalho mais concentrado e sistemático de temas e conteúdos e envolvendo não só alunos, com várias idades e bagagens, como professores/ educadores, familiares e membros da comunidade.

Ao participar desses trabalhos, os alunos são vinculados a programas mais flexíveis, inovadores e adaptados aos seus interesses, produzindo resultados mais rápidos, especialmente pela adoção de métodos de ensino/aprendizagem que superam, em qualidade, as abordagens tradicionais de ensino.

RANAWERRA (1989) aponta que o trabalho não convencional deve estar voltado para reduzir o poder e controle exercidos pela instituição e pelo professor, devendo adotar modelos pedagógicos que permitam:

- à participação dos educandos, inclusive no planejamento e organização do processo, podendo definir temas e assuntos, critérios e avaliação;

- um processo pedagógico que responda ao interesse, ritmo e tempo dos educandos;

- à participação da comunidade, tanto no processo instrucional como na organização social dos centros de aprendizado;

- o reconhecimento e integração da cultura e bagagem de conhecimento espontâneo dos educandos no currículo e nas experiências de aprendizagem.

Tais pressupostos aproximam-se muito dos conceitos e propostas preconizados por Paulo Freire, dentro de uma abordagem sócio-cultural, como mostra MIZUKAMI (1986). Em sua abordagem, homem e mundo interagem e a ênfase está no sujeito, situado no tempo e espaço, inserido no contexto histórico, sendo elaborador e construtor do seu conhecimento. Esse sujeito é criador de sua cultura e integrado no contexto de vida. Reflete sobre seu ambiente e deve ser comprometido com sua realidade, respondendo criticamente aos desafios e intervindo de maneira criativa e original (MIZUKAMI, op. cit.) 
Em tal contexto, não há receitas e modelos a serem seguidos. Desafiar o sujeito é dar condições para que ele busque respostas para se modificar e modificar sua realidade, transcendendo da simples compreensão para uma dimensão mais significativa, crítica e problematizadora. FREIRE (1974) afirma que é preciso que a educação esteja em seu conteudo, em seus programas e em seus métodos, adaptada ao fim que se persegue: permitir ao homem chegar a ser sujeito, construir-se como pessoa, transformar o mundo e estabelecer com os outros homens relações de reciprocidade, fazer a cultura e a história.

Ao teorizar e refletir sobre as formas de ensino, é necessário fechar o foco sobre o ensino não-formal, dimensão estrutural deste estudo.

\subsection{A Educação Não-Formal}

As concepções e atitudes que a criança tem frente à Ciência são resultados de experiências individuais, originadas fora e dentro da escola. Essas noções são incorporadas e fazem parte do acervo que cada uma tem, estruturando a sua bagagem de conhecimentos

MAARSCHALK (1988) mostra que as relações e experiências fora da escola têm papel importante na alfabetização científica. Assim, procedimentos planejados como visitas a museus, trabalhos de campo, educação através da TV e rádio são situações educacionais, que explicam e compõem o que o autor caracteriza como educação nãoformal. Para esse, a abordagem não-formal é um processo planejado, sistemático, altamente adaptável às circunstâncias e instituições, fora da esfera escolar. 
Ao caracterizar a não-formal, MAARSCHALK (op. cit.) chama atenção para outra modalidade de aprendizagem, a informal. Esta se aplica a situações mais espontâneas da vida, como conversas com amigos e familiares; leituras de revistas; hobbies e vida social. O referido autor enfatiza que os diferentes tipos de aprendizagem, diferem na sua essência do contexto em que ocorrem. O autor cita WHITE (1988) para explicar que se entende por contexto as condições sob as quais ocorre o aprendizado.

LIBÂNEO (1994) analisa e discute as formas de educação categorizando-as como não-intencional e intencional. $\mathrm{O}$ autor se refere à primeira modalidade como sendo as influências do contexto social e do meio sobre os indivíduos, resultando na aquisição informal de conhecimentos, experiências, valores e práticas. Essa definição se contrapõe à intencional, cuja proposta inclui objetivos, conteúdos e tarefas, definidas conscientemente e sendo vinculadas às instituições escolares e extra-escolares.

Ao descrever as diferentes abordagens, TAMIR (1991) faz uma sintese das características e as coloca no quadro apresentado a seguir: 
Quadro 2. Características dos contextos de aprendizagem (segundo Tamir, 1991, modif.)

\begin{tabular}{|c|c|c|c|}
\hline Atributos & Formal & Não-formal & Informal \\
\hline I.OCAI & Sala de aula/ Escola & Não-esciola & $\begin{array}{c}\text { Casa/ Nenhuma institulção } \\
\text { especial }\end{array}$ \\
\hline ATMOSFI:RA & Pode set repressiva & Geralmente suportável & Suportável \\
\hline $\begin{array}{c}\text { MEIO DE } \\
\text { APRENDIZAADO }\end{array}$ & Pré-arranjado & Pré-arranjado & Não arranjado \\
\hline PARES DE ESTUDO & Externamente imposto & Não imposto & Não imposto \\
\hline FREQUÊNCIA & Compulsória & Voluntária & Voluntária \\
\hline CONTEÚIDO & Estruturado & Estruturado & Não estruturado \\
\hline MOTIV^Çヘ̃O & $\begin{array}{l}\text { Tipicamente } \\
\text { extrínseco }\end{array}$ & $\begin{array}{l}\text { Tipicamente } \\
\text { intrinseco }\end{array}$ & Principalmente intrinseco \\
\hline $\begin{array}{c}\text { RESPONSÁ VEL PELO } \\
\text { ENSINO }\end{array}$ & Professor & Professor/Estudantes & Estudantes \\
\hline TAXAÇÃO & Incluída e esperada & Esperada & Nenhuma \\
\hline
\end{tabular}

Ao se analisar o quadro, fica evidente que a distinção entre o não formal e o informal é tênue, pois, muitos atributos são similares, razão pela qual, muitas vezes, as atividades, pertinentes àquelas categorias, são designadas como não formal informal. Esta, talvez, seja a razão para o título genérico formas não convencionais de educação.

Pensando na modalidade Clube de Ciências e Cultura e na forma como este tem sido desenvolvido, em seus projetos e propostas, percebemos que ele se aproxima muito da abordagem não formal, embora tenha característica outras, que the conferem peculiaridades e que serão apresentadas e discutidas no capitulo referente. 


\subsection{As Características Gerais de um Clube de Ciências e Cultura}

Convém que seja feita, neste momento, uma breve caracterização do que '́ o Clube e sua atuação, como forma de subsidiar a leitura desta proposta. Posteriormente, no capítulo referente aos resultados, ele será extensamente explicitado e descrito, sob o título O Clube esperado

O Clube é um espaço onde crianças e jovens estão agrupados e sob orientação, participando de atividades preparadas e estruturadas a partir do interesse e curiosidade comuns. Organizados, os educandos estabelecem uma dinâmica coletiva, executando tarefas, dialogando e compartilhando idéias e experiências, buscando informações e construindo conhecimentos

Os encontros são permanentes e sistemáticos, idealmente semanais. Neles, diálogos e discussões, entre os educandos e entre este e o(s) educador(es), permitem a estruturação de pequenos "projetos de pesquisa", que serão desenvolvidos segundo o ritmo e a produção do grupo. Nesta posição, o professor orientador assume também outros papéis, encorajando, facilitando e preparando o ambiente para o aprendizado.

Nesse ambiente, os alunos são estimulados a atuarem de maneira ativa, buscando soluções para questões e interesses, muitos dos quais levantados pelos próprios educandos. Eles são encorajados a explicitar seus modos de pensar, sobre fatos e

fenômenos, testar suas idéias, e se encaminhar na busca de respostas. À medida que as etapas se processam, os participantes vão produzindo, relacionando e comparando os conhecimentos, dentro de uma abordagem sócio-construtivista. (BENLLOCH, 1984; MIZUKAMI, 1986). 
De maneira didática e lúdica, TORRES et al. (1978) explicam as etapas de organização de grupos científicos para jovens estudantes. Os referidos autores apresentam as formas de estabelecimento das relações de convivência no trabalho científico, tratam das questões pertinentes à metodologia, bem como das sugestões de temas, permitindo conhecer e explorar o mundo cientifico e tecnológico

Para a saúde, metodologia similar é proposta por BARTHES e VAN DER VYNCHT (1998), através de uma abordagem de solução de problemas, tendo como ponto de partida a observação, seguida de questionamento. Os autores consideram que esta forma conduz ao favorecimento de subsídios de conhecimentos e habilidades, em um processo continuado

GREEN et al. (1980) propõem para a educação em saúde o uso de várias estratégias didáticas. As diferentes categorias apresentadas estão estruturadas segundo objetivos definidos, as diversas fases do processo educacional e os educandos envolvidos. Muitas daquelas estratégias estão presentes em metodologias participativas, utilizadas em educação popular (VIANNA, 1986; IMDEC, 1988; WALLERSTEIN \& SANCHEZMERKI, 1994). Há que se considerar que cada estratégia apresenta um potencial educativo diferente, permitindo que se desenvolvam diferentes habilidades e atitudes.

A proposta educativa centrada em projeto de ensino vem sendo reconhecida e defendida, por vários autores, como vantajosa do ponto de vista educacional e pedagógico (KRASILCHIK, 1986; HERNÁNDEZ \& VENTURA, 1998; HERNÁNDEZ, 1998). HERNÁNDEZ e seu colaborador apontam que a preparação de projetos é também uma forma de organizar conhecimentos, pois permite a possibilidade de alternativas de busca, relacionando procedimentos, dando sentido e funcionalidade ao que se deve aprender e mostrando o sentido de memorização compreensiva. 
Para o clube percebe-se que, além do tempo disponível para o desenvolvimento dos trabalhos e visão total do processo, aspecto este defendido pelos autores acima citados, há convergência e coneç̧ão de interesses, favorecendo a aprendizagem e tornando o conhecimento significativo.

Em publicação preparada a partir do $1^{\circ}$ Forum Estadual de Debates sobre Clubes de Ciências, ocorrido no Rio Grande do Sul, vários autores explicam a importância e objetivos presentes nas propostas de criação de clubes, bem como as etapas necessárias para a implantação destes centros de ensino (DIAS, 1995; RIBEIRO et al., 1995; MARQUES, 1995; COSTA, 1995 e GOMES, 1995).

No Brasil, o IBECC (Instituto Brasileiro de Educação, Ciência e Cultura), instituição vinculada à Unesco, aplicou programas e projetos estimulando a criação, implantação e desenvolvimento de clubes, tanto no estado de São Paulo, como em outras unidades da federação, voltados para o ensino básico e fundamental. Constam de seu banco de dados cerca de 700 clubes presentes nas diversas cidades do país (arquivo de 1990). As ações desenvolvidas pela instituição vêm ocorrendo com apoio de agências governamentais, como o CNPq e a Fapesp. Elas promovem treinamentos e assessorias, que visam capacitar professores/educadores para coordenar e orientar os trabalhos em seus clubes.

\section{A Educação e a Promoção em Saúde}

A busca de concepções mais igualitárias e uma educação voltada para a construção da cidadania, da ética, dos direitos humanos e à valorização da cultura, tem sido a proposta principal de órgãos oficiais de educação, visualizados através de novos programas e metodologias, tanto no Brasil como em outros países. Dessas propostas desenham-se novos modelos educacionais, podendo ser reconhecidas nos denominados 
Temas Transversais (LUCINI, 1994; REYZÁBAL e SANZ, 1995), e nas publicações oficiais como os PARÂMETROS CURRICULARES NACIONAIS (PCNs, 1997).

A transversalidade não significa criar novas áreas ou disciplinas, mas refere-se aos conteúdos relacionados a problemas atuais, envolvendo atitudes e valores. Ela busca uma perspectiva humanizadora e ética na formação dos educandos, com a construção da cidadania, impregnando e dando nova dimensão aos componentes curriculares, através de temas emergentes entre os quais estão saúde e meio ambiente (MOYANO, 1997; PCN, 1997 a; b; c). Segundo MOYANO (op. cit.) esta transversalidade pode ser entendida sob várias óticas:

- transversalidade curricular, que se refere aos conteúdos conceituais e atitudinais presentes nas diversas áreas e disciplinas;

- transversalidade institucional, não se limitando ao docente na sala-de-aula, mas com compromisso com todos os membros da comunidade escolar;

- tranversalidade social, referente aos conteúdos relacionados ao cotidiano e não só do espaço escolar.

O tratamento transversal deve estar presente nos projetos educativos e curriculares envolvendo tanto as escolas, como outros centros educativos. Desta forma, nos textos acima citados, é reiterado que a escola não é o único espaço para educar, mas estão previstas novas mediações e novas instituições, redefinindo espaços onde a cidadania pode ser praticada, como forma de superar as desigualdades e a conseqüente exclusão de grande parte da população (MOYANO, 1997; PCN, 1997 a).

Para muitos estudiosos, o acesso à educação é reconhecido como forma de emancipação, diminuindo a ignorância, a pobreza, a exploração e outros aspectos sociais, 
tirando as pessoas da marginalidade e colocando-as no contexto de vida local e nacional (SAVIANI, 1986; FREIRE, 1996; OPAS/OMS, 1996).

A educação, em especial, a educação voltada para a saúde, tem sido motivo de profunda reflexão por parte de especialistas e técnicos. Documentos de instituições e agências de saúde e educação, nacionais e internacionais, como Ministérios e Secretarias e a Organização Mundial da Saúde (OMS), apontam a educação e promoção da saúde, essa um direito do cidadão, como um dos pré-requisitos básicos para a melhoria da qualidade de vida das pessoas e comunidades (CARTA DE OTTAWA, 1986; MINISTÉRIO DA SAÚDE, 1996).

As concepções de educação e promoção em saúde têm sido intensamente apresentadas e discutidas por inúmeros autores e documentos (CARTA DE OTTAWA, 1986; PILON, 1986; FOCESI, 1993; CANDEIAS, 1997; SOUSA, 2000). Neste momento é preciso mencionar que aqueles termos não são sinônimos e que a promoção é mais ampla e abarca a educação, convocando um compromisso não só individual, mas principalmente da coletividade, visando a um objetivo comum "Saúde para todos" (OMS, 1986; DHILLON e PHILIP, 1992). É preciso lembrar que o mesmo princípio é preconizado para a educação pela UNESCO: "Educação para todos" ( BARTON, 1998). CANDEIAS (1997) explica em seu texto que as ações da promoção em saúde são bastante distintas, podendo ocorrer fora do espaço tradicional para programas de saúde, em intervenção social.

As conferências internacionais, voltadas para a saúde e realizadas em Ottawa (1986), Adelaide (1988), Sundsvall (1991), Bogotá (1992) e Jacarta (1997), geraram documentos colocando a Promoção da Saúde como um modelo mais visível e abrangente para o pleno desenvolvimento das nações. Esse modelo supera a condição curativa, deslocando o foco para a relação saúde e sociedade - na qual como afirma a Carta de Ottawa (1986), entre os campos de ação estão a criação de ambientes 
favoráveis, o reforço à ação comunitária e o desenvolvimento de habilidades pessoais (grifos nosso), além das políticas públicas e dos sistemas e serviços de saúde.

Os documentos, acima mencionados, entendem que a democratização das informações, com a apropriação de conhecimentos por um número cada vez maior de pessoas, as capacitariam para atuar como individuos, nas questões pessoais e sociais, pertinentes portanto ao ser biológico e social, e nas relações com o ambiente. Desta forma estariam participando $\mathrm{e}$ intervindo ativamente em seu contexto de realidade especifica ( MINISTÉRIO DA SAÚDE, 1996). A CARTA DE OTTAWA (1986), presente nas publicações do Ministério da Saúde, explicita a necessidade de capacitar o individuo e o grupo para atuar na melhoria da sua qualidade de vida e saúde, incluindo uma maior participação no controle do processo e salienta a importância da participação, justificando que para atingir um estado completo de bem-estar fisico, mental e social, os individuos e grupos devem saber identificar aspirações, satisfazer as necessidades e modificar favoravelmente o meio ambiente.

Desta forma, as estratégias da promoção da saúde exigem programas que busquem reduzir as desigualdades sociais, visando promover a saúde como contribuição para a melhoria da qualidade de vida. Para PILON (1986), a educação é parte integrante da qualidade de vida. Os programas devem permitir que a população tenha acesso não só ao conhecimento mas também, às conquistas da ciência. Para tanto, é necessária uma mobilização em várias dimensões: da esfera política às menores parcelas da comunidade (FOCESI, 1993).

MINKLER (1989, citado por SOUSA, 2000, p.155) preconiza a ação na dimensão da promoção em saúde, afirmando que as evidências têm demonstrado, cada vez mais, que a classe social é um dos maiores, ou talvez o maior, fatores de risco para as doenças. A sua argumentação, para atuar na promoção da saúde, está no fato de considerar a ação voltada para os niveis tanto individual, quanto social. 
Os modelos de ação educativa, inicialmente assentados na dimensão médica, com visão técnico/ científica e voltada para os estilos de vida do indivíduo, foram redefinidos segundo novos paradigmas. Nesses, os esforços estão centrados, fundamentalmente, no desenvolvimento e fortalecimento do individuo e sua comunidade, em dimensão sóciocultural (STOTZ, 1993; CERQUEIRA, 1996; CANDEIAS, 1997). CERQUEIRA (op. cit.) menciona promoção de saúde comunitária. A proposta passa, certamente, pelo acesso aos conhecimentos científicos e tecnológicos e envolve um conjunto de habilidades e destrezas. Dentro do processo operativo, a autora prioriza, entre os vários fatores, os valores, os conhecimentos, as atitudes e as práticas individuais e coletivas, que interferem no entorno, nas condições de vida, na saúde e no bem-estar.

Atores em seu contexto, as pessoas em geral, tais como homens e mulheres, crianças e jovens, devem ser capazes de intervir, em condições de eqüidade, influenciando nos fatores de desenvolvimento social e pessoal, interferindo na qualidade de vida. Para identificar aspirações, satisfazer necessidades, modificar favoravelmente o meio ambiente e ter maior participação, como preconiza a CARTA DE OTTAWA (1986), é preciso que esses sujeitos estejam preparados. Documentos apontam a necessidade coordenada de instituições públicas e privadas atuarem na capacitação individual e coletiva de educandos.

Assentado nessas idéias, há um estímulo crescente por parte de muitas instituições, representadas, entre outras, pela UNESCO, ONGs, universidades públicas e privadas, para o desenvolvimento de programas e currículos voltados para a educação básica e educação em saúde, congregando educandos de várias idades, em especial crianças e adolescentes, pertencentes à famílias de baixa renda. Estas experiências devem conter na sua estrutura, a educação e promoção para a saúde, ajudando na formação e fortalecimento dos educandos, permitindo a melhoria de vida dos participantes e de seus familiares. Neste sentido, é preciso citar o artigo A nova interface universidade- 
sociedade, de Paulo Costa Lima (2000), onde o referido educador convoca, baseado na LDB da Educação, para uma maior interação entre a extensão e a graduação, no sentido de que os graduandos das universidades se envolvam em trabalhos participativos, voltados para a comunidade, como forma não só de compartilhar conhecimento, mas como ferramenta de transformação, saindo do que o autor chama de pedagogia do alheamento e atuando em novos espaços, com potencialidades de ensino $e$ aprendizagem.

Os documentos aqui citados apontam a necessidade de parcerias entre instituições, para que a atuação se estabeleça e se desenvolva, e entre elas estão as educacionais. Os textos mostram uma preocupação crescente com a condição de eqüidade e com o ambiente. Para a América Latina, a CARTA DE BOGOTÁ (1992) chama a atenção, em relação ao ambiente, para a grande deterioração da qualidade de vida das populações, com repercussão séria na saúde. Assim, a promoção da saúde tem que vencer um desafio enorme para superar as questões nas diversas instâncias políticas, econômica, educacional, social e cultural, a fim de alcançar a eqüidade, melhorar a qualidade de vida e permitir uma relação mais harmoniosa com o ambiente. Neste momento, é fundamental que a promoção e a educação em saúde atuem de maneira vigorosa para que se estabeleça a importância da participação ativa das pessoas na modificação das condições sanitárias e na maneira de viver, indutoras da constituição de uma cultura da saúde. Neste sentido, a divulgação de informações e a promoção do conhecimento constituem valiosos instrumentos para a participação e para a mudança nos estilos de vida das comunidades.

Considerando promoção em saúde, tendo como pano de fundo as propostas contidas nos documentos, a noção de "empowerment" está subjacente e permeando as ações. LĖFREVE (1998) usa o termo como fortalecimento das populações e AUGOYARD e RENAUD (1998) entendem como habilitação, tomada de controle, responsabilidade e subjetivação. De qualquer forma, para estes autores, é conferir à 
população meios de exercer controle sobre a própria saúde (ROBERTSON e MINKLER, 1994). Para tanto, é preciso que os indivíduos estejam submetidos à condições, de modo que possam receber informações e enfrentar dificuldades, adquirindo aptidões. Isto é possível com a presença de políticas públicas e a organização e participação da comunidade. Para AUGOYARD e RENAUD (op. cit.) o "empowerment" representa precisamente a capacidade de pessoas marginalizadas terem em suas mãos a força e fazer avançar suas causas, gerando um sentindo politico de controle sobre sua vida. Eles apontam que este talvez seja o melhor indicador de bemestar, pois permitem que as percepções subjetivas aflorem e que realmente exerça controle sobre os serviços que lhe são oferecidos. Isso decorre do processo de promoção em saúde, que deve ser vista como uma resposta a um movimento social que busca novos conhecimentos e que pode ser iniciado mesmo com jovens (WALLERSTEIN, 1994).

Ao definir alfabetização em saúde, o Glossário da OMS (1998), afirma ser este um fator crítico para o "empowerment", que por sua vez é dependente de outras formas de alfabetização. Pode-se entender que a alfabetização incompleta ou mal conduzida reflete na saúde, uma vez que ficam comprometidas as habilidades cognitivas e sociais, limitando o desenvolvimento do indivíduo tanto no âmbito pessoal, como social e cultural. Mas, qual o significado de alfabetização?

\subsection{A Alfabetização em Ciências e Saúde}

Ao definir este estudo, sem dúvida, é preciso refletir a respeito do que se refere a alfabetização em Ciências e Saúde. Se buscarmos a definição para o termo alfabetização, em dicionário (FERREIRA, 1986), encontraremos entre outras, as seguintes interpretações: ensinar a ler e dar instrução primária. São um bom começo para a reflexão. 
Sem dúvida, a concepção passa pela dimensão dos propósitos e objetivos do próprio ensino. Tradicionalmente, ao ensinar Ciências, o que se pretende é a formação de conceitos, sua compreensão e interiorização. MAARSCHALK (1988) chama a atenção para o lançamento do Sputnik, pelos russos na década de 50, que motivou uma série de publicações voltadas para as mudanças do ensino e para a importância da alfabetização científica, quando o conceito foi explicitado e incorporado na lista de objetivos do ensino daquela disciplina

MAARSCHALK (1988) cita RENNER e STAFFORD (1979, p.135), KARPLUS (1964, p.135), GUTHRIE (1985, p.135), MELETTE (1980, p.135), FINSON e ENOCHS (1985,p.135) e BYERLY (1985, p. 135) para discutir e analisar o conceito, explicando que para iniciar, este poderia ser colocado como a habilidade de relacionar os conteúdos com os processos da Ciência. Na sua reflexão, ele avança mostrando que a concepção envolve várias categorias de objetivos e pode ser vista sob várias óticas, como o da informação, que define ser a pessoa capaz de resgatar, usar e comunicar uma informação cientifica e do trinômio Ciência/Tecnologia/Sociedade, estabelecendo interfaces entre ciência, desenvolvimento e sociedade, apontando que alfabetização ocorreria se uma pessoa soubesse relacionar estas três dimensões.

MAARSCHALK (1998) chama atenção para o papel fundamental desempenhado pelo ensino não-formal/informal na melhoria da alfabetização, comentando sobre o que BRUNNER (1961, p.138) denomina de autonomia auto-compensatória e maximização das condições de questionamento.

KICKBUSCH (1997) em palestra proferida na $4^{a}$ Conferência Internacional, em Jacarta, aborda a relevância de programas voltados para a alfabetização em saúde. A autora chama a atenção para a questão das rápidas mudanças que se processam nos conhecimentos relativos à saúde. Novos problemas, novos riscos, novos tratamentos e 
novas maneiras de se manter saudável, havendo, portanto, necessidade de novos aprendizados.

No glossário de PROMOÇÃO EM SAÚDE (1988), o termo aparece como "alfabetismo" em saúde (as aspas são do documento), em inglês health literacy, e o documento conceitua: "alfabetismo" em saide representa as habilidades cognitivas e sociais que determinam a motivação e a habilidade de individuos para terem acesso a compreenderem e utilizarem informações de forma que promovam e mantenham boa saíde.

A partir das considerações acima, podemos chegar à concepção: ser alfabetizado em Ciências e Saúde é estar introduzido no mundo da Ciência e ter habilidades para ler, compreender, escrever, buscar, utilizar e relacionar informações e conhecimentos cientificos, em beneficio próprio e coletivo.

Vários autores discutem as propostas de educação e promoção em saúde, na dimensão do ensino escolar ( KOLBE, 1982; DHILLON e PHILIP, 1992; FOCESI, 1992; YARHAN, 1994), como forma de garantir programas de educação, que melhorem a saúde de crianças e jovens. YARHAN (op. cit.) identifica aspectos que devem ser contemplados nos programas tais como: definição clara dos propósitos, envolvendo estratégias adequadas; conhecimentos relevantes e contextualizados, com o propósito de preparar para as transformações rápidas do mundo; e envolvimento ativo no planejamento, ação e tomada de decisão dos educandos.

Desdobramentos das propostas e metas das conferências têm permitido o desenvolvimento de programas como o proposto pela OPAS (Organização Panamericana de Saúde, 1998) "Escola Promotora da Saúde". Embora o programa esteja voltado para o ensino formal, escolar, ele afirma que a educação e saúde devem se fortalecer mutuamente e que os conhecimentos adquiridos também no ensino informal, não 
estruturado, no âmbito da vida cotidiana, podem atuar de maneira vigorosa para promover a saúde. A Carta de Ottawa (1986) reconhece que a saúde se cria e se vive no dia-a-dia: nos centros de ensino, de trabalho e de recreação. Lla é resultado dos cuidados que cada um dispensa a si próprio e aos outros; da capacidade de tomar decisões e controlar a vida própria, assegurando que a comunidade onde se está inserido ofereça a todos a possibilidade de gozar um bom estado de saude (OPAS, 1998; KICKBUSCH et al., 1998).

Seria ingênuo colocar somente sob a responsabilidade da educação a superação de problemas sociais tão complexos como a diminuição da ignorância, pobreza e exploração, pois como a saúde, aquela instância tem elementos objetivos e subjetivos; coletivos e individuais; públicos e privados, que se interpenetram, tratando-se de dimensões complexas da vida humana. FREIRE (1996) afirma que a educação, mesmo sendo ato político, por si só não determina as transformações sociais. $O$ impacto das ações educativas, com repercussão nas condições de saúde, vai depender de um conjunto de fatores entre os quais estão as condições individuais, do grupo, do ambiente e da realidade sócio-cultural. Tais aspectos não impedem, no entanto, uma relação cooperativa e integrada entre educação e saúde, pois ela traz beneficios como mostram muitos estudos. Há indícios de que adultos e crianças, que apresentam um maior grau de educação, atingem estados mais elevados e melhores de vida e saúde, tendo acesso, assim, aos recursos, bens e serviços (OPAS, 1998).

YARHAM (1994) afirma que programas de saúde preparados e aplicados em periodos de crise, em geral, não dão resultados satisfatórios, sendo que os trabalhos preventivos são muito mais eficientes.

Para WEARE (1993) a meta central da educação é capacitar as pessoas a serem autônomas. Ser educado é essencialmente ser livre, ter controle da própria vida, ser capaz de pensar racionalmente e logicamente e tomar decisões sem coersão ou medo. 
LEFRÈVE (1998) aponta que educar envolve informar e dialogar, devendo a ação ocorrer dentro de uma proposta educativa informativa e não condutivista. Assim, para este autor, é preciso que a informação seja decodificada, permitindo que o educando conduza, ele próprio, sua vida.

Tais aspectos encontram eco no documento da OPAS (1998), que mostra que a educação, em especial a educação em saúde, ocorre através de um processo que ultrapassa a simples comunicação de informações, mas que seja dialógica, envolvendo a motivação, habilidades e confiança necessárias. O referido documento chama a atenção, relacionando a melhoria da aprendizagem com a melhoria da saúde. Criança com saúde aprende melhor. Neste sentido NAKAJIMA (1992) afirma que, a educação prepara a criança tornando-a autoconfiante, saudável e cidadão produtivo. Educar as crianças para a saúde deveria ser prioridade máxima, não só do ponto de vista da saúde, mas da própria educação, pois para aprender efetivamente, as crianças necessitam estar em boas condições de saúde.

Crianças, pré-escolares e escolares, são capazes de adquirir conhecimentos e desenvolver comportamentos. Assim, escolas e outras agências de ensino são ideais, facilitando e propiciando a criação e desenvolvimento de uma consciência sobre a importância da saúde física e mental, permitindo a aquisição de valores, atitudes, habilidades $\epsilon$ destrezas, para que possam, elas mesmas, cuidar da saúde e ter uma convivência harmônica.

O documento da World Health Organization (DHILLON, PHILIP, WHO, 1992), ao referir-se à educação em saúde no âmbito escolar, chama a atenção para a relação inseparável entre saúde e educação e relaciona propósitos importantes, na construção de currículos, para a atuação de programas em saúde: 
- saude do ponto de vista holístico, estabelecendo inter-relações entre problemas $\mathrm{e}$ suas causas, dentro de contextos ambientais;

- oportunidades educativas para saude, considerando ambientes formais e informais, currículos básicos e inovadores e a pedagogia. Podendo ocorrer nos serviços e espaços disponiveis dentro e fora da escola;

- veiculação de mensagens harmônicas, considerando fontes que influenciam os estudantes;

- fortalecimento de crianças e jovens, de modo a conduzi-los e promovê-los para uma vida saudável.

Desta maneira, as ações da promoção e educação em saúde devem permitir melhorias da condição de vida do educando, de seus familiares e do seu entorno, ações estas que devem ser compativeis e adequadamente estruturadas, segundo a cultura, valores e crenças dos envolvidos. Esta melhoria estabelece, por extensão, uma relação com a prática pedagógica, que deve ser orientada e conduzida por um educador preparado para desenvolvê-la. Ao analisar a educação em saúde para crianças, LOUREIRO (1996) faz considerações acerca do educador e seu papel, advogando a necessidade de um contínuo aperfeiçoamento, além do conhecimento dos participantes, seu ambiente e problemas, chamando atenção para o compromisso do mesmo com a prática educativa e suas estratégias e aproveitando oportunidades de vivência em saúde, segundo a realidade e necessidades locais. Assim, a educação em saúde deve contemplar, como aponta KOLBE (1996), objetivos tais como:

- aumento da compreensão sobre a filosofía e ciência da saúde; 
- aumento da competência dos indivíduos para tomar decisões a respeito dos comportamentos pessoais, que influem na saúde;

- aumento das habilidades necessárias para que os individuos adotem comportamentos que favoreçam à saíde;

- estímulos que conduzam a comportamentos saudáveis;

- aumento das habilidades para melhorar a saúde da familia e comunidade.

No Brasil, programas educacionais para jovens e crianças enfocando a saúde, vinculados ao currículo formal, escolar, atingem muitas vezes classes sociais mais favorecidas. São escassas e incipientes as experiências não-formais contínuas, voltadas para educandos de baixa renda, completando a educação formal. Essas, quando presentes, carecem de uma avaliação mais sistemática, para verificar sua real contribuição. Assim sendo, este estudo se propõe a buscar entendimento e respostas às questões relativas à uma intervenção educacional, estruturada a partir de um modelo de ensino não-formal, aplicado em um Centro da Juventude, que congrega educandos moradores de uma favela, em São Paulo.

Neste estudo pretende-se identificar as possibilidades e verificar a extensão da ação educativa de um Clube de Ciências e Cultura na formação de crianças, tendo como foco os temas pertinentes às áreas de Ciências e Saúde.

\section{O Objeto de Estudo}

No Brasil, estudos sobre as formas não convencionais de educação têm merecido inúmeras pesquisas, em especial sobre a alfabetização de adultos, o papel da mídia e da 
familia. Especificamente voltadas para esses clubes, quase nenhum estudo foi realizado, embora a modalidade de ensino não-formal/informal seja popular nos meios educativos.

Muitos clubes estão vinculados a escolas e estes têm fornecido subsídios, na forma de estudos e pesquisas, para outras atividades escolares como feiras de Ciências; Semanas e Atividades Culturais; Estudo do Meio e de Educação Ambiental. Em geral, eles são subvencionados por seus participantes, associações de pais e pela própria escola e coordenados por professores da instituição. Seu objetivo maior é dar suporte ao ensino formal. Seus participantes são congregados voluntariamente através de divulgação, estabelecendo compromissos participativos dentro dos projetos ou subprojetos, produzindo trabalhos de caráter cientifico e cultural.

Outras variações têm ocorrido com a presença de clubes associados à instituições religiosas, prefeituras e centros da juventude, atendendo não só às crianças, mas também adultos. com programas voltados para o desenvolvimento de profissões e especializações.

MAIOCCHI (1995), integrante da COPAE AL (Coordenação Para Atividades Extra-escolares para a América Latina), afirma que esse tipo de educação permite utilizar - tempo livre das crianças, que estão vinculadas aos mais diversos subsistemas educativos: pré- escolar, fundamental, médio, técnico, profissionalizante e magistério, criando uma outra opção frente às demandas educativas e sociais.

Desta forma, além dos objetivos pedagógicos, o clube apresenta objetivos de ordem social e pessoal, que acabam por estabelecer ações dinâmicas, lembrando, como aponta DIAS (1995), qual alguns programas dão oportunidade de encontro e promoção de profissões. Referências sobre a importância e o papel desempenhado por clubes estão presentes, principalmente em publicações da UNESCO (1989), que têm procurado incentivar o uso desse modelo para trabalhos educacionais 
Para a área de saúde, poucas publicações contemplando processos educativos relacionados a clubes foram encontradas. Entre elas estão os trabalhos de KATSHA e WATTS (1994), que apresentam a descrição de um Clube de Verão, dando ênfase ao modelo, como forma de atingir um grande número de educandos, em tempo curto. Os autores explicam que tal forma de trabalho é diferenciada e ocorre em atmosfera relaxada e informal, favorecendo a interação entre o professor e os educandos. Nesse clube foram tratados temas referentes a educação ambiental, voltados para crianças de 10 a 12 anos, no Egito. Outro trabalho foi o de DIAS (1995) relatando a atuação de um Clube de Ciências, presente em uma escola estadual em Porto Alegre, RS. Este desenvolveu um projeto de "Educação e Saúde Oral" para crianças das séries iniciais do ensino fundamental, conduzido por alunos do magistério.

Ao se estudar a ação do clube na educação e promoção de conceitos pertinentes à saúde, pretendeu-se não só aplicar o modelo Clube de Ciências, mas lançar um olhar reflexivo, mais profundo, procurando compreender e apreender sua identidade e representação, além de seus problemas, limites determinantes e interferências segundo o contexto. A busca de respostas para as questões : Como se estrutura o Clube? Qual a sua forma? Quem são seus participantes? Como interfere na formação das crianças? Qual a extensão de sua ação? e Quais são as respostas e mudanças dos participantes frente ao trabalho? nos permitiram uma aproximação crítica e analítica do objeto de estudo.

\section{Os Objetivos Gerais e Específicos}

Este estudo visa analisar o desempenho de um Clube de Ciências e Cultura como alternativa de ensino voltada para a promoção e educação em saúde.

Sob esta perspectiva, especificamente, o estudo propõe-se a 
i. planejar e implantar um Clube de Ciências e Cultura em uma comunidade carente;

ii. acompanhar e caracterizar o processo de estruturação do Clube;

iii. caracterizar seus participantes, identificando suas expectativas e interesses frente ao trabalho do Clube;

iv. avaliar as ações do Clube e verificar seu potencial e eficácia no processo de ensino e aprendizagem de ciências e saúde através das respostas e produtos dos educandos;

v. verificar a extensão da intervenção não formal no ensino formal, identificando e caracterizando possíveis apropriações de habilidades e conhecimento;

vi. obter subsídios para orientar novas ações em estratégias educativas similares. 

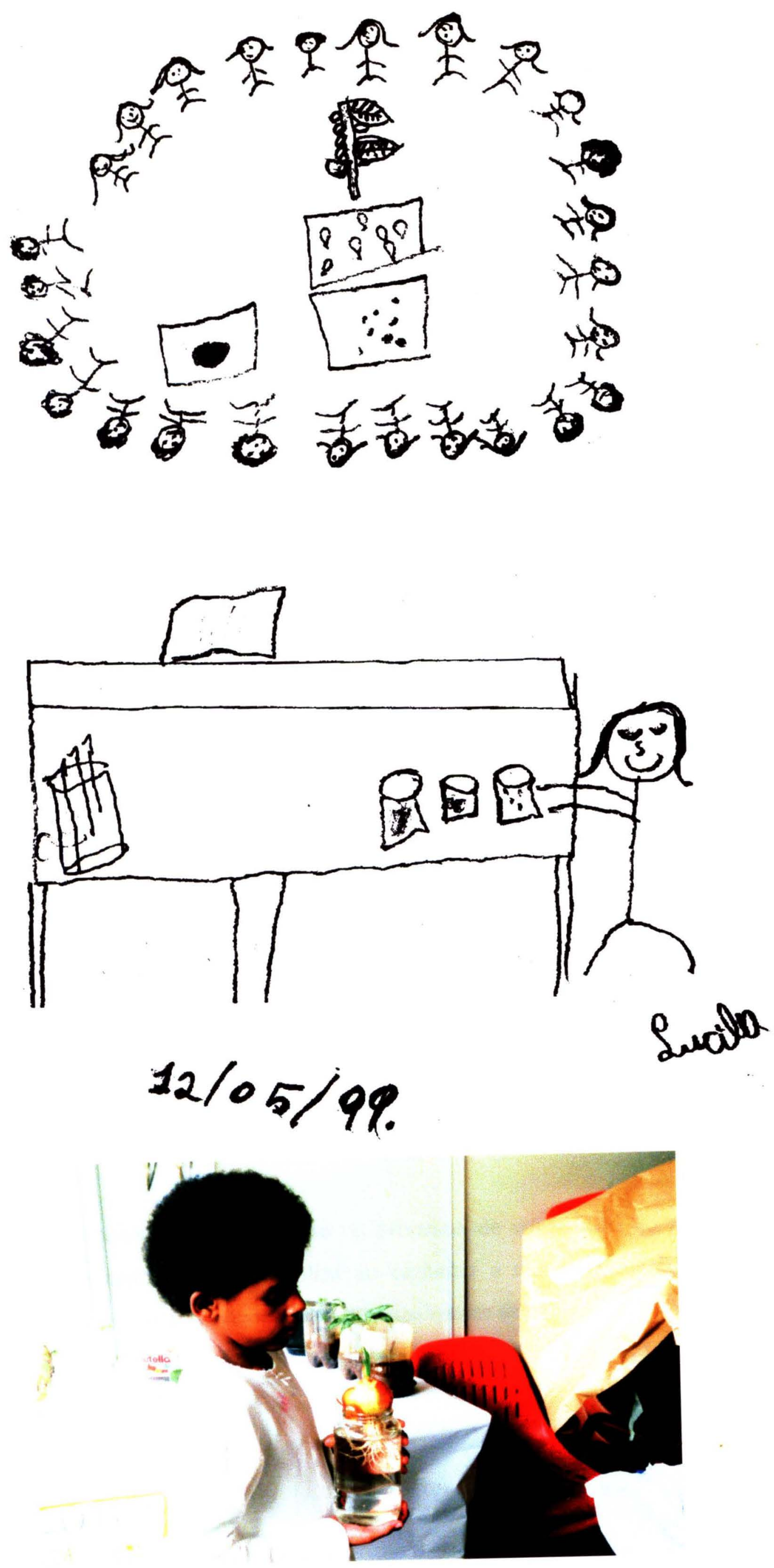


\section{II - MÉTODOS E DISCUSSÃO METODOLÓGICA}

\section{A Aproximaç̃o}

Percepções de caráter subjetivo e representacional, estruturadas a partir das experiências vividas anteriormente pela pesquisadora, constituíram-se em um conjunto de referências. Ele, composto na sua essência de experiências sistematizadas, rotinas e relações educativas socializadas regulares, permitiu prever o fazer e o pensar dos envolvidos na ação pedagógica do clube e converteu-se em um modelo possível de ser aplicado para o desenvolvimento de programas de educação e promoção em saúde, considerados para educandos em centros da juventude e em outros espaços educativos não-formais

Ao circunscrever os limites do problema e definir e organizar os objetivos, o pensamento voltou-se para a estruturação da metodologia. Para tanto, as vivências e percepções anteriores forneceram referências para a definição de um método que contemplasse a pesquisa, permitindo o estudo acerca das questões pertinentes à atuação do clube e de seus participantes.

Tentou-se definir os procedimentos a priori, mas ao longo dos quase 15 meses de levantamentos, dentro de um processo essencialmente ativo, verificou-se que a estrutura constituída pelo espaço e ações apresentava uma dinâmica própria, levando a uma construção gradativa do método.

Cabe neste momento explicitar que o processo de construção do método, aqui apresentado como metodologia, se aplica ao caminho e aos instrumentos usados na pesquisa, envolvendo não só as ações, mas principalmente as análises e críticas presentes, para apresentar a realidade. Esta foi revelada através da observação, descrição e 
interpretação dos conhecimentos produzidos, permitindo estabelecer e estruturar teorias a partir da qualidade, consistência e originalidade das constatações, cujo grau de fidedignidade orientou as respostas às questões iniciais e contribuiu para o clareamento e elucidação das questões definidas no projeto.

Ao se propor a pesquisar sobre a estruturação e atuação educativa de um Clube de Ciência e Cultura e a observar a sua ação através de seus participantes, não havia dúvida de que o caminho e os instrumentos utilizados estariam inseridos em uma pesquisa qualitativa. SANTOS FILHO (1997) afirma que essa metodologia permite a compreensão de atividade em dois niveis: um direto ou imediato e outro mais profundo, visando conhecer a natureza e o significado da ação pelo individuo. $\mathrm{O}$ autor cita TAYLOR e BOGDAN (1984, p.39) para explicar que esse tipo de pesquisa tem seu foco na compreensão ou interpretação do fenômeno social, com base nas perspectivas dos atores por meio da participação em suas vidas.

Para PATTON (1986), citado por ALVES-MAZZOTTI (1999, p.131), a principal característica desta pesquisa reside na sua tradição interpretativa, ou seja que as pessoas agem em função de suas crenças, percepções, sentimento e valores, tendo seu comportamento um sentido, um significado que precisa ser desvelado.

Em relação à pesquisa qualitativa, LÜDKE e ANDRÉ (1986) afirmam que esta abordagem tem no pesquisador seu instrumento principal, estando ele em contato direto e prolongado com o objeto a ser investigado, instigado pelo processo, descrevendo e dando significado às coisas. Esses aspectos subsidiam teoricamente a pesquisa, permitindo a escolha de fatores e sua interpretação, de modo a entendê-los e verificar sua validade. Como resultado das estratégias metodológicas decorrem descrições detalhadas, citações literais das falas apresentadas pelas pessoas, suas experiências, atitudes, crenças e pensamentos, fragmentos dos documentos, que explicam a dinâmica 
das relações sociais, dentro do que MINAYO (2000) denomina vivencia e cotidianeidade.

Ao buscar na bibliografia as referências para a pesquisa, verificou-se que o estudo proposto e apresentado no capitulo anterior, era inovador e bastante raro na educação e promoção em saúde. Desta forma, não só no campo da educação, mas principalmente no da saúde, esse estado da arte tinha sido pouco contemplado, razão pela qual não foi possível ter a definição de um modelo como referência para estruturar a metodologia. Assim, no desenvolver do trabalho, enfrentou-se o desafio de encontrar maneiras de captar os diferentes significados da estrutura e função do clube e dos sujeitos relacionados, permitindo que o pesquisador se aproximasse de seu objeto de estudo, explicitando sua estrutura e tornando visiveis as necessidades do uso desse modelo de intervenção educativa, de modo a contribuir de maneira mais consistente para o processo de educação e promoção em saúde.

\section{A Estruturação}

Etapa vital do desenvolvimento da pesquisa, a metodologia foi estruturada, essencialmente, a partir de leituras e reflexões sobre os textos de LÜDKE e ANDRÉ (1986), THIOLLENT (1994), GIL (1994 e 1996), MINAYO (1996), ANDRÉ (1997), FAZENDA (1997), SANTOS FILHO e GAMBOA (1997), e LAVILLE e DIONE (1999).

As leituras, tendo como foco a integração entre os campos da saúde e educação, forneceram visibilidade e conhecimento das diversas abordagens aue a sociologia e as humanidades oferecem às investigações. A pesquisa qualitativa, como mostram os autores supracitados, abarca uma gama de doutrinas, cada uma envolvendo pressupostos teóricos, técnicas e estratégias. No entanto, estudos mais detalhados dos textos de 
ANDRÉ (1997) e HOLLANDA (1993) permitiram definir as estratégias de aproximação do objeto, gerando criativamente as linhas norteadoras do trabalho. Para essas linhas optou-se, dentro da análise qualitativa, pela a metodologia da pesquisa-ação.

\subsection{A Opção pela Análise Qualitativa e a Metodologia Pesquisa-Ação}

Ao se definir pelo tema, as perspectivas nos permitiram verificar que este estudo, por suas características, não poderia ser descrito segundo uma abordagem tradicional, uma vez que seus fenômenos não eram quantificáveis, mas obtidos fundamentalmente a partir de uma realidade que seria construida socialmente, segundo contextos individuais e coletivos, com o pesquisador inserido na referida realidade, buscando compreender e interpretar os fatos.

Estudar as estratégias de implantação e desenvolvimento de um programa educacional para um grupo de crianças e, sobretudo, entendê-lo e avaliá-lo, configurou uma situação de "caso singular", cuja possibilidade de generalização e regularidades não poderiam ser estabelecidas. Tal fato, no entanto, não diminui a importância do trabalho, como afirma LAVILLE e DIONNE (1999). Na verdade, a apreensão das generalizações em um contexto e a sua transferência para outros está relacionada à capacidade do leitor ou usuário em perceber semelhanças deste caso com situações similares, por ele vivenciado (LÜDKE e ANDRÉ, 1986).

A reflexão sobre a forma de conduzir a metodologia para analisar o objeto de estudo nos levou novamente aos textos de SANTOS FILHO (1997), LÜDKE e ANDRÉ (1986) e THIOLLENT (1994). O primeiro autor faz uma discussão acerca da falsa controvérsia entre pesquisa quantitativa e qualitativa, indicando comparativamente as premissas estabelecidas entre pesquisador e objeto de estudo, e outras perspectivas tais como: visão de mundo; fatos e valores; objetivos; abordagem; foco; papel do pesquisador 
e critérios de pesquisa. O autor, da mesma forma que MINAYO (2000), aponta que não há necessidade de conflito entre as duas abordagens, mas elas podem ser complementares.

O texto de LÜDKE e ANDRÉ (1986) nos ajudou a definir as linhas diretivas dentro da análise qualitativa. Os autores mencionados baseiam-se em BOGDAN e BIKLEN (1982, p.11-13), definindo um conjunto composto de cinco características nas quais se insere esta pesquisa, e que são apresentadas e brevemente analisadas a seguir:

1. A pesquisa qualitativa tem o ambiente natural como sua fonte direta de dados e o pesquisador como seu principal instrumento.

Isto supõe um intenso e prolongado contato do pesquisador com o ambiente e a situação que está sendo investigada, estudo denominado "naturalístico", onde os fenômenos ocorrem e são influenciados pelo seu contexto.

2. Os dados coletados são predominantemente descritivos.

Para tanto se pressupõe o uso de diferentes estratégias de levantamentos de dados, como forma de subsidiar a afirmação ou esclarecer pontos de vista da realidade.

3. A preocupação com o processo é muito maior do que com o produto.

Assim o pesquisador deve estar atento às manifestações que emanam das atividades, dos procedimentos e das interações cotidianas.

4. O "significado" que as pessoas dão às coisas e à sua vida são focos de atenção especial pelo pesquisador.

Neste sentido busca-se capturar as perspectivas dos participantes sobre as questões focalizadas, que são importantes para entender o dinamismo interno das situações. 
5. A análise dos dados tende a seguir um processo indutivo.

Neste momento não houve a preocupação de estabelecer hipóteses a priori ou comprová-las quando definidas, mas de formar abstrações, que foram se estruturandu e consolidando a partir da análise dos dados, que foram paulatinamente se tornando mais específicos e focados

A análise qualitativa envolve um número variado de métodos e técnicas. Ao se definir por essa abordagem, houve necessidade de se pensar não só na teoria que nos dá a ótica pela qual são analisados os resultados, mas também na viabilidade de operar no trabalho de campo. Portanto, ao determinar a metodologia, foram consideradas não só a referência teórica, mas também aspectos sobre as especificidades do objeto de estudo, além das possibilidades e estratégias de ação, para se obter os dados no campo do conhecimento pesquisado.

Referente à pesquisa-ação, THIOLLENT (1994) em seu texto distingue-a de pesquisa participante e argumenta, exaustivamente, sobre a metodologia apresentando definição, objetivos, suas formas possiveis de ação e pensamento, e valor. $O$ autor afirma que sua configuração depende dos objetivos e contextos, permitindo distinguir diferentes casos ou situações em que pode ser usada. Claraınente menciona a situação cujo objetivo é voltado para a produção de conhecimento que não seja útil apenas para a coletividade, mas aquele que é cotejado nos estudos educacionais, com ênfase em um dos três aspectos: resolução de problemas, tomada de consciência ou produção de conhecimento.

Neste estudo houve a proposta de intervenção sistemática, atuando-se concretamente na organização, aplicação e avaliação de desempenho de programa educacional, envolvendo os sujeitos representados por educandos, freqüentadores de um 
centro da juventude. Tal método, adequado aos propósitos da pesquisa, é apresentado por THIOLLENT (1994) como sendo um tipo de pesquisa com hase empírica, que é concebida e realizada em estreita associação com uma ação ou com a resolução de um problema coletivo e no qual os pesquisadores e participantes representativos da situação ou do problema estão envolvidos de modo cooperativo ou participativo. GIL (1994) caracteriza esta modalidade de pesquisa, especialmente pelo envolvimento entre pesquisador e pesquisado, apontando que a realidade não é fixa e o observador e seus instrumentos desempenham um papel ativo na coleta, análise e interpretação dos dados, o que THIOLLENT (op. cit.) denomina de relatividade observacional.

Ao refletir sobre o texto de THIOLLENT (1994), verifica-se que não há necessariamente um enquadramento rígido segundo suas características mas, como o próprio autor menciona, enquanto linha de pesquisa é associada à diversas formas de ação por parte das pessoas ou grupos implicados no problema sob observação.

Para as ações de cunho cientifico utilizou-se de diferentes técnicas metodológicas e fontes variadas que forneceram os dados descritivos, de identificação e compreensão do cenário do clube e dos sujeitos envolvidos, diretos e indiretos, tais como crianças, diretora, monitora e professores do ensino formal, que serão explicitados em item apropriado, neste capítulo

\section{O Controle da Subjetividade e o Rigor Científico}

Desde o início do trabalho de campo houve uma preocupação, na questão metodológica, com o rigor científico. Na relação com os observados, inserida ativamente em todo o cenário e nas ações estudadas, não foi simples evitar a questão da subjetividade, tão implicitamente presente. 
É preciso lembrar a necessidade do distanciamento do objeto estudado, para fugir ao senso comum e aos preconceitos e poder enxergar a realidade sob outros prismas. ANDRÉ (1997) menciona esta questão em seu texto, chamando a atenção para o que denomina de "estranhamento". Esse é explicado como uma necessidade constante de atitude de policiamento para transformar ofamiliar em estranho. Para tal, é preciso um esforço para romper e ir além do aparente, "enxergando" cada vez mais, tentando vencer o obstáculo do processo naturalmente seletivo da observação. Para alcançar tal propósito, a autora sugere discussões grupais, dentro de um processo coletivo de trabalho.

\section{Os Procedimentos Metodológicos e suas Etapas}

A seguir estão apresentados os procedimentos efetuados e suas respectivas etapas. Neles estão explicitados, entre outros aspectos, as características do local de estudo e dos participantes, bem como as estratégias metodológicas definidas para levantar os dados no trabalho de campo.

\subsection{O Local de Estudo e seus Participantes}

O vínculo profissional que levou ao desenvolvimento do programa iniciou-se a partir da ação entre a pesquisadora, interessada na condução da pesquisa, e a instituição escolhida, que acolheu o programa. Esse vínculo, explicitado verbalmente, estabeleceu em uma outra dimensão a relação ensinante-aprendentes, que se caracterizou pela interação entre a educadora, responsável pelo programa educativo, e por outro lado, os educandos, crianças que participaram do programa de ensino. Desta forma, o trabalho de campo gerou ações em duas dimensões interelacionadas, científica e 
pedagógico/educativa, com a participação ativa da pesquisadora na organização e condução das atividades do clube e na estruturação da pesquisa.

O Centro da Juventude (CJ) Santa Cruz, local onde foi implantado o programa, está situado junto à Paróquia São José do Jaguaré, à R. Bartolomeu de Ribeira, 33, no Bairro Vila Nova Jaguaré (SP). O Centro funciona como referência para outras áreas da região como Santa Luzia, Lealdade e Nossa Senhora Aparecida. Em relação ao trabalho com os jovens e crianças, a instituição tem como objetivos principais fazer o acompanhamento escolar e familiar; fornecer alimentação e promover atividades educacionais.

O CJ funciona em galpões especialmente construidos pela paróquia para o atendimento comunitário e está sob administração e condução exercidas pela Congregação Santa Cruz. Essa instituição educativa é responsável pela execução e manutenção, bem como fornecimento de parte dos recursos para os vários projetos educativos e sociais, atendendo diferentes grupos de crianças e adultos. A instituição tem ainda convênio com a prefeitura, recebendo subvenção para alimentação, recursos humanos, gastos com manutenção e material pedagógico.

Especificamente o CJ, sob a direção administrativa e pedagógica da professora Josely Alzemar Mateus Fernandes, atende um total de 135 crianças (apenas 2 não pertencem à favela), de 7 a 14 anos e 11 meses, em seus diversos programas. Além do Clube de Ciências, outros programas estão sendo aplicados tais como : acompanhamento psico-pedagógico e psicológico; artes cênicas; artes plásticas; grupos de inglês; atendimento e reforço em alfabetização e trabalhos com raciocínio lógico. Há uma proposta voltada para a implantação de um programa de classes de aceleração para a alfabetização, semelhante ao programa proposto pela Secretaria de Educação do Estado de São Paulo, para sua rede de ensino. 
No $\mathrm{CJ}$, quanto à saúde e alimentação, as crianças são também assistidas. As que apresentam problemas de saúde são encaminhadas ao Hospital Universitário, na USP, ou ao Posto de Saúde do bairro. Todas as crianças recebem duas das principais refeições, almoço e/ou café da manhã e lanche.

Para participar do $\mathrm{CJ}$, a criança deve estar freqüentando a escola, o que significa permanecer naquela instituição em horário alternado ao seu período escolar. Isso permite que, participando das atividades do centro nos seus mais diversos programas, a criança além de receber alimentos, seja educada e tenha convivência social com outras crianças, estando tutelada no seu horário livre.

\subsection{O Período e o Tema a Ser Desenvolvido}

Nos vários contatos da pesquisadora com o $\mathrm{CJ}$, a instituição se mostrou sempre muito interessada pelo tipo de programa que se pretendia implantar (Anexo 1). Por ocasião da apresentação final do projeto, a direção sugeriu que o trabalho fosse dirigido a um grupo de crianças que freqüentavam o centro no período da manhã. Os contatos definiram também o horário e dia da semana para os encontros. Estes seriam semanais, às quartas feiras, das $8: 30 \mathrm{~h}$ às $10: 30 \mathrm{~h}$.

Neste momento, também foi solicitado que os trabalhos abordassem o eixo temático Alimentos e Nutrição e que fosse considerada a possibilidade de implantar uma pequena horta no local. Tal sugestão, segundo justificativa apresentada, devia-se ao fato de que as crianças, na sua maioria originárias de famílias vindas do nordeste, tinham muita dificuldade em aceitar refeições que usassem verduras e legumes na sua preparação. 


\subsection{As Crianças e as Implicações Éticas}

As trinta e duas (32) crianças selecionadas para o trabalho, com idades entre 7 e 10 anos e 11 meses, eram todas provenientes da favela Vila Nova Jaguaré. Do total, vinte e uma (21) eram meninas e onze (11) eram meninos, todos estudantes. Vinte e cirico crianças (25) freqüentavam a Escola Estadual João Cruz Costa, localizada em uma das ruas que dá acesso à favela. As outras cinco crianças estavam nas Escolas Municipais de Ensino Infantil, Esperidião Rosa e Henrique Dumont (Anexo 2).

Aspecto importante desta etapa foi a preparação dos Termos de Consentimento, documento exigido pela Comissão de Ética da Faculdade de Saúde Pública, a serem enviados aos pais, para que permitissem a participação de seus filhos nas atividades do clube e para que pudessem ser entrevistados pela pesquisadora. Estes termos foram aplicados tão logo foram iniciados os trabalhos, na fase exploratória (vide exemplo no Anexo 3).

Com relação à ética, PRIDMORE (1996) salienta que ter as crianças como “parceiras” na pesquisa demanda não só o respeito a elas como cidadãos, com direitos e responsabilidades frente ao conhecimento e à saúde mas, principalmente, à necessidade de desenvolver formas diferenciadas de aproximação, de modo que se possa compreender como elas percebem o mundo. Há ainda que se considerar razões éticas e humanistas ao usar propostas centradas na criança, pois elas expõem seus modos de ver e suas crenças

\subsection{A Fase Exploratória no Trabalho de Campo}

Convocar as crianças para participar da pesquisa significa reconhecer os cuidados e limitações que devem estar presentes. Eles residiram no "consentimento" da própria criança pela apropriação de sua informação e uso de seus dados na pesquisa. Para tanto, 
alem das explicações necessárias e referentes ao clube, foi preciso explicitar os objetivos da presente pesquisa, que exigiu a necessidade de apresentação da proposta em linguagem adequada à faixa etária e desenvolvimento das crianças.

A fase exploratória, iniciada em Março de 99, foi importante não só para o planejamento das ações mas, principalmente, para preparar o caminho de implantação do programa, através de uma aproximação e busca de conhecimento de ambas as partes, educador e educandos, fortalecendo os contatos e no estabelecimento de aceitação e confiança no educador por parte do grupo de educandos.

\subsection{O Levantamento de Dados}

Para o levantamento das informações necessárias à pesquisa, várias estratégias metodológicas foram utilizadas, a partir da definição dos parâmetros através dos quais se objetivava observar, obtendo-se assim os dados para responder às questões formuladas inicialmente, quando da delimitação do problema.

Foram estes os parâmetros:

a) caracterização do espaço físico e funcional do clube e perfil de seus participantes;

b) caracterização e avaliação das atividades sua condução e produtos resultantes;

c) análise dos depoimentos dos sujeitos participantes diretos, representados pelas crianças

e dos sujeitos indiretos representados pela diretora e monitora do $\mathrm{CJ}$, e professores do ensino formal das crianças.

As estratégias metodológicas envolvendo técnicas e fontes diferentes foram representadas por: observação pessoal; entrevistas com as crianças, diretora e monitora; questionários aplicados nos professores do ensino formal; imagens fotográficas e registros das crianças. Elas permitiram compor e analisar a realidade estudada e serão melhor descritas a seguir. 


\subsubsection{A Observação}

A observação foi sem dúvida um procedimento básico na coleta de dados. Ela esteve presente em todos os momentos, durante e pós levantamentos de campo. Esse instrumento forneceu principalmente a descrição e identificação das características do clube, envolvendo as ações educativas e respostas de seus participantes. Em relação a estes últimos, ela nos permitiu verificar as apropriações de conhecimentos, habilidades e atitudes apresentadas frente ao trabalho, revelando a realidade.

LÜDKE e ANDRÉ (1986) chamam atenção para a influência do observador segundo sua história pessoal e bagagem cultural, mostrando a necessidade de um planejamento e domínio de técnicas de observação, definindo $O$ quê? e Como se vai observar?

PATTON (1980), citado por LÜDKE e ANDRE (1986, p.26), afirma que é preciso que o observador saiba fazer registros descritivos, separando detalhes relevantes e organizando as anotações através de um método rigoroso, de modo a validar seus dados

Uma variação do método de observação refere à observação participante. Esta, presente no estudo pela inserção da pesquisadora como condutora dos trabalhos no clube, é caracterizada por GIL (1994) como a participação real do observador na vida da comunidade, do grupo ou de uma situação determinada. Neste caso, o observador assume, pelo menos até certo ponto, o papel de membro do grupo. Dai porque se pode definir a observação participante como uma técnica pela qual se chega ao conhecimento da vida de um grupo a partir do interior dele mesmo. O referido autor oferece outra denominação a esta forma, observação ativa 
Embora não houvesse uma proposta de observação fechada, com roteiros previamente fixados que deveriam ser preenchidos ao longo do trabalho, alguns aspectos foram definidos a priori, como forma de direcionar a observação, para conhecer a perspectiva pedagógica e de relação entre os sujeitos envolvidos. Estes foram: o elenco de conteúdos; a forma de atuação do educador; as respostas dos educandos; e as relações estabelecidas entre os participantes, mediados pelo espaço e tempo, constituindo-se em um conjunto de informações que, agregadas às outras, compuseram os dados de campo

A organização dos conteúdos e materiais pedagógicos foram sempre preparados com antecedência, a partir dos encaminhamentos ocorridos em cada uma das sessões, segundo o interesse dos educandos e a proposta educativa. Esse planejamento permitiu selecionar os conceitos, preparar as atividades e seus respectivos materiais didáticos. Os dados referentes à aplicação foram registrados minuciosamente, durante as sessões, por uma auxiliar e completados pela pesquisadora, no mesmo dia, estruturando-se assim pequenos relatórios semanais.

Esses relatórios consistiram, por um lado, em descrições das ações desenvolvidas pelo educador, suas idéias e sugestões para novos encaminhamentos. E, por outro, nas respostas apresentadas pelos educandos, amostras de seus registros e produtos finais. Todo o processo foi registrado com fotos, que ilustraram as principais passagens. Os materiais, acumulados ao longo do período de levantamento de dados, serviram de substrato para a elaboração dos resultados, compondo este estudo.

\subsubsection{As Entrevistas}

Compondo o conjunto de anotações de campo, as entrevistas representaram outro instrumento importante na coleta de dados. Elas permitiram captar dos envolvidos diretos 
e indiretos, respectivamente crianças, diretora e monitora, informações e representações para que se pudesse caracterizar e descrever a realidade estudada.

A realidade apreendida através dos discursos dos individuos do grupo foi recolhida por meio de entrevistas estruturadas e semi-estruturadas, usando-se gravações magnéticas e transcrição literal das fitas.

É essencial salientar os cuidados requeridos nas entrevistas como respeito ao universo cultural e de valores dos entrevistados, evitando distorções e utilizando vocabulário adequado ao apresentar as questões. Tais aspectos foram importantes, especialmente com as crianças, porque estas eram originárias, na sua maioria, de outros estados do país, especialmente nordeste, e apresentavam dificuldades com o vocabulário e a fraseologia.

Para entrevistar as crianças, testou-se uma forma mais aberta, semi-estruturada. Era apresentada uma questão geral e pouco direcionada, permitindo que os depoentes falassem livremente sobre o tema. Essa forma gerou dificuldades no encontro das respostas por parte das crianças. Elas permaneciam em silêncio e/ou se mostravam em dúvida sobre o que falar, de modo que, freqüentemente, a entrevistadora precisava refazer as questões, direcionando-as e, de alguma forma, auxiliando na busca das respostas. Isto levou-a a optar pela entrevista estruturada, com questões pré-definidas. Essas enfocavam o aprendizado de Ciências e Saúde e sua importância, a eventual comunicação dos conhecimentos aprendidos com outras pessoas, fora do âmbito do Clube, e o interesse pelos temas expostos.

As entrevistas com as crianças foram aplicadas durante o processo do desenvolvimento das oficinas, nos últimos três meses do periodo de levantamento de dados. Em geral ocorriam ao final dos trabalhos do dia. Para tanto, organizaram-se grupos de 3 ou 4 crianças de cada vez, tendo sido ouvidos todos os participantes do 
Clube. Os grupos tiveram composição mista e procurou-se manter juntas as crianças que, de alguma forma, eram mais próximas e relacionadas. Essa forma de inquirir permitia que a entrevista ocorresse em ambiente com menor pressão, possibilitando que a resposta de um provocasse a resposta de outro, resultando em um efeito sinérgico.

A proposta em gravar os depoimentos, transcrevendo-os e analisando-os, permitiu registrar as colocações diretamente, sendo completadas com outras anotações, em especial expressões e gestos, que enfatizavam a linguagem verbal. Procurou-se desenvolver a capacidade de ouvir, estimulando quando necessário o fluxo natural de informações, sem forçar ou direcionar as respostas, como sugerem LÜDKE e ANDRÉ (1986). As transcrições das fitas foram feitas sempre no mesmo dia, de modo a não se perderem informações especialmente de entonação e gestual.

Sabemos que o recurso de gravação gera inibição, deixando os entrevistados pouco a vontade. Para minimizar este efeito, o instrumento foi utilizado em outros momentos, permitindo que as crianças se familiarizassem com ele.

Embora as entrevistas fossem grupais, elas forneceram dados discursivos e subjetivos que foram organizados, dentro da abordagem qualitativa, sob a ótica das Representações Sociais (RS), estruturando-se o Discurso do Sujeito Coletivo (DSC). Para tanto, os dados obtidos foram organizados, essencialmente, sob a forma de duas figuras metodológicas: Idéia Central e Expressões-Chave. Estas foram conseguidas a partir de trechos das respostas emitidas pelas crianças, as quais permitiram a identificação de palavras e expressões. Os diversos trechos foram posteriormente agrupados e categorizados segundo similiaridades ou equivalências, ou seja, pelo fato de conterem a mesma idéia.

Em relação às entrevistas feitas com as diretora e monitora do $\mathrm{CJ}$, no final do período de levantamentos de dados, estas forneceram-nos um conjunto de informações, 
em especial aquelas referentes à organização e proposta da instituição, bem como sobre a população atendida. Elas nos permitiram verificar como o Clube estava sendo visto e sentido, não só por elas, mas também pelas crianças e comunidade, uma vez que estão presentes diariamente no $\mathrm{CJ}$, mantendo contatos permanentes e constantes com as crianças e seus familiares. Para tanto, foram obtidos depoimentos gravados das respestas às questões abertas efetuadas durante o encontro.

\subsubsection{Visita à Escola}

Com o intuito de obter outras informações e estabelecer a triangulação dos dados, buscou-se contatar a instituição escolar onde estudava a maioria das crianças, E. E. João Cruz Costa. Esse contato tinha como proposta verificar como as ações do clube chegavam à escola, uma vez que nas entrevistas com as crianças havia indícios sobre comentários feitos por elas, com a professora e colegas de classe. Efetuado 9 meses após o início do programa, ele poderia nos fornecer, ainda, informações sobre o desempenho dos alunos no ensino formal.

A Escola Estadual João Cruz Costa está localizada à rua José Maria da Silva, s/ número, no próprio bairro Vila Nova Jaguaré, estando situada em uma das vias de acesso à favela. Contatos estabelecidos, com a coordenadora Prof. Maria Soares G. Garcia, levaram-nos até os professores. O encontro ocorreu em uma das reuniões de HTPC (Hora de Trabalho Pedagógico Coletivo), quando pôde ser feita a apresentação da proposta e deu-se a entrega do questionário previamente construído. O questionário, composto de 4 (quatro) questões, abordava sobre as características de desempenho escolar dos alunos envolvidos no programa do clube, enfocando as habilidades e o desempenho na área de Ciências e Saúde e as possiveis relações estabelecidas com os colegas, através de conversas e narrações. (Anexo 4) 


\section{A Análise dos Dados}

Ao definir os parâmetros a serem observados e já mencionados, como: o espaço físico e funcional do clube e seu potencial educativo, presentes através dos conteúdos, atuações e relações estabelecidas entre os participantes, educador e educandos, aquties resultaram em dados, representando o corpo de conceitos estudados, os procedimentos empregados e as respostas apresentadas por parte das crianças, revelando entre os vários aspectos, sua bagagem, identidade cultural, interesses, expectativas e avaliações

Tais dados permitiram interpretar, entender e avaliar a ação do clube nas dimensões educativa e pedagógica. Foram agrupados e discutidos a partir da construção de uma síntese descritiva cuja estrutura envolveu:

a) as ações encadeadas;

b) a apresentação dos diálogos mais relevantes;

c) os conhecimentos produzidos e construidos a partir das vivências e experimentações; e

d) os depoimentos.

Como parte integrante dos diversos trabalhos, uma amostra representativa dos registros preparados pelas crianças foi selecionada no conjunto de textos, desenhos, esquemas e tabelas. Esta e os registros fotográficos estão apresentados no capítulo referente aos resultados e discussão e expõem as ações empreendidas, dando uma dimensão legítima do trabalho efetuado e do desempenho dos educandos.

\section{A Teorização Novamente}

A luz das teorias referenciais, a etapa de análise e interpretação dos dados coletados completa-se com a construção de uma nova teoria, que permite explicar e compreender o fato ou processo enfocado. Desta forma, o pesquisador ultrapassa os 
limites de seus dados, estabelecendo novas relações, como afirma MINAYO (2000) buscando uma ordem, uma sistemática e uma organização do pensamento.

GOMES (2000, p.69), apoiando-se em MINAYO (1992), aponta três finalidades básicas desta fase no estudo: estabelecer uma compreensão dos dados; confirmar ou nào os pressupostos da pesquisa, respondendo às questões formuladas e ampliar o conhecimento sobre o objeto de estudo, articulando-o ao contexto científico e cultural. Assim, a teorização de todo o trabalho foi feita a posteriori e será tratada no capítulo referente à discussão. 


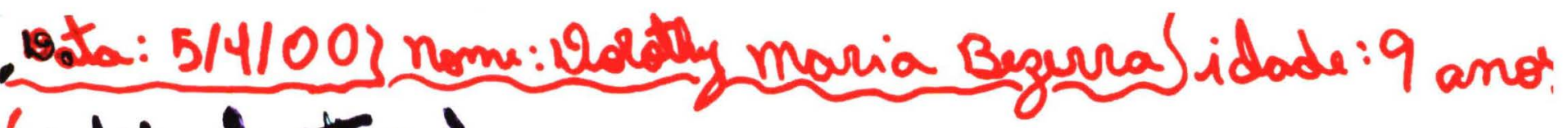
codeia aliustar da Jamimna.

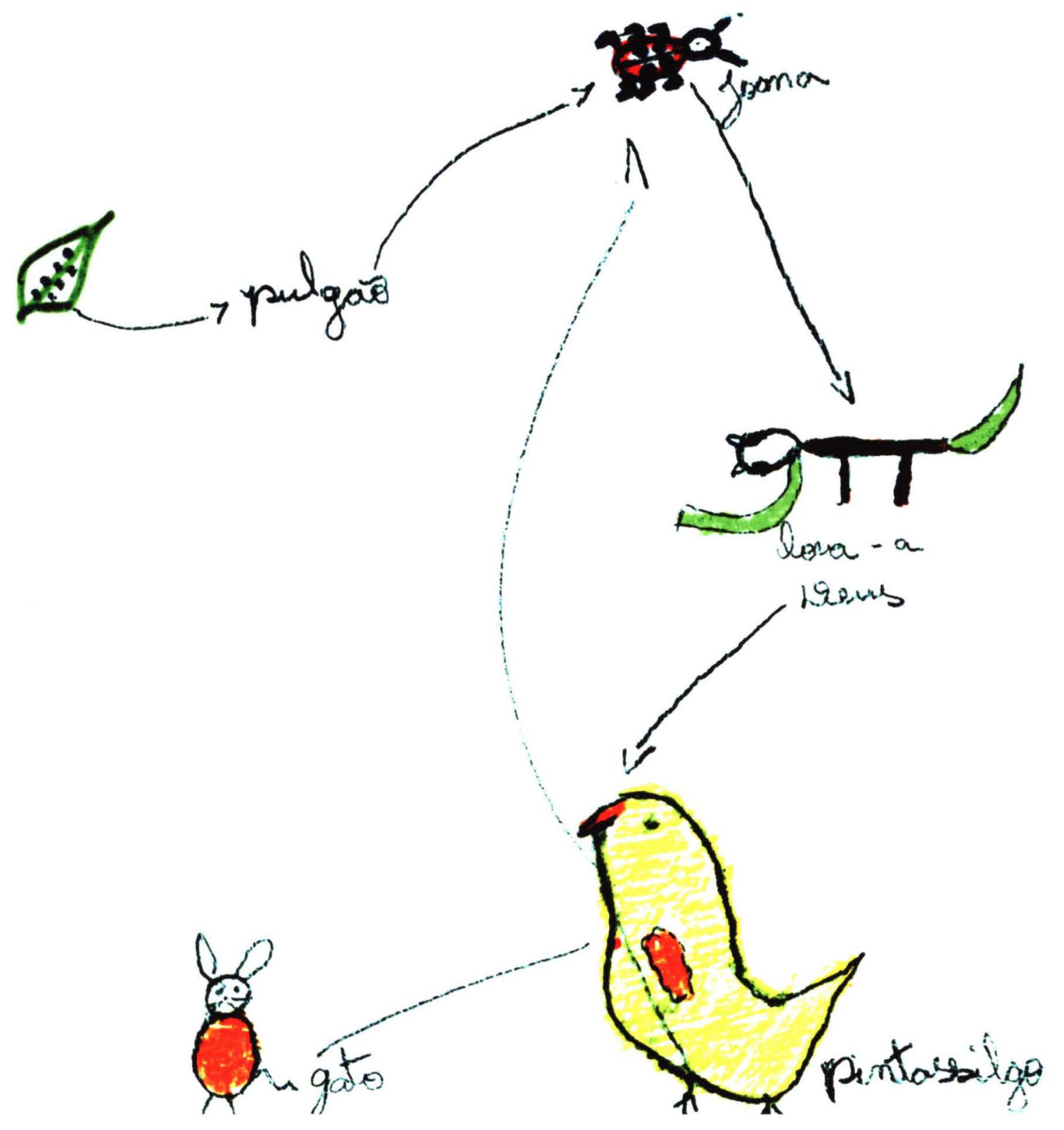




\section{III - RESULTADOS E DISCUSSÃO}

Apresentamos os resultados empíricos, obtidos pela ação educativa, originados de um programa construído especialmente para a criação e desenvolvimento de um Clube de Ciências e Cultura implantado em um Centro da Juventude $(\mathrm{CJ})$. A proposição dessa pesquisa esteve assentada, conforme apresentação em capitulos anteriores, na estruturação e desenvolvimento de um modelo educativo, na dimensão não-formal, possível de ser aplicado para crianças e jovens, visando para a educação e promoção em saúde.

As relações dinâmicas de interesse bidirecional, estabelecidas entre a pesquisadora e a instituição que acolheu a proposta, permitiram a implantação e construção do programa na íntegra. É preciso ressaltar que a instituição contribuiu não só com apoio referente ao espaço físico e de pessoal, mas também em relação à aquisição de parte dos materiais didáticos básicos, necessários para o desenvolvimento da proposta, tendo sugerido também o eixo temático e disparador, cujo título foi Alimentos e Nutrição.

Ao se constituir o grupo de crianças que participaria do programa, teve início a fase de planejamento para estruturar e organizar a ação. Nessa fase, reconhecida como exploratória, foram iniciadas as primeiras atividades visando efetivar a participação e engajamento dos educandos, tendo como principal propósito aproximar o educador das crianças, estabelecendo contato e formando vínculos de trabalho.

Para caracterizar o espaço vivenciado nas circunstâncias do $\mathrm{CJ}$, aqui apresentado como o clube vivido, e buscar as respostas e interpretações para as questões iniciais e norteadoras da pesquisa: O que é o clube? Qual o seu significado educativo? e Como ocorre sua ação educadora?, é preciso, inicialmente, a partir do conjunto de referências da educadora e da teoria presente na bibliografia, explicitar o que se identificou como o 
clube imaginado. A partir dele seria mais fácil interpretar as ações pertinentes ao clube vivido.

\section{O Clube Imaginado}

Tendo participado anteriormente em projetos de ensino de ciências, onde eram organizadas e planejadas ações voltadas para a cultura científica vinculadas a clubes, a pesquisadora pôde vivenciar o desempenho dessas organizações junto a escolas e outras instituições, como centros comunitários e prefeituras. Os resultados obtidos a partir dessas experiências apontavam para um trabalho com alto potencial educativo, com reflexos no trabalho escolar formal, atuando ainda de modo positivo na construção socializada do conhecimento e no desenvolvimento de habilidades e atitudes dos educandos.

Ao atuar e acompanhar os clubes implantados em diferentes instituições, pôde-se perceber também que essas organizações apresentavam grande flexibilidade e adaptabilidade, segundo contextos, realidades e história dos envolvidos, acabando por assumir formas peculiares. Os clubes vinculados às escolas, além de dar suporte ao trabalho escolar formal, fornecem subsídios na forma de estudos e projetos para outras atividades escolares como Feiras de Ciências, Semanas Culturais, Estudos do Meio e de Educação Ambiental.

Mesmo assumindo feições tão próprias, os clubes apresentam estrutura funcional comum, que thes confere similaridade em suas características. Estes, muitas vezes, subvencionados pela instituição que os abriga, são conduzidos por professores e/ou educadores envolvidos em objetivos educativos comuns. 
O clube, portanto, é um espaço físico e funcional, estruturado administrativamente. Está voltado para a educação não-formal e congrega educandos e educadores de modo organizado, sistemático e permanente, comprometidos em ampliar o conhecimento. Deste modo, através de projetos voltados para a informação e formação dos participantes, são desenvolvidas as habilidades necessárias para diferentes competências. Sob orientação, crianças e adolescentes organizam e preparam estudos sobre temas variados, multi e interdisciplinares nas diferentes áreas do conhecimento científico, tecnológico, social, ambiental e cultural, de interesse pessoal, do grupo e/ou da comunidade.

Os projetos são desenvolvidos através de atividades interligadas dentro de um tema voltado para participantes com diferentes idades e bagagens de conhecimento, congregados voluntariamente através de divulgação, visando estabelecer compromissos participativos dentro do projeto ou subprojetos, tendo em vista produzir estudos de caráter científico e cultural.

No clube, crianças e jovens dividem um espaço democrático, participando da escolha dos temas, seu encaminhamento, execução e avaliação, intercambiando idéias, partilhando e construindo socialmente o conhecimento.

Dessa forma, através de seus objetivos e estratégias, o clube trabalha não só a informação, mas permite desenvolver e completar a formação de seus participantes, no aspecto educacional, social e pessoal, trabalhando habilidades de pensamento, destreza e comunicação, além das capacidades e atitudes.

Seus objetivos gerais podem ser assim definidos:

\section{a) pedagógicos}

1. estimular o desenvolvimento de diferentes capacidades de pensamento, de comunicação, destrezas e atitudes, atuando na informação e na formação; 
2. desenvolver a criatividade através da formulação de explicações para fatos e fenômenos, permitindo explicitar “os modos de ver”, testar hipóteses e diferentes formas de expressar as idéias;

3. encorajar a busca e o manuseio de dados em diferentes fontes de informação: experimental, bibliográfica e no campo; e

4. integrar os conteúdos conceituais desenvolvidos com a bagagem e a experiência cotidiana.

b) sociais

1. desenvolver atividades que contribuam para a formação científica e cultural, colocando o educando no contexto social e capacitando-o para novas leituras de mundo;

2. possibilitar a socialização e integração com o ambiente, através de trabalhos em diferentes áreas do conhecimento;

3. estabelecer intercâmbio das informações geradas no grupo com a comunidade.

Assim, além dos objetivos pedagógicos, o clube apresenta ainda objetivos sociais e de interesse pessoal, que acabam por dinamizar os trabalhos, lembrando, como aponta DIAS (1995), que alguns clubes permitem a oportunidade de encontro de profissões.

Dois aspectos sociais importantes são atendidos pela ação do clube. Um refere-se à ocupação do tempo livre, enquanto que outro se refere ao processo de socialização. REIS (1973) chama a atenção para o fato da proposta oferecer, entre outros objetivos, oportunidades para que as crianças trabalhem em grupo, em situações de estímulo e 
indagação, cultivando uma qualidade importante apresentada pelas crianças, a curiosidade em relação aos fatos e fenômenos que as cercam.

Segundo documento preparado pela UNESCO para a Oficina Regional de Educação para a América Latina e Caribe, o conceito de clube aparece como uma associação permanente de crianças e jovens com uma organização estabelecida, que, sob orientação de assessores qualificados, desenvolve atividades que contribuem para educação cientifica e tecnológica de seus membros e da comunidade. A publicação, apresentada sob a forma de um manual, está voltada para professores e alunos e coloca essa modalidade educativa como um nivel de atividade fundamental e permanente, através do qual emanam outras modalidades de iniciação científica para jovens (SECAB/UNESCO, 1985).

O manual citado apresenta além dos objetivos as formas de organização e avaliação, sugerindo diferentes atividades educativas que poderão ser desenvolvidas dentro de um clube, tais como:

- Realizar projetos e estudos cientificos e tecnológicos, permitindo o envolvimento pessoal dos educandos na busca de soluções para problemas científicos;

- Obter informação sobre os problemas e realizações cientificas, tecnológicas e industriais da comunidade, criando relações e intercâmbios com a comunidade;

- programar cursos, palestras, projeção de filmes e diapositivos, excursões e visitas de caráter científico, em especial os cursos e palestras que permitem estabelecer relações e obter apoio de universidades ou outras instituições locais;

- Organizar elou participar em outras atividades cientificas, como Feiras de Ciência, onde seus participantes podem apresentar seus trabalhos a outros jovens e pessoas da comunidade;

- Estudar vida e obras de cientistas notáveis, resgatando aspectos importantes da História da Ciência; 
- Publicar revista ou jornal, os quais, mesmo que modestos, abrem a possibilidade de intercâmbio com outras instituições;

- Colaborar com a instituição escolar, preparando material didático para apoiar a criação e manutenção de museus, viveiros e laboratórios;

- Organizar visitas ao clube, como forma de contribuir para sua difusão e informaçãc permitindo conhecer suas atividades.

É preciso salientar que o conhecimento conseguido anteriormente sobre as interações, rotina e relações educativas que caracterizavam o clube imaginado apontavam para um não determinismo, mas se expressavam em um dinamismo de trocas entre os educandos entre si e entre eles e o educador, com reflexos em relação aos conhecimentos, valores e significações presentes na bagagem dos alunos, estruturados formal e não- formalmente, e originários de outras instâncias educativas como a família e a escola.

\section{O Clube Vivido}

$O$ conjunto de referências, estruturado a partir das vivências e experiências anteriores, presentes no clube imaginado, serviu como substrato para a implantação e desenvolvimento do novo clube, no $\mathrm{CJ}$ do Jaguaré. $\mathrm{O}$ grupo constituído apresentou uma série de atributos, como resultado da articulação entre as ações pedagógicas propiciadas pelo educador e aquelas surgidas como resposta por parte dos educandos. Assim, estão apresentadas a seguir as características do clube vivido segundo as dimensões já apontadas na metodologia. 

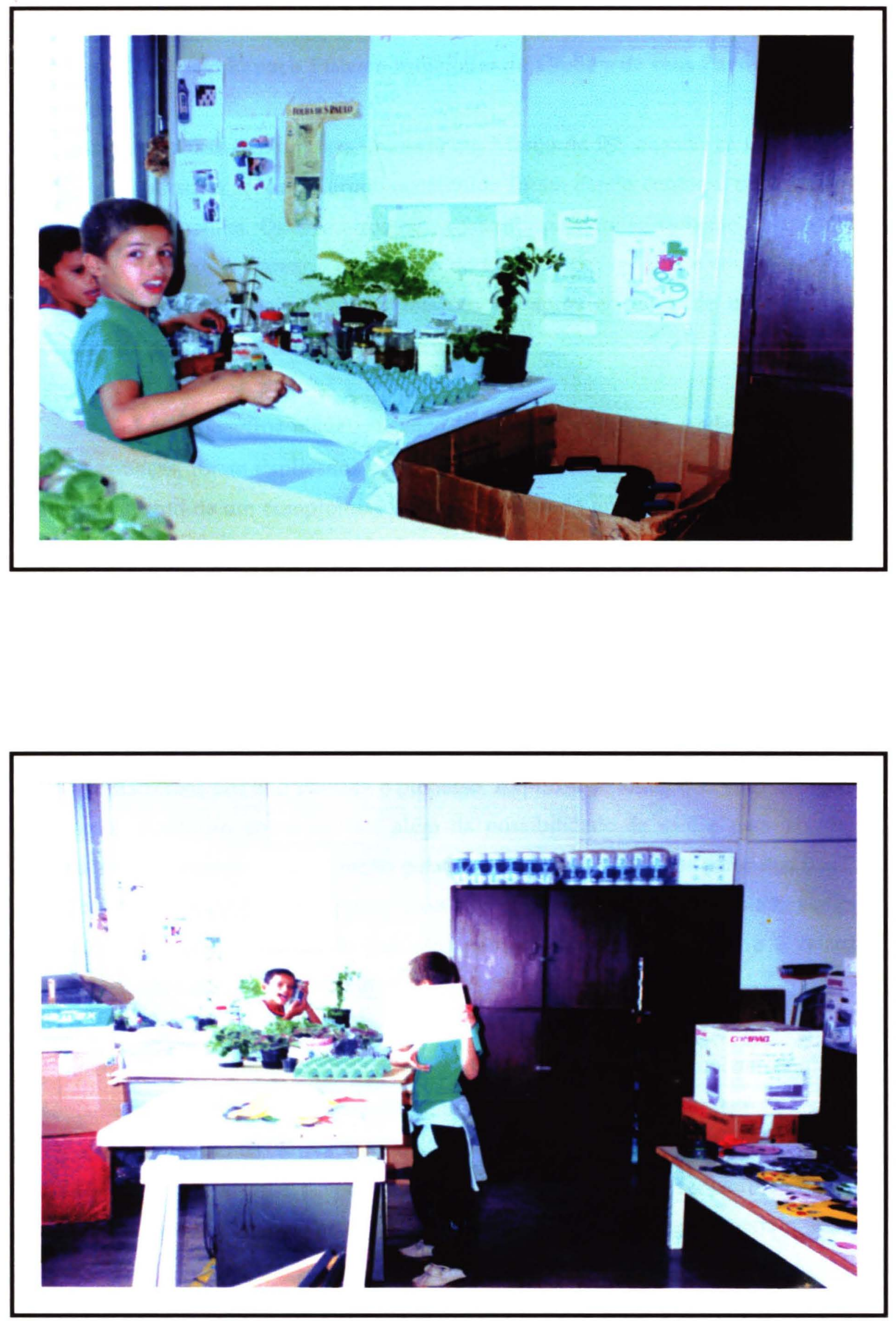


\subsection{Caracterização do Espaço Físico e Funcional do Clube e de seus Participantes}

A partir da fase exploratória, iniciada em Março de 99, quando se firmaram os primeiros encontros, as ações do grupo constituído foram dando contomo ao trabalho e ao espaço do novo clube. Os encontros nessa fase foram estrategicamente desenhados, não só para introduzir e clarear a concepção do trabalho pedagógico e educativo, mas, sobretudo para o estabelecimento das relações de aproximação e de conhecimento interpessoal da educadora e das crianças envolvidas.

Assim, nos encontros iniciais, usando linguagem apropriada e adequada à faixa etária das crianças, foram explicados os objetivos da proposta educativa e a importância do estabelecimento de um compromisso de participação do grupo. Visava-se o ensino e a aprendizagem de conhecimentos voltados para as Ciências e a Saúde relativos ao tema Alimentos e Nutrição. Foi interessante observar que as crianças, já no primeiro encontro, questionaram a minha presença perguntando: O que ela estava fazendo aqui?

Nos encontros foram explicitados os objetivos deste trabalho de pesquisa, cujo propósito envolvia estudos e a necessidade da permissão das crianças para usar os dados e registros realizados por elas durante o processo. Explicou-se ainda que, para compor o estudo seria necessário entrevistá-las, além da possibilidade de saídas para visitas e trabalhos fora do espaço do CJ - razão pela qual era importante, por parte dos pais, a assinatura do Termo de Consentimento. Essa forma de conduzir, franca e clara, sempre permeou as atividades, permitindo que elas percebessem que o espaço e a relação estabelecidos eram abertos e confiáveis.

Ficou evidente que as explicações sobre o trabalho educativo proposto no clube e apresentadas nos encontros iniciais foram pouco percebidas pelas crianças, pois elas não tinham a real dimensão da forma e condução do trabalho. Na verdade, a idéia do clube foi sendo construida com o próprio fazer. Esses dados poderão ser verificados nos depoimentos registrados, que estão apresentados e discutidos neste capítulo. Hoje, 
quinze meses após o início do programa, as crianças que ainda permanecem no grupo conseguem explicar aos novos participantes, que chegam a cada início de semestre o que é o Clube de Ciências e o que se faz nele.

No transcorrer do mês seguinte (Abril de 99), o fazer das crianças era ainda tímido. Envolvidas nas ações educativas disparadoras e promotoras, o clube foi se estruturando e havendo a implementação gradativa do programa. Elas eram estimuladas a participar contando "coisas", ouvindo os colegas, exprimindo a curiosidade, levantando questões, buscando respostas, estruturando pequenos experimentos e estudos. Essa forma permitia trocas entre elas e a educadora, estabelecendo vínculos de interesse e confiança, aproximando-se e mostrando-se envolvidas com o trabalho, cumprindo as "coisas combinadas".

Não houve a preocupação em preparar primeiro o espaço físico para então iniciar as atividades. Essas foram ocorrendo simultaneamente com a construção do espaço, estando este intimamente relacionado às ações empreendidas. A necessidade de um lugar para guardar e armazenar os materiais angariados, os instrumentos, os experimentos preparados, os registros e textos coletivos, geraram e desencadearam nas crianças a necessidade de organização do espaço.

Ficou combinado que elas, ajudadas pela monitora, construiriam com tijolos, cavaletes e um tampo de porta disponível a mesa para o clube. Assim, ainda no mês de Abril, o espaço já estava bastante organizado, com uma mesa recoberta com papel e toalha plástica e um cartaz anunciando: Clube de Ciências (Anexo 6, Figs 1 e 2).

Nos meses seguintes, a mesa e as paredes ao redor foram ganhando aos poucos amostras de solo, coleções de sementes, sementeiras, frascos com plantas, exemplares de folhas, caules e raizes, pequenos viveiros com lagartas, painéis, fotos e artigos de jornais, desenhos, textos coletivos, listas de nomes de plantas da horta, tabelas com medidas de crescimento das plantas e tiras de cartolinas com palavras-chaves. Todos 
esses materiais foram produtos resultantes do próprio trabalho das crianças, angariados ao longo das múltiplas ações emanadas do clube.

O espaço foi se tornando vivo e dinâmico, estruturando-se como resposta à ação educativa planejada, segundo uma estratégia participativa proposta no projeto, organizando e, principalmente, consolidando o trabalho do clube (Anexo 6, Fig. 3).

Ao atuar dessa forma, as crianças estavam imersas em um ambiente não só científico mas, sobretudo, cientifizador, estimuladas a pensar e atuar de maneira diferenciada e que as aproximava da Ciência. A educadora, responsável pelo planejamento e orientação das decisões pedagógicas, estava incumbida de propiciar este meio

$\mathrm{O}$ ambiente educativo era resultante das ações e comprometimentos bilaterais e conjuntos, tendo de um lado as crianças mobilizadas para atuar e desempenhar as ações educativas propostas e combinadas, e do outro a educadora mobilizada na articulação, a partir de demandas educativas selecionadas, considerando a proposta pedagógica e os interesses e o referencial das crianças. Tal mobilização resultava, por parte da educadora, em uma busca constante para a seleção e organização das concepções e conceitos a serem incorporados, definição das ações e estratégias didáticas, seleção e preparação dos materiais didáticos necessários.

Criar um ambiente cientifizador é promover situações educativas mobilizadoras e motivadoras que permitem que as crianças se transformem, ampliando sua compreensão, encontrando significado para o conhecimento, expressando seus interesses e questionamentos e testando suas idéias sobre os fatos e objetos, que fazem parte de sua realidade e de seu mundo. Infelizmente, essa forma de atuação está muito além de como as crianças exercem as atividades de Ciências na escola. FRACALANZA et al. (1986) apresentam de forma sintetica e clara como é essa atuação na escola. As crianças devem permanecer o tempo todo caladas, ouvindo o professor. A informaçào científica é 
fornecida e deve ser memorizada, sendo a palavra a única interação permitida. Podemos acrescentar que muitas vezes há atividades, mas essas se fecham em si próprias, se enquadrando dentro do que WEISSMANN (1998) chama de ativismo. A atividade pela atividade. FRACALANZA et al. (op.cit.) sugerem formas que pressupõem a participação ativa em sala de aula, permitindo que os alunos possam verificar as transformações de objetos, materiais e seres vivos, apontando a atenção necessária para outras fontes de conhecimento científico como os livros e as entrevistas com especialistas. Eles salientam a importância da incorporação do conhecimento com o desenvolvimento de operações de pensamento.

Atuar dentro de uma visão cientifizadora, criando vínculos entre o conhecimento e a realidade natural e social é, na verdade, não só buscar a interação, mas, sobretudo, uma qualidade de interação. Ao discutir sobre o valor social do conhecimento científico, FUMAGALLI (1998) aponta que a interação entre o conhecimento do senso comum e a realidade até ocorre de forma eficiente pelas crianças e jovens, porém com baixa qualidade. Citando FOUREZ (1987), a referida autora afirma que o conhecimento pode possibilitar uma participação ativa e com senso crítico na atual sociedade, na qual o fato cientifico está na base de grande parte das opções (FUMAGALLI,1998, p.17). Ela enfatiza o valor do conhecimento científico na prática social das crianças, não só para a formação dos "futuros cidadãos", mas porque elas são parte integrante de um corpo social atual. Esses argumentos são suficientemente fortes para dar suporte e enfatizar o ensino de conceitos científicos para as crianças.

Desde o primeiro momento buscou-se estruturar uma rotina dentro do trabalho. Ela não tinha como proposta obter uma forma rigida e não flexível, mas caracterizar uma situação, um momento diferenciado, que pertencia a todos participantes. A rotina também estabelecia o comprometimento para o trabalho que viria. Foi explicitada já no primeiro dia de encontro e continuou sendo aprimorada, acabando por se incorporar no fazer das crianças. Tal rotina, em geral, seguia uma estruturação representada segundo três momentos distintos, interelacionados e em sequência, caracterizando o fazer no 
clube. Eles foram designados como: conversa na roda, desenvolvimento das tarefas e fechamento. Esses momentos serão melhor explicados a seguir, dando uma visão do conjunto das ações empreendidas em cada dia de encontro no clube

\section{Conversa na roda}

A conversa na roda marcava o início das atividades do dia. Sentados em círculo, em cadeiras ou no chão, as crianças e a educadora podiam se ver e ouvir umas às outras. A roda caracterizava uma situação organizada, de maior proximidade e comprometimento com a participação. Neste momento resgatavam-se, com os relatos orais dos participantes, crianças e educadora, as atividades feitas anteriormente, os conteúdos vistos e as noções desenvolvidas. Nela ocorriam ainda a apresentação do tema e dos assuntos do dia, a apresentação de informações, conhecimentos e explicações pelas crianças, o estabelecimento de “discussões", a introdução de novos conceitos, a organização do trabalho a ser feito, grupal e individual, a apresentação de materiais e objetos, a leitura de textos especializados e de livros de história e a construção de textos coletivos. Combinavam-se também as próximas etapas do dia ou da proxima semana, a observação dos resultados referentes aos experimentos finalizados e aos em andamento (Anexo 6, Fig. 4).

A organização da roda era o marco inicial dos trabalhos e se manteve tão forte que tão logo as crianças me avistavam já se organizavam, esperando minha entrada no grupo. Neste momento, muitas vezes, havia disputa para que se sentasse ao lado de um ou de outro. O mesmo acontecia com a monitora que auxiliava nos registros e anotações e nos atendimentos às crianças, durante as diversas atividades. 


\section{Desenvolvimento das tarefas}

Este momento caracterizava-se pela ativa e intensa participação dos educandos na execução das mais variadas propostas didáticas. Com supervisão da educadora e da monitora, as crianças movimentavam-se organizando o espaço, reorganizando-se nos grupos ou no seu trabalho individual, de forma a desenvolver as tarefas pré-definidas na roda. Elas envolviam atividades como a preparação de painéis e cartazes, preenchimento de fichas e tabelas, observação de materiais ao microscópio, desenhos das observações feitas ao microscópio, montagem de experimentos e trabalhos na horta: plantio, desbaste, retirada de pragas, irrigação e colheita (Anexo 6, Fig. 5).

Outro aspecto marcante desse momento era a grande interação entre os educandos. Envolvidos com as tarefas em grupo, havia situações que geravam conflitos e discussões acirradas, em especial, quando da definição das etapas e funções na execução do trabalho. Mas, mesmo nessas circunstâncias, as crianças acabavam se organizando e ajudando umas às outras. Nas atividades em grupo, a divisão de trabalho permitia que cada uma delas desempenhasse sua função, segundo suas capacidades. Para os trabalhos individuais, a ajuda dos colegas fazia-se presente para aqueles que tinham dificuldades de entendimento e na leitura, na escrita, na elaboração de desenhos ou, com a coordenação motora, na hora de recortar e colar figuras.

\section{Fechamento}

Cada encontro semanal durava cerca de 2 (duas) horas. O momento referente ao fechamento era definido não só pelo tempo, mas também pela finalização dos trabalhos do dia. Nessa hora, algumas crianças, especialmente as menores, já se mostravam com dificuldade de concentração. As crianças apresentavam seus trabalhos umas às outras, explicando como haviam sido feitos e os produtos resultantes eram arrumados na mesa ou afixados nas paredes do clube. $\mathrm{O}$ momento era também usado para organizar e cuidar 
do espaço: aguando as plantas, limpando os viveiros, reorganizando os painéis, guardando os instrumentos usados na horta e removendo os cartazes antigos. Em uma caixa de papelão eram depositados os materiais das oficinas antigas que não estavam sendo mais usados.

O grupo, constituído por trinta e duas crianças, era heterogêneo em idade e em desenvolvimento. Todas estavam cursando as séries iniciais, $1^{\mathrm{a}}$ a $4^{\mathrm{a}}$ séries, do ensino fundamental. Isso, no entanto, não garantia a alfabetização, pois, mesmo estando nas séries finais do ciclo básico ( $3^{\mathrm{a}}$ e $4^{\mathrm{a}}$ séries), algumas tinham muitas dificuldades na leitura e escrita. No entanto, tal fato não foi pretexto para a não-realização das propostas, pois a convocação para participar requisitava por parte da criança o que melhor ela podia efetuar dentro de seus limites, cooperando e contribuindo na hora de executar as tarefas Dessa forma, quando havia necessidade de escrita, eram mobilizadas aquelas que melhor sabiam fazê-lo. Assim, ao preparar um painel, enquanto umas desenhavam, outras escreviam, outras recortavam e/ou colavam as figuras.

Durante a roda ou mesmo no desenvolver do trabalho, algumas crianças se envolviam em pequenas brigas, geradas principalmente por posse de objetos, execução de tarefas, definição de lugar na roda ou aguardando na fila para observar ao microscópio, mostrando uma atitude egocêntrica, esperada em geral para faixas de menores de idade, como aponta BEARD (1978) em seu estudo sobre Piaget. Nesses momentos, ao serem interpeladas, as crianças não conseguiam se explicar, não se colocando no lugar do outro e nem considerando sua maneira de ver como uma entre outras

FREIRE (1983) mostra, através dos textos de Piaget, que o estabelecimento repetido de relações interpessoais, permitindo a apresentação de opiniões, concordâncias e discordâncias, levam a criança a tomar conhecimento do outro. A estruturação da roda era a possibilidade de aumentar, entre outras coisas, o conhecimento das crianças entre si, bem como da educadora em relação a elas e também 

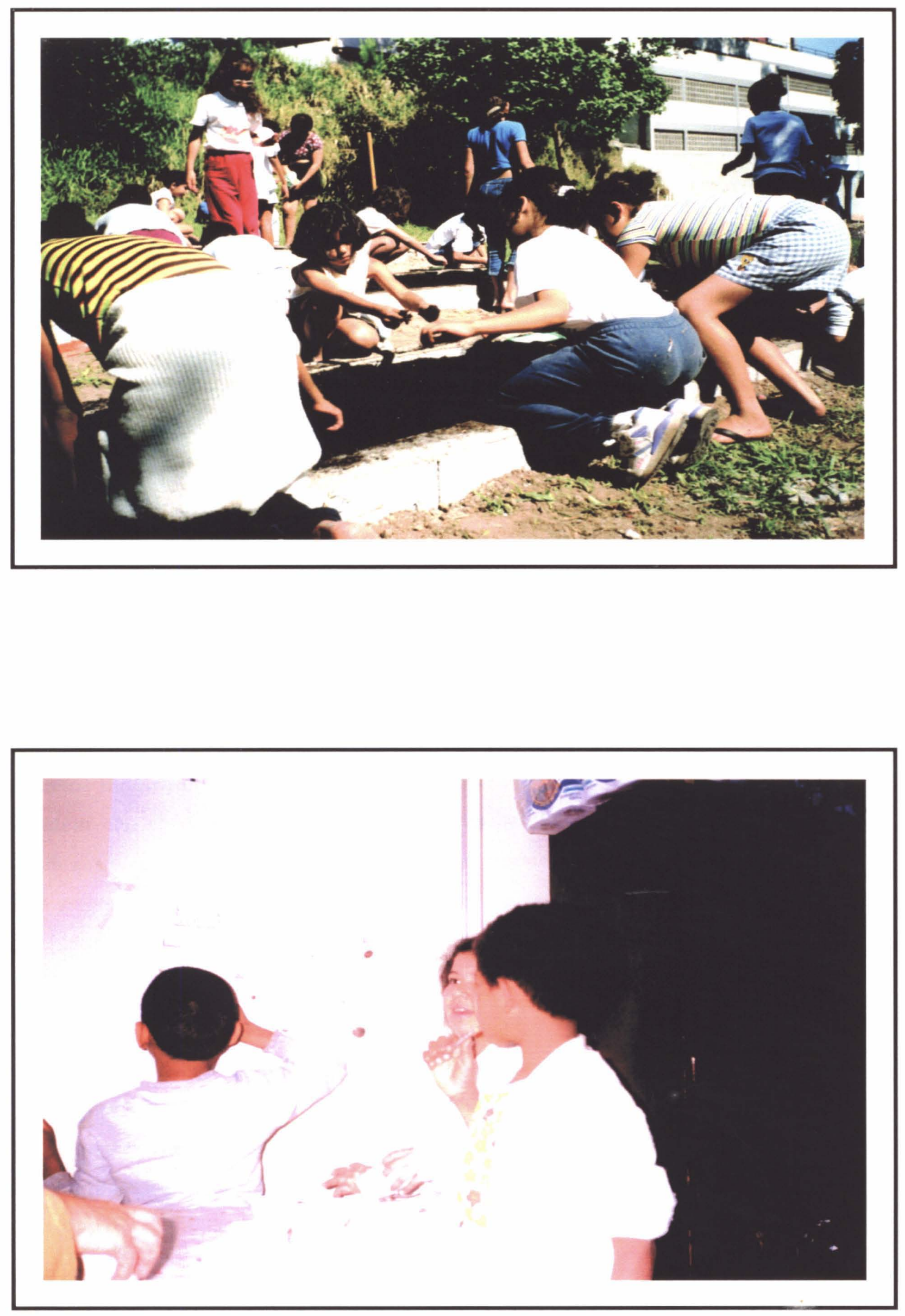
delas em relação à educadora. Nesse momento o papel exercido pela educadora era o de coordenar, encorajar e facilitar a discussão, estabelecendo questões, desafiando o grupo a crescer na compreensão dos modos de ver dos outros, mas também do conhecimento espontâneo presente na bagagem de cada um.

\subsection{Caracterização das Atividades, sua Condução e Produtos Resultantes}

Descrevemos aqui as ações educativas efetuadas, apresentando e caracterizando os conteúdos e as noções estudadas, bem como a forma como foram conduzidas as atividades. A partir dessas ações, apresentamos as respostas e os produtos resultantes do desempenho dos educandos. A produção das crianças, representada por registros escritos e desenhos, foi inserida no texto como forma de dar suporte à descrição dos dados. Estão presentes, ainda, fotos que registram os diversos encontros ocorridos no clube

Os dados apresentados e discutidos, conseguidos a partir do desenvolvimento de cerca de 60 sessões, estão agrupados de modo a obter-se uma síntese referente aos diversos momentos do trabalho, desenvolvido entre março de 99 e junho de 2000 . Eles refletem não só os conteúdos conceituais e as habilidades, mas a forma como foram conduzidos os trabalhos e a atuação e nivel das respostas das crianças, compreendendo a fase exploratória, quando foram introduzidos os assuntos referentes aos alimentos e nutrição, e a seguinte, incluindo o planejamento e execução da horta.

O tema permitiu o desenvolver das ações, com a apresentação de conteúdos conceituais nos seguintes subtemas:

- Alimentos de todo dia as refeições e suas características;

- A origem dos alimentos vegetal, animal e mineral:

- A utilização das plantas na alimentação: 
- As principais estruturas das plantas: raiz, caule, folhas, flores, botões, flores, frutos e sementes;

- A transformação dos alimentos: cozimento;

- As embalagens: datas de validade e de fabricação, composição e reciclagem;

- O estudo da semente e a germinação: etapas e fatores;

- Diferentes tipos de alimentos e sua função;

- A horta: medidas, instrumentos, solo, vegetais, cuidados e manutenção, colheita;

- Os animais da horta;

- A água: importância para as plantas, animais e homem;

- A água: ciclo e uso;

- O microscópio e seu uso.

Em relação às habilidades, tendo como referência os textos de RATHS et al. (1977) e BLOOM et al. (1983), foi estruturado um rol de atividades envolvendo ações segundo as categorias apresentadas a seguir:

- relativo a observar: identificar, denominar, distinguir, descrever;

- relativo a manipular: construir, armar, montar, selecionar materiais, colecionar;

- relativo a medir: ordenar, contar, igualar, estimar, ler escalas, comparar, calcular;

- relativo a classificar: agrupar, categorizar, organizar, relacionar, identificar, comparar;

- relativo a comunicar: registrar,ilustrar, escrever, colocar dados em tabelas, interpretar;

- relativo a avaliar: escolher, decidir, recusar, aceitar, discutir;

- relativo a inferir: deduzir, formular hipóteses, extrapolar, concluir;

- relativo a investigar: planejar, formular hipóteses, experimentar, controlar, verificar, descobrir.

É preciso salientar que buscou-se criar situações de aprendizado cujas atividades 
tinham como proposta convocar uma ou mais das capacidades relacionadas, envolvendo categorias de pensamento relativamente mais simples, como observar, e categorias mais complexas, como inferir e investigar. Os autores mencionados ( RATHS et al.,1977 e BLOOM et al.,1983) evidenciam que as oportunidades de experimentar tais pensamentos podem contribuir para a maturação do indivíduo.

Os conteúdos selecionados foram organizados e elencados com a implantação e desenvolvimento do clube, segundo a proposta e as demandas de conhecimento, essas geradas, muitas vezes, a partir do interesse e curiosidade das crianças.

As sessões do primeiro semestre trataram dos alimentos, ficando o estudo da horta para o segundo semestre de 99 e o primeiro de 2000. Essa determinação foi feita tendo em vista a busca de um espaço para a implantação da horta, as condições climáticas favoráveis para um bom desenvolvimento dos vegetais, no fím do inverno e início da primavera e a relação entre a educadora e crianças, possivelmente mais consolidada naquele momento do trabalho.

\subsubsection{A Cronologia do Trabalho: Março a Junho de 1999}

Ao iniciar o trabalho e discutir o espaço do Clube, as crianças foram sondadas sobre os conteúdos de Ciências e Saúde que já haviam estudado no ensino formal. Referindo a essa última, elas destacaram as doenças: a osteoporose, a dengue e o câncer, afirmando não lembrarem bem o que eram. Quanto aos assuntos de Ciências, não conseguiram, naquele momento, localizar as noções ou conceitos que haviam estudado ou que estavam estudando. Porém, com o desenvolver do trabalho, algumas noções foram pouco a pouco sendo lembradas ao se reportarem sobre as atividades da escola. 
Em seguida, foram apresentadas questões a respeito dos alimentos ingeridos por eles naquele dia, no café da manhã, e os que em geral comeriam em outras refeições. A partir dessa conversa, as crianças foram selecionando figuras sobre os diferentes tipos de alimentos, separando-os segundo seu consumo nas diferentes refeições. Essas figuras foram utilizadas na elaboração de três painéis entitulados: CAFÉ DA MANHÃ ALMOÇO - JANTAR.

A menção do ovo como um tipo de alimento que era usado sob várias formas, nos levou ao estudo mais detalhado de sua estrutura. Assim, as crianças examinaram a gema e a clara cruas, tocando-as com os dedos. Tendo amostras de diferentes ovos, de galinhas, de codorna e de um pássaro denominado "quero-quero" (Vanellus chilensis), elas compararam e descreveram o tamanho, a forma e a cor das cascas. A leitura do livro $\underline{\mathrm{O} \text { ovo }}{ }^{1}$ desencadeou uma discussão a respeito da sua função na reprodução das aves, e o papel da gema como fonte de alimento para o filhote.

Uma visita à cozinha do $\mathrm{CJ}$ permitiu que as crianças reconhecessem $\mathrm{e}$ identificassem os alimentos crus, introduzindo a idéia referente à origem animal, vegetal e mineral e a forma como alguns alimentos eram tratados e transformados para serem consumidos. Às perguntas Quem compra os alimentos em casa? e Onde se compram os alimentos? algumas crianças levantaram a mão, informando os preços dos ovos, carne, feijão, tomate, pão e outros gêneros alimentícios, e também onde eram comprados. Este questionamento resultou na chance de revisão dos nomes dos locais onde são comprados os diversos alimentos e as profissões dos diferentes vendedores. Discutiu-se também a respeito da quantidade comprada, diferenciando-os segundo as noções unidade/dúzia, volume/peso e custo

$\mathrm{O}$ conceito referente à origem dos alimentos gerou dúvidas e dificuldades. $\mathrm{O}$ próprio termo origem se mostrou dificil, pois as crianças não conheciam o seu

\footnotetext{
1 Jcuncsic, (i. e Bourgoing, P. O Ovo. São Paulo: Editora Melhoramentos: 1991
} 
significado. Ao ser explicada, a palavra acabou sendo usada por um dos meninos ao mencionar a procedência de sua família, vinda de um estado do nordeste. Isso permitiu que as outras usassem a palavra no mesmo contexto, entendendo seu sentido. Observando as diversas farinhas e o café, as crianças não conseguiram reconhecer sua origem vegetal. Para tanto, vários exemplos foram usados e como forma de concretizar a idéia montou-se um painel onde foram colocadas as etapas de transformação do café. $\mathrm{O}$ painel foi organizado com pó-de-café, café granulado, grãos torrados, grãos frescos e ramos das plantas com folhas e com frutos verdes e maduros. Durante a montagem as crianças experimentaram os frutos maduros, reconhecendo as sementes e o seu gosto característico. Daí surgiu a questão Quem sabe fazer café?, algumas crianças explicaram como elas e suas mães preparavam o café usando pó e água quente. Perguntei se daria certo usar água fria e elas ficaram em dúvida. Experimentos misturando pó de café com água fria e quente permitiram que as crianças verificassem como a temperatura ajudava na extração do sabor e aroma (Anexo 6, Fig. 6).

A transformação dos alimentos para o consumo foi um aspecto bastante enfatizado. Amostras de alimentos representados por sementes (feijão, milho), frutos (caqui, banana, limão), folhas (espinafre, alface, couve), raizes (mandioca, mandioquinha) e farinhas (milho, mandioca e trigo) foram apresentadas às crianças, que os agruparam em duas categorias, segundo a necessidade ou não de cozimento

A questão do uso das plantas como alimento envolveu várias sessões. Foram feitos reconhecimentos das partes dos vegetais: raiz, caule, folhas, flores, frutos e sementes. As crianças foram estimuladas a tocar, cheirar e sentir o gosto, tentando identificá-las através das diversas estruturas e dos ramos com folhas. Foram testados hortelã, manjericão, folhas de laranjeira, frutos do café, couve, espinafre, brócolos, cenoura, mandioquinha, batata doce, gengibre, cebola, alho, maracujá, vagem e uma dezena de outras plantas. Algumas crianças lembraram dos chás usados quando estavam com dor de barriga, com verme, com febre e inclusive nas benzeduras. Uma menina 
contou na roda, Meu vô usa essa planta pra fazê uma reza quando eu tô doente! Embora muitos nomes fossem conhecidos das crianças, por vezes elas não conseguiam identificá-las ao verem as plantas in natura.

Despertou interesse e surpresa colocar batata doce e cebola para brotar em frascos com água. $O$ crescimento foi acompanhado periodicamente, com as crianças aprendendo a fazer medidas do crescimento das folhas e raizes com uma régua e a montar uma tabela, anotando os dados e comparando o desenvolvimento das raizes que se formaram. As novas plantas obtidas acabaram plantadas no jardim do CJ. Essa iniciativa levou as crianças a experimentarem o brotamento de tubérculos e "raizes" como batata inglesa, cenoura e gengibre.

O estudo das estruturas vegetais permitiu que as crianças usassem seus atributos para agrupá-las. Dessa maneira, elas foram encorajadas a usar a cor, a forma, o cheiro, o tamanho da folha e o uso na alimentação como critérios para os conjuntos. Interessante foi a pergunta de uma menina, ao observar as vagens da árvore "pata-de-vaca" (Bauhinia sp), presente no pátio do CJ. Ela queria saber se essa planta era parente do feijão. De fato, ela estava correta, pois, embora as plantas sejam muito diferentes, ambas apresentavam um fruto do tipo legume, que é uma característica da família leguminosa, à qual ambas pertencem.

$\mathrm{O} \mathrm{CJ}$ oferece refeições todos os dias às crianças e, naturalmente, os alimentos são comprados em grandes quantidades. Ao visitar a despensa, elas ficaram surpresas com o tamanho das embalagens dos alimentos. Eram latas "gigantes" de massa de tomate, achocolatados e óleo; sacos de açúcar, feijão, arroz e farinhas; baldes plásticos com maionese, requeijão e molhos; caixas de papelão com biscoitos, pães e ovos. Essas embalagens despertaram grande interesse, não só pelo tamanho, mas, especialmente, porque uma das crianças reconheceu datas impressas no rótulo e questionou por que havia duas. Isso nos levou a selecionar as embalagens como um assunto para estudo. Combinamos que iriamos trazer caixas, sacos e potes vazios para estudar. A coleção de 
embalagens permitiu que as crianças reconhecessem os vários materiais que as compunham tais como: vidro, papel, aluminio, plástico, isopor, papelão, etc. Com este material as crianças foram estimuladas a fazer agrupamentos e reagrupamentos segundo a forma e composição das mesmas.

O estudo das embalagens levou a uma discussão sobre a proteção e limpeza dos alimentos e a importância de verificar as datas de fabricação e validade. A palavra validade, desconhecida para muitas, foi explicada por uma das crianças. Algumas não sabiam bem sobre os números referentes aos meses do ano. Com as embalagens foram revistos os meses e o sistema numérico para designá-los, permitindo que cada participante escolhesse uma delas para verificar e ler suas datas.

Os símbolos referentes à reciclagem chamaram a atenção de algumas crianças Com isso discutimos este conceito, deixando que as crianças os procurassem em suas embalagens. Elas contaram como muitas pessoas da comunidade coletam latas, vidros e papel para vender em um depósito que existe perto da favela. Envolvidos com as embalagens, entregando um modelo plano, em papel, sugeri que cada um recortasse e montasse sua embalagem, criando um produto, com datas de fabricação, validade e os símbolos de reciclável. Isso gerou várias caixas que ficaram expostas no clube.

O trabalho do semestre encerrou-se com a visita ao Museu de Etnografia da USP. Nele as crianças puderam ver os alimentos usados por outros povos, bem como adornos e objetos. A possibilidade de ver e observar os dioramas que mostravam a oca do índio e a cabana do caboclo, as vitrines com diversos objetos originários das diferentes culturasindigena, negra e européia - permitiu que as crianças fizessem comentários e reconhecessem similaridades com sua própria cultura. Elas tiveram oportunidade ainda de conhecer um pouco sobre as civilizações antigas como a egípcia e a grega. 


\subsubsection{A Cronologia do Trabalho: A Horta - Agosto de 99 a Junho de 2000}

O desenvolvimento da proposta educativa e didática incluída neste periodo refere às diferentes etapas que ocorreram simultaneamente no espaço fisico do clube e no local onde foi construída a horta, completando o ciclo de levantamentos para este estudo. A horta era a meta primeira dentro do elenco de assuntos propostos e estava sendo aguardada com muita expectativa por parte das crianças e da educadora.

Ainda na fase inicial do clube, durante uma visita das crianças à Sociedade Brasileira de Silvicultura (SBS), localizada próxima ao CJ, à Rua Marselha,1180, em conversa com a engenheira Andrea Maffeis, a entidade mostrou interesse em desenvolver um projeto voltado para a comunidade. Ao propor uma ação educativa em parceria, surgiu a possibilidade de usar o espaço da SBS para que as crianças construíssem sua horta. Para tanto, era preciso a apresentação de uma proposta por escrito. Isso gerou a criação de uma minuta apresentada e aceita pela SBS (Anexo 5).

Simultaneamente, no espaço físico do clube, iniciamos um estudo sobre a germinação de sementes a fim de que os educandos entendessem o processo e experimentassem com as diferentes sementes, identificando as estruturas, etapas e fatores responsáveis pela germinação. Esse estudo permitiu a construção de experimentos, do painel: SEMENTES QUE COMEMOS, e a organização de uma coleção com sementes. Assim, tínhamos dezenas de espécies de sementes de: alpiste, feijão branco, roxinho, feijão-de-corda (2 tipos trazidos pelas crianças), mamão, melancia, laranja, tomate, trigo e outras mais, o que permitiu desenvolver e produzir conhecimentos sobre o papel dessa estrutura na reprodução das plantas e sobre as sementes usadas na alimentação.

Os resultados obtidos com a germinação de sementes de feijão, milho, girassol e alpiste levaram as crianças a testar sementes torradas de abóbora, que tinham sido comidas enquanto discutíamos na roda. Como essas não germinaram, sugeri a questão: 
Vocès sabem por que as sementes de abóbora não germinaram? As crianças não conseguiram responder. Discutimos a respeito do aquecimento para torrar, o que levou as crianças a concluírem que as sementes são vivas e quando torradas, elas morrem (Anexo 6, Fig. 7)

Alguns acontecimentos inesperados e interessantes ocorreram com os frascos de germinação que, sobre a mesa, estavam mais distantes da janela. As plantas cresceram voltadas para a janela, mostrando que a luz é um fator importante para o desenvolvimento. Isso nos ajudou a definir, na horta, a localização dos canteiros, longe da sombra das árvores, e recebendo muita luz do sol.

Nos diferentes encontros reservamos tempo para registrar, com desenhos e escrita, as diversas etapas de germinação e anotar, em tabelas, as medidas de crescimento da raiz e do caule das plântulas, e também para conversar sobre as plantas e a horta. Nossas discussões abordavam sobre a germinação e o crescimento, os nutrientes, presentes na "massinha" do feijão (termo usado por eles para se referir aos cotilédones da semente), importante para nossa nutrição e a do "filhote" de planta. Um menino observou que, à medida que o "filhote" crescia, a "massinha" diminuía de tamanho, explicando que tal fato ocorria até que as plantas pudessem retirar, com suas raizes, o alimento da terra. Embora a idéia não seja completamente correta, ela faz parte do senso comum a respeito de como as plantas se alimentam. Neste momento aceitei a interpretação feita, retomando-a mais tarde, ao falar sobre a importância da luz para os vegetais e desenvolver a idéia de produção de alimento nas plantas (fotossíntese).

Como as crianças deveriam medir o comprimento das plantas com a régua e muitas não sabiam como utilizar o instrumento, foi explicado pela educadora a forma de uso e o significado das divisões. Auxiliada pelas crianças maiores, foi feito um atendimento individual àquelas que tinham dificuldade em reconhecer os centímetros e os milimetros. Havia ainda outro problema, que era usar a régua para medir plantas que não estavam eretas, com isso, algumas crianças passaram a usar, como artificio, um 
pedaço de barbante para medir, permitindo uma precisão melhor ao comparar o segmento de barbante com a régua. Isso resultou em valores decimais, que foram explicados com a ajuda das crianças mais adiantadas.

Nem todas as sementes plantadas germinaram. As crianças, decepcionadas, apresentaram seus resultados na roda. Foi um fato importante, pois as crianças foram estimuladas a buscar explicações para este resultado. Um dos meninos explicou que, talvez as sementes escolhidas estivessem estragadas - o que permitiu que se pudesse fazer uma comparação entre o esperado e o acontecido. De qualquer maneira, aquelas crianças foram estimuladas a refazer seus experimentos, testando a germinação de novos feijões ou outros tipos de sementes. Outras crianças também se interessaram em refazer experimentos, testando diferentes tipos de sementes que faziam parte da nossa coleção.

Os feijões "plantados" no papel filtro ou algodão, que estavam crescidos, foram transplantados para os copos com terra. Algumas plantas ainda permaneceram no algodão. Assim, as crianças puderam comparar as plantas na terra e no algodão, verificando que as que estavam na terra tornaram-se fortes e saudáveis. As do algodão, frágeis, pendentes e amareladas. Discutimos os resultados e foi concluído que na terra as plantas ficavam eretas porque a terra tem mais coisas que no algodão, como sais minerais e vitaminas.

Entusiasmadas com os resultados, algumas crianças procuraram nos livros didáticos, presentes na pequena biblioteca do $\mathrm{CJ}$, textos e esquemas sobre o assunto, trazendo- os para a roda. As crianças liam os trechos em voz alta e íamos comentando, completando, explicando as palavras mais dificeis, que não faziam parte do vocabulário. As próprias crianças explicavam os esquemas. Foi lido um outro livro A planta e o vento $^{2}$ encontrado por um dos garotos, que contava as mudanças sazonais de uma árvore, com a dispersão das sementes. O livro continha figuras muito bonitas e embora

\footnotetext{
${ }^{2}$ Silva LC. A Planta e o Vento. $2^{\text {a }}$ ed. São Paulo: Ática: 1989
} 
fosse uma história de ficção, exploramos a interpretação científica das imagens. $O$ desenho animado João pé de feijão foi assistido e as crianças comentaram sobre o filme, dizendo que conheciam a história de outra maneira. Cada um relatou sua versão.

A construção de textos coletivos, mais uma vez, levou as crianças a organizarem suas idéias, conceitos e termos. Consegue-se perceber que os textos, inicialmente mais simples, apresentavam-se agora mais organizados e complexos, com novos vocábulos incorporados.

Um assunto que interessou muito a todos foi a necessidade de alimentos para os seres vivos. Usando as plantas como referência e discutindo sobre a obtenção de alimentos, as crianças estabeleceram relações com o próprio corpo. Elas levantaram questionamentos que traduziam essas idéias: Para que servem os alimentos que comemos? O que acontece com os alimentos no nosso corpo? Que alimento são bons para nossa saúde? e Quais os que não precisamos comer? Um recorte de jomal com a figura de uma criança desnutrida foi passado de mão em mão. As crianças foram comentando sobre casos similares e fomos discutindo a questão da desnutrição. Foram vistos vários grupos de alimentos categorizados como: frutas e verduras; leite e derivados; carnes, peixes e ovos; cereais e legumes; e margarinas, manteiga, óleo e azeite. As crianças foram organizando cartazes com figuras recortadas de revistas. Foi explicado que cada grupo de alimentos fornece um tipo principal de material para nosso corpo, de modo que ele pode crescer, andar, correr, estudar, formar suas partes como a pele, a gordura e os músculos. Falamos sobre o alimento principal do bebê, o leite. Uma das meninas quis saber sobre o leite matemo, pedindo para explicar Como a mãe tem leite no peito?

A partir da aceitação pela Sociedade Brasileira de Silvicultura (SBS) do programa para a implantação da horta, iniciamos os planos e preparativos. Eles 
envolveram inicialmente o reconhecimento do terreno para a localização dos canteiros, a compra dos instrumentos e a escolha das sementes a serem utilizadas.

Ficou definido que a SBS construiria e prepararia os canteiros a partir do “estudo" das crianças. Visitamos o local com o grupo e escolhemos um canto do terreno que era bastante ensolarado. Munidos de estacas de madeira e barbante demarcamos uma área. Para tanto, foi feito antes um trabalho de medição usando os passos das crianças. Foram escolhidas propositalmente duas meninas de tamanhos diferentes. Foi pedido a elas que medissem o comprimento do canteiro usando seus passos. A menina mais alta contou um número menor de passos em relação à mais baixa. Ao desafiá-los para explicar o resultado e apresentar uma maneira que melhor medisse os canteiros, os alunos reconheceram que a diferença no número de passos estava relacionada à altura das garotas e sugeriram medir com a fita métrica. Questionei se a régua seria um bom instrumento. Alguns responderam que daria muito trabalho. Foi explicado que a fita métrica poderia ser usada, mas que havia um outro instrumento mais adequado. Um dos participantes lembrou aquele usado pelo pedreiro, mas não sabia o nome. Mostrei a trena, indicando o nome e as crianças passaram a usá-la definindo o tamanho dos canteiros (Anexo 6, Fig.8)

A questão das medidas ainda foi discutida pelo grupo, padronizando-se as medidas dos passos das alunas usando a fita métrica, calculando os valores e comparando com aqueles conseguidos com a trena. Foi contada às crianças um pouco da história das medidas, cujo padrão, na época, era definido pelos tamanhos do pé, do palmo e da largura do dedo do rei. Uma criança quis saber $O$ que acontecia quando $o$ rei morria?

Enquanto os canteiros iam sendo construídos, nossas reuniões passaram a ocorrer em função do planejamento da horta. Assim, discutimos o conceito e as características de uma horta, decidimos sobre o que plantar e estudamos o solos e sua irrigação. Ficou combinado que seriam compradas sementes de plantas das quais comemos: raízes 
(cenoura, beterraba); folhas (alface, couve, espinafre, repolho); frutos (melancia, maxixe, tomate, berinjela) e algumas para condimento (salsinha, cebolinha, manjericão). A definição dos vegetais nos levou a ler em um livro especializado sobre a época e forma de plantio, direto no chão ou em sementeiras.

As etapas do planejamento nos permitiram conduzir experimentos para verificar a condição de solo do local e a necessidade de adubo. Para tanto, as crianças testaram germinação com três tipos de solo: arenoso, terra preta adubada e vermelha (trazida do terreno da horta), chegando à conclusão de que o solo vermelho não era muito bom, pois as plantinhas crescidas nele ficaram menores do que aquelas plantadas em terra preta. Os estudos permitiram a observação dos solos em lupa e suas características físicas: cor, granulação e textura, organizando uma pequena coleção dos solos conseguidos. Foram montados, ainda, experimentos para estudar a permeabilidade, verificando que tipo "segurava" mais água. Neste periodo, foi iniciado o plantio nas sementeiras, do alface, do tomate, da berinjela e do repolho, pois estes vegetais não deveriam ser colocados direto nos canteiros.

Cada momento no clube era de aprendizado, o estudo dos instrumentos colocou em dúvida como se escreviam palavras. Enxada foi uma delas. Com $x$ ou ch? As dúvidas levaram algumas crianças a consultar o dicionário. Assim, foi explicado como deveriam proceder para encontrar as palavras, pois muitas não sabiam fazê-lo.

Leituras de textos específicos colocaram as crianças em contato com termos novos como agricultura, adubar, húmus, fértil e arar. Cada termo foi discutido e explicado, estimulando as crianças a entender o significado a partir do texto escrito e das ilustrações. A cada apresentação as crianças participavam, buscando nas suas vivências exemplos para ilustrar o que era falado.

Com os canteiros construidos passamos a trabalhar intensamente na horta Semana após semana, foram desenvolvidas as mais diversas atividades afofando a terra, 
colocando adubo, semeando, replantando, regando e removendo o mato e as pragas. As crianças, envolvidas e curiosas, verificavam o que brotou, observando o tamanho das plantas e fazendo os registros com desenhos. Os feijões transplantados, já grandes, estavam florindo e dando vagens, completando seu ciclo vital. Cada ida à horta era uma excitação, com novas descobertas e observações. Mesmo nas férias, quando as atividades cessaram, as crianças tentaram visitá-la, ou mesmo perguntavam sobre ela quando viam o funcionário responsável pela rega, naquele período.

O retomo à horta, após as férias, foi uma supresa, pois as plantas estavam viçosas e algumas no ponto de colher. A primeira colheita foi de espinafre e couve. Os pés de melancia, embora saudáveis, não tinham frutos, mas o maxixe sim. $O$ manjericão era perfumado, a salsinha, verdinha e os alfaces, comidos pelas pragas. Aos poucos os vegetais foram sendo colhidos. $O$ periodo das cenouras foi um sucesso. As crianças batiam palmas a cada cenoura arrancada. Novos canteiros foram montados. Dessa vez, semeando as plantas que germinaram melhor.

Neste período foram observados muitos animais, representados principalmente por insetos e caramujos. Chamou a atenção, em especial, um percevejo conhecido popularmente como "maria-fedida", da ordem dos hemípteros. Os percevejos estavam presentes em grande número e puderam ser observados pelo cheiro que exalavam, quando eram tocados. Um menino ficou bastante interessado em saber Como apareceram as "marias-fedidas"? Essa questão disparou uma curiosidade geral, tornando-se um assunto a ser estudado pelo grupo. Foram coletados alguns exemplares para observação. Com a ajuda de uma lupa manual e de livros especializados, tratamos de conhecer mais sobre a anatomia (número de patas, antenas, formas das asas e tipo de aparelho bucal), reprodução, habitat e alimentação. Descobrimos que algumas espécies de percevejos são pragas de plantações de maracujá e goiaba e que eliminam uma substância fétida como defesa, o que lhes confere um cheiro característico, cheiro de percevejo. Estudamos que alguns percevejos podem também transmitir doenças às pessoas quando chupam o sangue, enquanto elas dormem, transmitindo a doença de 
Chagas. E que as "marias-fedidas" fazem parte do mesmo grupo do barbeiro (causador da doença) e da barata dágua. Todas essas questões foram lidas e discutidas, com as crianças complementando com exemplos e idéias. Ao fím do estudo o próprio menino que levantou a questão no início, explicou que passa uma "maria-fedida", bota os ovos na horta, nascendo mais "marias-fedidas".

Outra praga presente foi uma grande quantidade de lagartas que apareceu em uma árvore junto aos canteiros. Os animais foram coletados e mantidos em um viveiro especialmente preparado, que permaneceu durante três semanas no clube. As crianças cuidavam das lagartas, querendo saber o que ia acontecer. Algumas arriscavam que elas se transformariam em borboletas, outras não tinham certeza. Discutia-se, então, de que cor seriam. Mesmo fora dos horários, ficou combinado que elas anotariam as modificações dos animais, trocando e umidecendo o algodão, colocando folhas novas para alimentação e retirando as pelotas de fezes. Descobrimos em um dos ramos, folhas com diminutos ovos. Destes nasceram pequenas lagartas. Mais um tempo e todas empuparam, transformando-se em borboletas amarelas e pretas. Cada etapa foi acompanhada de modo que as crianças puderam construir o ciclo de vida, reconhecendo a roda da vida como foi intitulado por um dos participantes. (Anexo 6, Fig. 9)

Os animais encontrados na horta permitiram que as crianças preparassem uma lista, onde foram incluídos não só os percevejos e lagartas, mas outros como formigas, minhocas, joaninhas, pulgões, caracóis, lesmas, borboletas, mariposas, moscas, e também uma perereca. Com estes materiais pudemos organizar exemplos de cadeias alimentares. O estudo da joaninha permitiu compreender a importância de alguns animais, ajudando o homem na remoção de pragas como os pulgões, que atacaram as nossas couves. A projeção do filme Microcosmos $^{3}$ ajudou a idenficar as fases do ciclo de vida dos insetos e a entender as relações existentes entre os vários componentes vivos e não-vivos do ambiente.

\footnotetext{
"Microcosmos: Fantástica Aventura da Natu reza (vol. 1). (viduo) Mundial Filmes
} 
A água usada na horta foi também um assunto discutido. As crianças sabiam que a água era elemento vital para as plantas, pois já tinhamos feito algumas experiências e tivemos um fracasso, quando em um fim de semana longo, as plantinhas de uma sementeira, localizada próximo à janela, tomaram sol direto, secaram e morreram. A discussão que se seguiu sobre a necessidade de água limpa, não só para as plantas da horta, mas para o nosso uso, permitiu que as crianças fizessem observações e reconhecimento de organimos ao microscópio, em gotas de água suja. O material, conseguido em um lago do campus da USP, foi ótimo pois vieram algumas baratas d'água, já mencionadas no estudo dos percevejos. As crianças estudaram e discutiram o funcionamento e limpeza do filtro d'água e a necessidade de fervura da água, quando ela está suja. Discutimos sobre as doenças relacionadas com a água contaminada como diarréia, hepatite e algumas verminoses. As crianças participaram relatando experiências pessoais, relativas a essas e outras doenças, e as formas como foram conduzidos os tratamentos. O uso do soro caseiro foi explicado por uma das meninas que tinha uma irmã menor doente. Como as crianças tinham recolhido fezes para exame, em um projeto da universidade Mackenzie, discutimos sobre a função desse exame e o uso da água limpa para a higiene, usando os esquemas de um livro. As crianças foram orientadas a cortar as unhas e aprenderam a lavar as mãos usando sabão e uma escova de unhas, para remover a sujeira. Essa forma de ação passou a ser conduta adotada cada vez que voltávamos da horta com as mãos sujas de terra.

Ao discutirmos sobre a questão da água, algumas crianças reclamaram a respeito do rodízio de água em funcionamento na cidade de São Paulo. Ao explicar a necessidade de racionamento de água pela falta de chuva, foi possível apresentar às crianças o ciclo da água. Todos se interessaram em saber de onde vinha a água que chegava na torneira de casa. Algumas arriscaram do rio Tietê. Aproveitamos para estudar o sistema de distribuição de água limpa e a captação de águas servidas através da rede ou fossa. As crianças contaram que na vila a água servida vai para um córrego da região. Este trabalho permitiu a preparação de painéis sobre o sistema de tratamento de água e a 
distribuição na rede, com as crianças apresentando seus painéis, os quais ficaram afixados nas paredes do clube

O trabalho com o microscópio teve uma preparação que antecedeu o seu uso. Foi explicada a origem do nome, suas partes principais e sua função para o estudo. As crianças nunca tinham visto o aparelho na realidade, embora algumas o conhecessem de nome. Elas se entusiamaram segurando as lâminas e lamínulas, acompanhando as explicações, enquanto eram preparadas as lâminas com gotas de água suja para observação. A utilização do instrumento permitiu que as crianças observassem imagens diferentes, de um mundo novo e desconhecido. Ele foi explorado com a preparação de outras lâminas, sugeridas pelos educandos, contendo materiais como folha, terra e cabelo. O microscópio gerou grande interesse e acabou por fazer parte de uma lista de pedidos, sugerida pelas próprias crianças à instituição (Anexo 6, Figs 10 e 11).

\section{Análise e Discussão sobre as Estratégias Utilizadas no Trabalho do Clube}

Embora este estudo trate de uma proposta voltada para a educação e promoção em saúde, ele envolve pressupostos pedagógicos, necessários e presentes em qualquer intervenção de ordem educativa. Eles são pertinentes à questão do ensino e da aprendizagem e permitem compor a análise dos dados conseguidos nos levantamentos de campo. Assim sendo, para essa discussão serão considerados os seguintes aspectos: objetivos; conteúdos; formas de trabalhos e respostas dos educandos; e interação educador/ educandos e dos educandos entre sí. Ainda que apresentados aqui como itens, para organizar e facilitar a análise, eles não devem ser entendidos separadamente, mas como um conjunto de propostas que se relacionam e interpenetram. 


\subsection{Os Objetivos}

As ações desenvolvidas pelo clube atingiram uma dimensão mais ampla sobre o significado de educação e ciência. Essa dimensão não tinha como meta apenas a informação, representada pelas noções e conceitos, mas era ampliada por outros objetivos, de ordem de concepção e filosofia educativas, que contemplavam o ciclo de aprendizagem, envolvendo habilidades, dentro de uma visão formativa, atingindo valores e atitudes e desenvolvimento de competências.

Sobre a alfabetização em Biologia, KRASILCHICK (2000, inf. pessoal) sugere o esquema representado abaixo

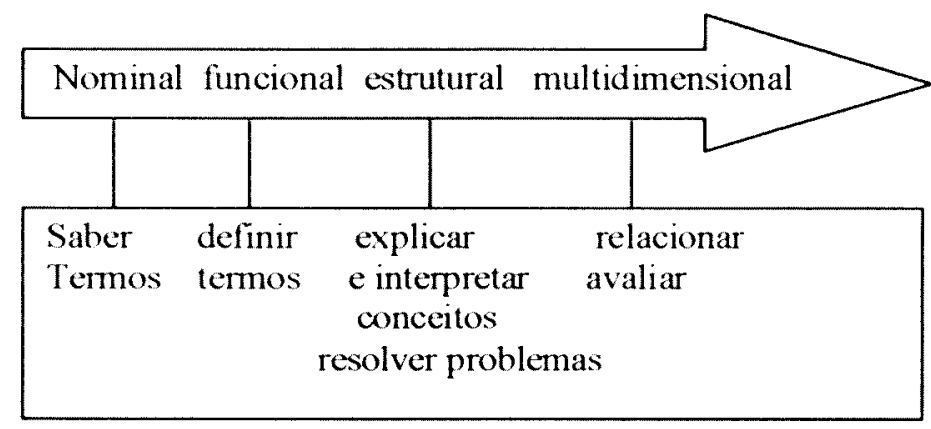

Figura 1. Níveis de alfabetização biológica (Seg. Krasilchik, M., inf. pessoal, modif.)

Na figura 1 estão presentes algumas das principais habilidades cognitivas, que devem ser contempladas pela ação educativa na disciplina Biologia, e que, na verdade, são perfeitamente válidas para o ensino de Ciências e Saúde. Como proposta central os conhecimentos devem atingir a multidimensionalidade, passando pelos níveis nominal, funcional e estrutural. Em cada uma dessas dimensões um certo número de categorias de habilidades cognitivas estão envolvidas. Essas vão se tomando mais complexas, possibilitando uma compreensão maior e mais profunda dos conceitos e permitindo que o educando aumente seu conhecimento, dando um salto em qualidade. Não podemos deixar de mencionar que no ensino de Ciências e Saúde, na maioria das vezes, o 
processo é centrado nos niveis nominal e funcional, sendo pouco contemplado o estrutural e raramente o multidimensional, razão pela qual o conhecimento se torna pobre e não significativo, pouco contribuindo para as implicações sociais da ciência, tendo como resultado um aprendizado inócuo e não revertendo em melhoria da qualidade de vida dos alunos (FROTA-PESSOA, 1976; TRIVELATO, 1986).

O trabalho, no universo da ciência, implica o desenvolvimento de formas de pensar, observar e interpretar o mundo, e de resolver problemas. Portanto, ao implantar o programa no $\mathrm{CJ}$, essas metas existiam na proposta. Assim, as sessões previstas no clube permitiram, como apresenta BLOOM et al. (1983), uma aprendizagem dos conhecimentos assentada principalmente no domínio cognitivo. No entanto, é evidente que os resultados encontrados também estiveram relacionados ao domínio afetivo (BLOOM et al., op. cit.), como mostram as entrevistas feitas com os educandos, presentes neste capitulo.

MEREDITH et al. (1997) afirmam que a educação não-formal, pelas suas características, facilita e oferece excelentes oportunidades para o aprendizado das Ciências. Os estímulos ao aprendizado nessa circunstância são diferentes daqueles apresentados no âmbito formal, escolar. Aqueles autores afirmam que, embora os objetivos educacionais no ensino possam potencialmente ocorrer nos três domínios de aprendizagem: cognitivo, afetivo e psicomotor, o trabalho não-formal, mais do que o formal, pode estar assentado principalmente no domínio afetivo.

KRATHWOHL et al. (1964), citados por MEREDITH et al. (1997, p. 806), descrevem os objetivos do aprendizado afetivo como aqueles que enfatizam a percepção, a emoção e o grau de aceitação ou rejeição. Enquanto para ELLIS e FONTS (1996) o domínio afetivo é visto como sendo área da educação que focaliza o desenvolvimento atitudinal/emocional dos estudantes, e de dificil medição (MEREDITH et al., 1997, p.807). MEREDITH et al. (op. cit.) concluem que a motivação é crucial para a resposta a fetiva e a satisfação ou frustação do aprendente, e é o principal determinante 
para a qualidade da experiência afetiva. O padrão dominante que emerge do estudo daqueles autores é que as interações sociais ao que parecem são vitais nas experiências educacionais não formais, de modo que o educadores responsáveis por este tipo de programa devem maximizá-las de modo significativo.

Podemos perceber quão complexo é o trabalho pedagógico, ao considerarmos que além dos conceitos, há atitudes, normas e valores a serem desenvolvidos. Neste sentido, COLL (1994) e ZABALA (1998) advogam que as atividades escolares só podem ser justificadas quando se considera que existam determinados objetivos do desenvolvimento pessoal que devem ser buscados nas atividades especialmente preparadas com este fim, ou seja, atividades que estão a serviço de um projeto educacional. Assim, para aqueles autores, de acordo com a posição adotada, uma maior ou menor ênfase pode ser centrada nas destrezas, habilidades, procedimentos, conhecimentos construídos socialmente, técnicas, métodos, formação de valores éticos e morais, atitudes sociais, etc. Os processos acima, pelo fato de serem aprendidos, são colocados por COLL (1994) e ZABALA (1998) na dimensão de conteúdos de aprendizagem. Este último autor categoriza os conteúdos em função do que os alunos devem saber, saber fazer e ser, intitulando-os, repectivamente, de conteúdos conceituais, procedimentais e atitudinais.

O ciclo de aprendizagem pelo qual passaram as crianças permitiu que elas explorassem materiais e organismos, muitos dos quais novos para elas. Ao manipular objetos, guiados por instruções e questões direcionadoras, idéias e conceitos foram gerados, enriquecendo suas interpretações e ampliando os esquemas explicativos, como afirma WEISSMANN (1998), relativizando as teorias espontâneas da criança. Houve também oportunidade de aplicar os novos conhecimentos e relacioná-los com suas vivências. Para o ensino de Ciências, HERRERA e THIER (1974) caracterizam esse ciclo como sendo um processo que envolve estágios de exploração, invenção e descoberta, garantindo não só a apreensão e ampliação do conhecimento, mas, sobretudo, dando significado ao que se aprende. Por outro lado, BENLLOCH (1984) 
enfatiza as teorias piagetianas para explicar a importância do recurso da invenção de experiências. Para a autora essa habilidade serve para demonstrar as afirmações e idéias das crianças, permitindo um jogo entre previsão, execução e resultados. A invenção estimula, portanto, um exercício intelectual que envolve a retroação, para que o conceito seja compreendido ( HERRERA e THIER, 1974; BENLLOCH, 1984).

SOLÉ e COLL (1998), ao tratarem do aprendizado significativo, didaticamente explicam, dentro de uma abordagem construtivista, que: aprendemos quando somos capazes de uma representação pessoal sobre um objeto da realidade ou conteído que pretendemos aprender. Essa representação é explicada não como um acúmulo de conhecimentos, mas como integração, modificação, estabelecimento de relações e coordenação entre os novos esquemas e os já construídos. Esses, por sua vez, apresentam organização e estrutura que dependem das relações criadas em cada momento de aprendizagem. Para aqueles autores a experiência pessoal e os conhecimentos de cada um determinam a interpretação que é realizada.

É, pois, tarefa do educador desenvolver as muitas capacidades particulares de pensar, não só no campo do conhecimento científico, mas também nos outros, uma vez que cada capacidade depende do material sobre o qual opera. Para VYGOTSKY (1988) desenvolver o intelecto significa desenvolver muitas capacidades especificas e independentes e formar muitos hábitos especificos.

\subsection{Os Conteúdos}

Podemos verificar através dos dados e registros apresentados que os conteúdos estudados, envolvendo conceitos e noções, foram bastante próprios e de interesse das crianças, especialmente aqueles relacionados à horta. No inicio dos trabalhos, apesar de envolvidas e curiosas, as crianças restringiram-se a ouvir e fazer o definido pela 
educadora, quase não contribuindo com sugestões e informações. Mesmo participando com interesse das atividades propostas, elas se sentiam envergonhadas quando encorajadas, ou mesmo quando questionadas sobre seus conhecimentos em determinado tema ou assunto. Com o tempo e o desenrolar dos trabalhos, as crianças foram manifestando seus interesses, idéias, opiniões e explicações.

Ao estruturar o currículo, definir os principais fatos a serem observados e conceitos a serem apreendidos, que contemplassem conhecimentos nas áreas de Ciências e Saúde, o pensamento voltou-se para a abrangência e a interdisciplinaridade. Na verdade, não se definiu uma sequência rígida, mas buscou-se estabelecer os conteúdos tendo a criança e seu mundo como foco. Havia, sim, preocupação com a organização dos conteúdos tendo como base o desenvolvimento dos educandos segundo as teorias piagetianas de aprendizagem. Era necessário, portanto, considerar as crianças (de 7 a 11 anos) dentro das respectivas etapas de desenvolvimento, pré-operacional (2-7 anos) e operatório-concreto (7-11 anos) (BEARD, 1978), considerando ainda, possivelmente, a não-vivência anterior na disciplina. Sem esse cuidado, haveria a possibilidade de estarse desenvolvendo um trabalho acima das possibilidades de compreensão e facção por parte dos educandos, o que levaria a desanimá-los.

WEISSMANN (1998) menciona o fato de que muitos professores das séries iniciais do ensino fundamental não ensinam conhecimentos cientificos aos seus alunos alegando que as crianças não têm condições mentais para estabelecer raciocínios indutivos e dedutivos, sendo incapazes de atingir o nível necessário para entendimentos conceituais. Em minha vivência como coordenadora na área de Ciências no ciclo básico, em escolas privadas, muitas vezes houve resistência por parte dos professores em trabalhar com determinados assuntos, especialmente aqueles relacionados à física e à química, pois eles consideravam-nos complexos demais para as crianças. $\mathrm{Na}$ verdade, concordo com WEISSMANN (1998) quando afirma, que o problema não está em justificar o que a criança não pode aprender, mas sim em apresentar conhecimentos que podem ser estudados, considerando: Como? e Por que aprender? Nessa perspectiva, é 
preciso considerar os conceitos e sua adequação, não devendo, portanto, ser retardada a aprendizagem

Em um estudo sobre o ensino de Ciências, elaborado com professores do ciclo básico da rede municipal de ensino, FREIRE (2000) encontrou dados que mostram que aqueles docentes reconhecem a precariedade na sua formação, afirmando não estarem preparados para atuar em sala de aula. Apesar disso, não encontravam dificuldades para o seu fazer profissional nas aulas da disciplina, ao escolherem conteúdos, estabelecerem relações com o cotidiano, selecionarem materiais e trabalharem os conteúdos conceituais. Possivelmente essa contradição se deva ao apoio do livro didático, que permite que o trabalho se processe, sem que as dificuldades de conhecimento se evidenciem

Todo ensino deve ter como proposta a transmissão de conhecimentos, ou seja, que educandos se apropriem de conhecimentos que ainda não possuem. Esses conhecimentos, entendidos por muitos educadores como conteúdos, englobam fatos, conceitos, generalizações e teorias. Porém, para outros educadores, como já discutido anteriormente, estão incluídos nos conteúdos não só os conceitos mas, também os procedimentos empregados para tratá-los.

Segundo a teoria de Piaget, a oferta de uma variedade de situações que permitam à criança experimentar e re-experimentar organiza suas estruturas mentais dentro do contexto, levando-as a reconhecer as propriedades de suas ações. BENLLOCH (1984), à luz dos estudo piagetianos, afirma que a criança não tem outro meio de reconhecer as propriedades de suas ações senão analisando a diferença que produz sua repetição em contextos diferentes. Assim, as diferenças acabam por informar o educando não só sobre a variedade de objetos sobre os quais atua, mas sobre as diferenças e semelhanças de suas ações no curso da sua aplicação sobre eles. 
BENLLOCH (op. cit.) afirma que trabalhos de lógica não devem essar restritos à matemática, mas presentes em outras situações envolvendo objetos e fenômenos, assegurando que a aprendizagem surja do exercicio da confrontação permanente com o novo, e não apenas da aplicação mecânica e de rotina.

\subsection{Formas de Trabalho e Respostas dos Educandos}

Questionamentos por parte dos educandos, envolvendo a curiosidade científica, eram raros nos encontros iniciais. A forma de atuação por parte da educadora, colocando muitas vezes questões que desafiavam as crianças a apresentarem seus esquemas explicativos e testarem suas idéias e pré-concepções, acabaram por provocar nos participantes, com o passar do tempo, a formulação de suas próprias perguntas. Essas, como se pôde ver, eram bastante pertinentes do "fazer cientifico". HERRERA e THIER (1974) afirmam que a forma como as questões são colocadas interfere no trabalho e nas atitudes das crianças. Assim, questões divergentes, pelo fato de se encaminharem em várias direções, permitindo diferentes respostas, são provocativas e estabelecem discussões

Atividades variadas envolvendo a atuação direta sobre diferentes objetos, o manuseio de materiais e a preparação de experimentos permitiram a exploração, a descoberta e a invenção, etapas importantes no aprendizado de ciências. As atividades desenvolvidas no Clube estimularam as crianças a trazerem "coisas" como sementes, plantas e embalagens, enriquecendo o trabalho e o espaço, e explicitando seu envolvimento com o projeto.

Interessante observar a questão do desenvolvimento da linguagem oral, uma vez que o vocabulário do mundo científico é tão próprio. Preocupada não só com a quantidade, mas em especial com a qualidade da linguagem, vocábulos novos encontrados nos textos e/ou falados na roda foram apresentados, escritos na lousa e em 
tiras de cartolina e ficaram afixados na parede do clube. As crianças eram estimuladas a usarem aqueles termos durante suas explicações e apresentações orais. A possibilidade de relatar vivências, histórias e observações permitiram, ainda, mais comunicação entre as crianças e a utilização de uma linguagem mais precisa, provocando interações e integrando os componentes do grupo.

É preciso mencionar a questão do uso de textos para completar e complementar os estudos. Havia por parte da educadora uma preocupação na seleção de materiais impressos em livros didáticos e paradidáticos, revistas e jomais, que pudessem ajudar na explicação e compreensão dos conceitos, ou que mostrassem a aplicação dos conhecimentos. Com o tempo, algumas crianças passaram a trazer para a roda livros encontrados, durante a semana, na pequena biblioteca do CJ. Sempre havia textos, figuras e histórias referentes aos assuntos que estavam sendo estudados e que haviam sido selecionados pelas próprias crianças. Estes eram passados de mão em mão, lidos e discutidos na nossa roda. Temos que considerar que a diversidade de formas de expressão permite trabalhar a criatividade, componente fundamental no trabalho com crianças.

Neste sentido, podemos citar o trabalho de CARVALHO et al. (1998), que aplicaram um programa na área de Ciências para crianças do ciclo básico. Os autores estabeleceram um trabalho integrado com a disciplina Lingua Portuguesa, desenvolvendo além dos conteúdos de física a capacidade de expressão das crianças, propiciando a aquisição de novos vocábulos e o aprendizado de novas grafias.

A construção de registros foi outra preocupação nos trabalhos estabelecidos no clube. Eles tinham como objetivo principal fixar e sistematizar os conteúdos vistos. Assim, os registros acabaram por fornecer indicios de quanto c como as crianças captaram e processaram as informações. Uma amostra desses registros está presente neste capítulo dando uma dimensão do trabalho e da qualidade de representações das crianças. Muitas apresentaram resistência com o registro escrito, em especial, aquelas 
com grande comprometimento na alfabetização da língua. Mesmo assim, participaram da construção de textos coletivos, contribuindo com idéias e desenhos, buscando retratar aspectos dos conceitos estudados. Os textos mais simples no início, sob orientação, foram se organizando e tornando-se mais completos, com a incorporação de alguns dos novos vocábulos. Em geral, as crianças envolviam-se com muito interesse em atividades de desenho e pintura. O uso desse recurso tem sido usado para estudos, mostrando ter um grande poder para romper barreiras, permitindo que as emoções sejam expressadas, como afirma PRIDMORE (1996).

Ao planejar o trabalho a ser desenvolvido, a idéia de ensino ativo esteve presente na proposta, em todos os momentos. É importante abrir um espaço para explicitar e discutir essa concepção, pois ela é usada de modo equivocado por muitos professores que consideram que os educandos estão ativos pelo fato de estarem preenchendo fichas e efetuando tarefas. Na verdade, o termo tem outro significado, e CLAPARĖDE (1973), citado por COLL (1994, p.46-47), sugere substituí-lo por atividade funcional, diferindo da atividade de efetuação. Para aquele autor, a atividade de efetuação é apenas a ocupação do educando com a execução de atividades, enquanto a funcional implica em interesse, por parte do aprendente, pelo ato que realiza. CLAPARÈDE (op. cit.) afirma que o processo educacional ativo engloba três fases: instigar o interesse mediante as situações propicias; surgimento das reações adequadas para satisfazer o interesse; $e$ aquisição dos conhecimentos necessários para controlar e dirigir essas reações. Para completar e enriquecer a noção, COLL (1994) junta o conceito de atividade autoestruturante de Piaget. Nela, o aluno tem autonomia para organizar e estruturar sua ação. $O$ referido autor explica que a atividade funcional permite que o aluno decida $o$ que fazer e a estruturante permite que o aluno decida como fazer, atuando de maneira bastante diferenciada, com autonomia.

As crianças do clube estiveram frente a situações que as conduziram em atividades funcionais e também de efetuação, com algumas auto-estruturantes. Essas últimas surgiram no transcorrer dos vários encontros, a partir de vivências e 
experiências, com a manifestação, por parte de algumas, sugerindo atuações. É preciso considerar as condições educativas a que normalmente estão submetidas essas crianças, seja na escola ou fora dela, onde o estímulo para o aprendizado no nível autoestruturante é bastante frágil e quase inexistente, sem qualquer autonomia, em especial na aprendizagem de Ciências. Portanto, frente à realidade educativa, os resultados obtidos com os participantes do clube foram promissores. Autonomia só é obtida a partir do conhecimento e do aumento da confiança em si mesmo, que acabam por conferir ao aluno clareza e certeza do que faz.

A preocupação constante da educadora era propor e organizar condutas educativas, muitas vezes disparadas a partir das relações reflexivas e de questionamentos sobre os objetos e fatos. Essas desafiavam as crianças e tinham como proposta desencadear buscas e respostas, permitindo a requisição e vivência das habilidades cognitivas, de destreza e de comunicação, atingindo uma dimensão construtiva para a aquisição de conhecimento. Isso permitiu que elas desenvolvessem, simultaneamente, o espirito para Ciência, que thes permitin o acesso a processos intelectuais, sociais e afétivos (BENLLOCH, 1984), e o aumento da confiança em si mesmas, buscando atingir a autonomia. Hoje, estando ainda com as crianças que iniciaram o programa, sinto-as fortalecidas, o que se evidencia pela sugestão mais freqüente de ações e condutas dentro do "fazer cientifico".

O processo construtivo dos conhecimentos, nas diversas ações educativas praticadas, envolveu especialmente o nível concreto, dirigindo nossos esforços dentro das técnicas concretas e imaginativas, preparando o caminho para as técnicas formais, na dimensẫo hipotéticodedurivo (BEARD, 1978). Buscando o que COLL (1994) denomina de formação de atitude cientifica e experimental, foram consideradas as dimensões criativa e imaginativa, permitindo que as crianças apresentassem suas maneiras de pensar, testando suas "teorias". SIGNORELLI (s.d.) chama atenção para essa atuação, afirmando que ela proporciona autonomia de pensamento ao permitir que os educandos apresentem soluções não usuais ou, até mesmo, incompativeis com a 
ciência atual, o que, no entanto, não diminui a qualidade de atuação. Assim, possibilitar às crianças operarem e experimentarem com a realidade cientifica do clube, na dimensão concreta e com aporte no nivel hipotético-dedutivo, permitiu o pensar, descobrindo a lógica dos fenômenos, bem como a ação necessária aos objetos para que se tornassem inteligiveis. A ação pedagógica criou condições para que as informações percebidas pela criança tornassem um objeto de conhecimento em um observável (CAVALCANTI, 1995). Assim, permitiu-se que as crianças transformassem suas vivências em objetos de estudo, ampliando, construindo e reconstruindo seus conhecimentos.

É preciso mencionar que nem todo conhecimento pode ser construído pela criança, e ele não é construído apenas com sua ação sobre os objetos e fatos, como pensam muitos professores. Simplificando, explicamos que Piaget estabelece que a ação do sujeito sobre o objeto origina dois tipos de conhecimentos que são dependentes e não necessariamente adquiridos em sucessão: o empírico, de alto grau exógeno, e o lógicomatemático, de caráter endógeno. A interação do sujeito sobre o objeto se desdobra, permitindo a conexão por oposição dialética entre as contribuições do sujeito e do objeto. Dessa forma, a interação permite a construção da realidade, emanada do conhecimento empírico, e da coordenação de suas ações, empregadas para compreender essa mesma realidade, sendo essa última emanada do conhecimento lógico-matemático (BENLLOCH,1984). Como se vê, é ingênuo imaginar que apenas a partir da ação empírica a criança possa construir seu conhecimento. A presença do educador como formalizador e sistematizador é, sem dúvida, essencial. KAMII e DEVRIES (1986) atribuem papel mais importante ao professor como fonte de conhecimento do que como fornecedor de materiais e criador de "contextos estimulativos". 


\subsection{Interação Educador/Educandos e dos Educandos Entre Si}

As relações interpessoais estabelecidas nos primeiros encontros com os participantes do clube foram se firmando e aprofundando, dando consistência às interações de ensino-aprendizagem.

Não há dúvidas a respeito da importância da comunicação na interação educador e educando. KRASILCHIK (1986) discute a questão dos obstáculos encontrados quando há incompreensão e falta de interação entre o professor e o aluno. Essa incompressão pode residir na presença de vocabulário desconhecido por parte do aluno e o uso exagerado de termos técnicos por parte do professor. Em vista disso, foram tomados cuidados, de forma que os novos vocábulos introduzidos, especialmente os técnicos, fossem bastante explicados e as crianças estimuladas a usá-los em seus contextos. Encorajadas a organizar suas experiências e a participar das discussões e debates, as crianças sentiram-se motivadas e estimuladas, trocando espontaneamente, idéias e observações e comparando seus dados. Essa interação permitiu a socialização de conhecimentos, com a partilha de informações e idéias.

A respeito das trocas exitentes entre as crianças, podemos nos reportar ao programa de educação em saúde, proposto pela UNESCO, denominado Atividades Criança-a-Criança, voltado para o ensino de ciência e tecnologia. A proposta tem como princípio central, dentro do processo de ensino e aprendizagem, a interação entre os educandos, reconhecendo outro papel desempenhado por eles, o de ensinantes. Assim, ao aprender, a criança é estimulada a se cuidar e ajudar outros a aprenderem, aplicando e transmitindo seus conhecimentos (HAWES,1988; UNESCO,1991).

Nos trabalhos evitou-se o uso de apresentações expositivas, centradas no professor, mas, ao invés, buscou-se com trabalhos ativos e sistemáticos apresentar questões que estimulassem, o estabelecimento de interações dialógicas entre todos, educador e crianças, distanciando-se da aula tradicional e do verticalismo.A propósito, a 
atuação se aproximou do que HURTADO (1993) discute a respeito da metodologia de ensino para a educação popular. $O$ referido autor caracteriza a atuação neste ensino como uma forma diferenciada, superando a "aula" e buscando uma relação educadorleducando fora do modelo verticalizador como um fato escolar, onde quem sabe informa e "educa" quem não sabe. Ao invés da rotina tradicional a interação entie prática e teoria, ocorrendo de modo contínuo e sistemático, impulsionado e acompanhado por aqueles que têm maior nivel e capacidade de análise, reflexão e informação.

Explicando os níveis de comunicação, HURTADO (op. cit.) chama a atenção para uma forma privilegiada de enriquecimento mútuo, o diálogo. Ocorrendo nos níveis interpessoal, grupal, coletivo e/ou massivo, ele requer método e apoio de materiais didáticos, que favoreçam a comunicação constante e sistemática entre os vários participantes. Esses níveis não se excluem mas, segundo o autor, estão presentes no processo educativo, complementando-se e dando reforço e eficiência ao sistema de comunicação.

A possibilidade de exposições dialogadas, apresentando questões que desafiem as crianças na apresentação de suas experiências e na comparação e confrontação de suas observações, ajudam no raciocínio e motivam a apresentação de suas idéias (HERRERA e THIER, 1974; KRASILCHIK,1986).

BENLLOCH (1984) discute, ao analisar a ação do professor frente às teorias de Piaget e a respeito do momento adequado para ensinar determinadas noções, a importância do desenvolvimento intelectual da criança, apontando que ela é função indispensável das interações sociais estabelecidas com outras crianças e com o adulto Chamando atenção para a riqueza e variedade de conhecimentos no estudo da natureza, a autora completa que a divergência de explicações dos alunos constitui um motivo de aprendizagem dupla: a criança aprende a verificar que sua opinião é uma no conjunto de opiniões coletivas e enriquece suas concepções com as dos demais colegas. 

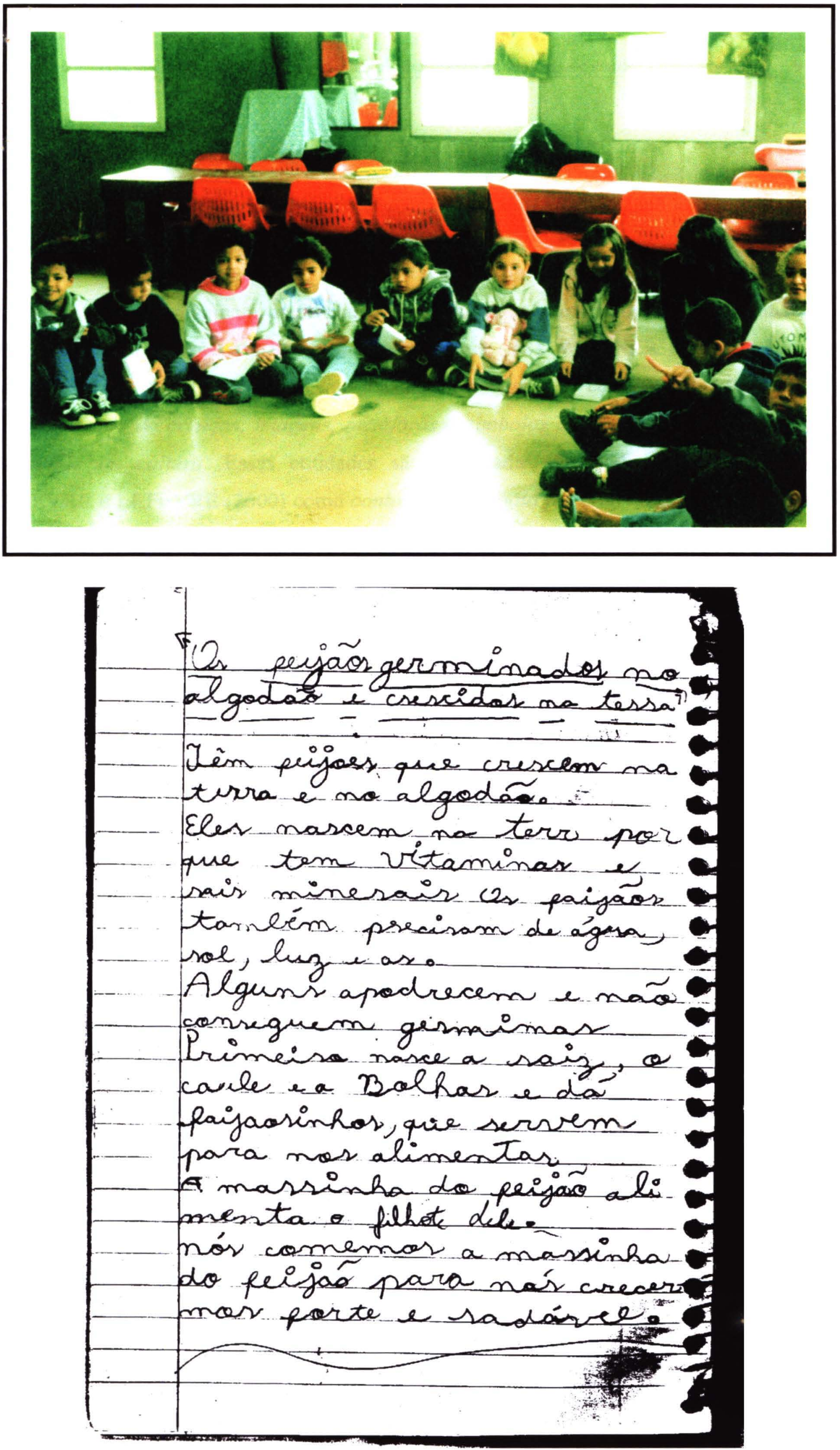


\section{Os Participantes e seus Discursos}

$\mathrm{Na}$ abordagem qualitativa, uma das maneiras de conhecer a realidade e o que pensam, sentem e imaginam os participantes sobre o tema e/ou trabalho compartilhado pode ser obtida através das Representações Sociais (RS). WAGNER (1998) explica, dentro da dimensão subjetiva, que as RS formam um conjunto coletivamente compartilhado de crenças, imagens, metáforas e simbolos de um grupo, comunidade, sociedade ou cultura. Essas entidades são explicadas de modo simplificado por LEFÈVRE e LEFÈVRE (2000) como conhecimento muito próximo da ação cotidiana $e$ que tem a função de guiar, orientar e justificar essa ação. Estes últimos apontam que as RS podem ser estruturadas a partir do discurso ou pensamento encadeado.

As formas como são concebidas as RS podem ser obtidas, entre outras maneiras, através dos discursos orais manifestados e consideradas sob três dimensões: descritiva, interpretativa e evolutiva

\subsection{As Crianças}

Nessa pesquisa, a busca e análise das RS a partir de depoimentos obtidos em entrevistas permitiram levantar indícios concretos de como os educandos viam e se relacionavam ao trabalho do clube, fornecendo ainda dados sobre sua ação educativa e extensão no cotidiano familiar e no ensino formal.

Foram convocadas 32 crianças para as entrevistas, porém algumas tiveram dificuldades em responder as questões. Essas, em geral, permaneceram caladas pressando atenção e, muitas vezes, manisfestavam-se concordando com a cabeça à medida que os colegas falavam. O discurso de um foi o discurso do outro, (vide Quadro 3). 


\section{Quadro 3. Depoimentos das Crianças}

Questões: Vocês gostam de aprender sobre Ciências? Por quê?

Vocess acham importante o trabalho do Clube? Por quê?

\begin{tabular}{|c|c|c|}
\hline SUJEITO & IDEIA-CENTRAI & EXPRIESSÃO-CHAVE \\
\hline 1 & $\begin{array}{l}\text { Eu gosto porque tem coisa nova. Estudar } \\
\text { alfabetiza, ajuda a fazer uma faculdade, onde } \\
\text { se aprende tudo e ai se pode conseguir } \\
\text { emprego. }\end{array}$ & $\begin{array}{l}\text { Eu gosto porque tem coisa nova. Quando for } \\
\text { faculdade né, vão ter de tudo... o que nóis nem } \\
\text { sabe, nem lê, nem escrevê, né...tá bom pra tê } \\
\text { emprego. Quando nóis entra numa oficina, } \\
\text { né...igual ao meu pai, ele entrou numa firma, } \\
\text { não sabia lê, nem escrevê... os caras perguntou } \\
\text { e ele nem sabia lê e nem escrevê... }\end{array}$ \\
\hline 2 & $\begin{array}{l}\text { Estudar me ajuda a ser bom aluno e ter melhor } \\
\text { aproveitamento. (Saber) é importante na } \\
\text { entrevista para conseguir um emprego. }\end{array}$ & $\begin{array}{l}\text {...quando a gente crescê os caras vão pegar } \\
\text { nossas provas pra ver se a gente melhorou....se } \\
\text { a gente é bom...e aí é bom estudá ...importante } \\
\text { pra quando eles vão perguntá que número a } \\
\text { gente sabe e o que a gente num sabe. Eles } \\
\text { pergunta romano, ninguém sabe eles mandam } \\
\text { a gente embora, ai a gente fica na rua igual os } \\
\text { outros. }\end{array}$ \\
\hline 3 & $\begin{array}{l}\text { Permite escrever sobre os conhecimentos na } \\
\text { prova. }\end{array}$ & $\begin{array}{l}\text {..porque a gente fala sobre eles } \\
\text { (conhecimentos de Ciências e Saúde) na prova. }\end{array}$ \\
\hline 4 & $\begin{array}{l}\text { E legal, porque a gente aprende mais e na } \\
\text { escola nunca teve Ciências. }\end{array}$ & $\begin{array}{l}\text { É legal...porque a gente aprende mais...porque } \\
\text { na escola nunca teve Ciências. }\end{array}$ \\
\hline 5 & Ei legal Aprende muitas coisas. & E legal ...aprende muitas coisas $\ldots$ \\
\hline 6 & É legal liu não sabia plantar, agora sei. & $\begin{array}{l}\text { É legal ...eu não sabia plantá feijão, agora sei. } \\
\text { (continua) }\end{array}$ \\
\hline
\end{tabular}




\begin{tabular}{|c|c|c|}
\hline & & (continuação-Quadro 3 ) \\
\hline 7 & $\begin{array}{l}\text { Tem coisas que a gente nunca aprendeu na } \\
\text { escola e aprende aqui. }\end{array}$ & $\begin{array}{l}\text { Tem coisas que a gente nunca aprendeu na } \\
\text { excola c aprende aqui. }\end{array}$ \\
\hline 8 & $\begin{array}{l}\text { E legal, porque gosto de aprender wobre os } \\
\text { nutrientes, de explorar e de saber wobre o } \\
\text { corpo. }\end{array}$ & $\begin{array}{l}\text { l: legal, porque eu gosto de aprender sobre os } \\
\text { nutrientes e pra explorar...pra saber sobre o } \\
\text { nosso corpo... }\end{array}$ \\
\hline 9 & $\begin{array}{l}\text { É bom, porque aprende muita coisa. Aprender } \\
\text { oduca e ajuda a não ficar doente. }\end{array}$ & $\begin{array}{l}\text { E bom, porque aprende muita coisa...pra não } \\
\text { ficar mal oducado...pra não ficar doente. }\end{array}$ \\
\hline 10 & É bom, porque cuidamos da saúde. & É bom, porque cuidamos da saúde. \\
\hline 11 & Faz parte da nossa vida. & Faz parte da nossa vida \\
\hline 12 & Faz parte da nossa higiene. & Faz parte da nossa higiene \\
\hline 13 & $\begin{array}{l}\text { E legal, porque aprendemos muitas coisas } \\
\text { sobre as plantas, o corpo e os alimentos. } \\
\text { Procisamos saber sobre o corpo e os alimentos. }\end{array}$ & $\begin{array}{l}\text { E legal, porque a gente aprende mais coisa } \\
\text { e...das plantas, do corpo..., um monte de } \\
\text { coisas...Ah! acho que a gente tem de saber do } \\
\text { corpo...e os alimentos... }\end{array}$ \\
\hline 14 & $\begin{array}{l}\text { Acho bom, porque a gente aprende muitas } \\
\text { coisas. (Aqui se) fala sobre o corpo e do } \\
\text { pulmão }\end{array}$ & $\begin{array}{l}\text { Acho bom, porque a gente aprende mais... fala } \\
\text { do corpo...do pulmão, né? Acho bom...não sei } \\
\text { porque... }\end{array}$ \\
\hline 15 & $\begin{array}{l}\text { Eu gosto porque é muito interessante e se } \\
\text { aprende muita coisa. }\end{array}$ & $\begin{array}{l}\text { Eu gosto porque é muito interessante... a gente } \\
\text { aprende muita coisa... }\end{array}$ \\
\hline 16 & $\begin{array}{l}\text { Porque a gente aprende coisas, sobre as plantas } \\
\text { e o solo. Voce tem que lembrar das coisas } \\
\text { aprendidas na escola. Quando eu for } \\
\text { professora, eu vou educar meus alunos, mesmo } \\
\text { os piores e vou me lembrar das cusisis yue voce } \\
\text { ensinou. }\end{array}$ & $\begin{array}{l}\text {...porque a gente aprende... sobre a plantas...as } \\
\text { terra... No passado você tem que se lembrá das } \\
\text { coisas que aprendeu na escola...colocar na } \\
\text { cabeça um pouquinho de cada coisa. Quando } \\
\text { for profesiora, eu vou educa meus alunos, } \\
\text { (continua) }\end{array}$ \\
\hline
\end{tabular}




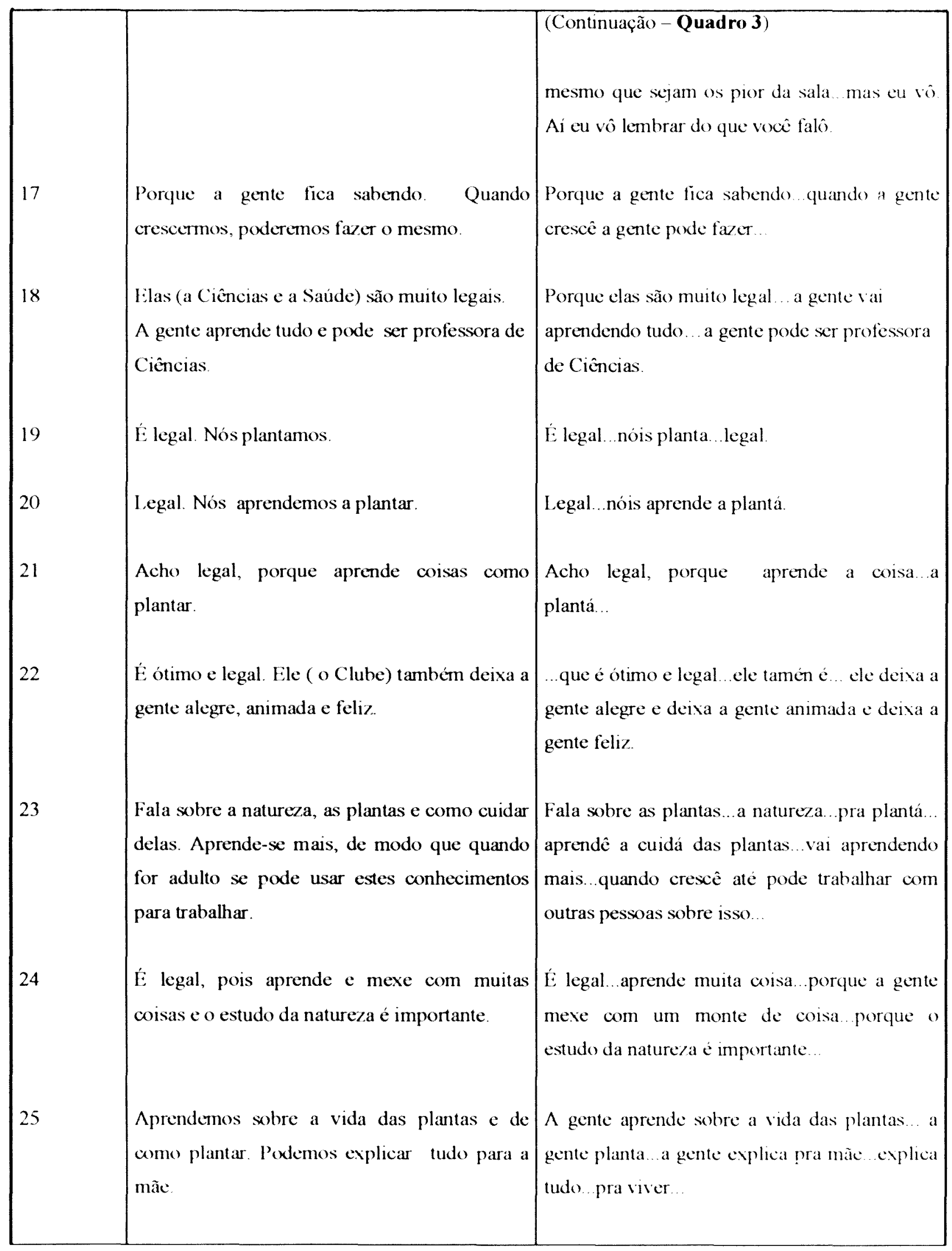


Assim, na dimensão descritiva, analisando os discursos de um conjunto de indivíduos submetidos à uma mesma circunstância, foi possível resgatar e identificar as idéias, opiniões e sentimentos para estruturar os modos de pensar e interpretar das crianças frente ao trabalho educativo apresentado. Para BOURDIEU (1990), citado por LEFÈVRE e LEFÈVRE (2000, p. 19-20) os indivíduos atuam como uma categoria que detém habitus e representações semelhantes, que se traduzem em determinadas práticas sociais e modalidades de discurso que as expressam.

Usando-se as figuras metodológicas, expressão-chave e idéia-central, puderam-se organizar as informações presentes nos discursos das crianças e estruturar o Discurso do Sujeito Coletivo (DSC).

As expressões-chave, organizadas a partir da própria fala da criança e a idéiacentral, que traduziu o sentido da fala, revelaram a essência do sentido da resposta, como afirma LEFÈVRE e LEFÈVRE (2000). Essas últimas foram posteriormente agrupadas e categorizadas segundo suas similaridades, fornecendo as seguintes categorias de discursos:
a) afetivo;
b) do algo novo e não visto na escola;
c) da ampliação e aplicação do conhecimento;
d) da formação profissional, acesso à universidade e garantia de emprego;
e) do reforço escolar.

De posse dessas categorias, foram construídos os DSCs, representando estes os discursos-sintese dos sujeitos envolvidos.

E importante salientar que tais discursos não são vistos como a soma de pensamentos, mas representam de modo coletivo o pensamento de um grupo definido, 
cuios participantes, presentes no mesmo tempo e espaço, estavam submetidos a uma mesma ação educativa.

Os diferentes discursos obtidos forneceram uma dimensão legitima do trabalho desenvolvido, tendo como foco o "olhar" dos educandos, a partir da ação educativa desempenhada pelo clube. Estes serão analisados e discutidos a seguir.

a) afetivo

\section{Quadro 4. Depoimentos da categoria "afetivo"}

Questões: Vocês gostam de aprender sobre Ciências? Por quê"?

Vocês acham importante o trabalho do Clube? Por quê?

\begin{tabular}{|c|c|c|}
\hline SUJEITO & IDELA-CHNIRAL & EXPRESSÃO-CHAVE: \\
\hline 4 & $\begin{array}{l}\text { E legal, porque a gente aprende mais e na } \\
\text { escola nunca teve Cièncias. }\end{array}$ & $\begin{array}{l}\text { E legal . porque a gente aprende mais . porque } \\
\text { na escola nunca teve Ciências. }\end{array}$ \\
\hline 5 & É legal. Aprende muitas coisas. & E legal aprende muitas coisas... \\
\hline 6 & É legal. Eu não sabia plantar, agora sei. & É legal...eu não sabia plantá feijão, agora sei. \\
\hline 8 & $\begin{array}{l}\text { E legal, porque gosto de aprender sobre os } \\
\text { nutrientes, de explorar e de saber sobre o } \\
\text { corpo. }\end{array}$ & $\begin{array}{l}\text { E: legal, porque eu gosto de aprender sobre os } \\
\text { nutrientes e pra explorar...pra saber sobre o } \\
\text { nosso corpo.. }\end{array}$ \\
\hline 9 & $\begin{array}{l}\text { E: bom, porque aprende muita coisa Aprender } \\
\text { educa e ajuda a não ficar doente. }\end{array}$ & $\begin{array}{l}\text { E bom, porque aprende muita coisa pra não } \\
\text { licar mal cducado pra não ficar docnte. }\end{array}$ \\
\hline 10 & I: bom, porque cuidamos da saude. & $\begin{array}{l}\text { li bom, porque cuidamos da saude. } \\
\text { (Contmua) }\end{array}$ \\
\hline
\end{tabular}




\begin{tabular}{|c|c|c|}
\hline & & (Continuação-Quadro 4) \\
\hline 13 & $\begin{array}{l}\text { É legal, porque aprende muitas coisas sobre } \\
\text { as plantas, o corpo e os alimentos } \\
\text { Precisamos saber sobre o corpo e os } \\
\text { alimentos. }\end{array}$ & $\begin{array}{l}\text { E. legal, porque a gente aprende mais coisa } \\
\text { e das plantas, do corpo..., um monte de } \\
\text { coisas Ah! acho que a gente tem de saber do } \\
\text { corpo e os alimentos... }\end{array}$ \\
\hline 14 & $\begin{array}{l}\text { Acho bom, porque a gente aprende muitas } \\
\text { coisas. (Aqui se) fala sobre o corpo e do } \\
\text { pulmão. }\end{array}$ & $\begin{array}{l}\text { Acho bom, porque a gente aprende mais...fala } \\
\text { do corpo... do pulmão, né? Acho bom . não sei } \\
\text { porque... }\end{array}$ \\
\hline 15 & $\begin{array}{l}\text { Eu gosto porque é muito interessante e se } \\
\text { aprende muita coisa. }\end{array}$ & $\begin{array}{l}\text { Eu gosto porque é muito interessante... a } \\
\text { gente aprende muita coisa... }\end{array}$ \\
\hline 19 & É legal. Nós plantamos. & É legal nó is planta legal \\
\hline 20 & Legal. Nós aprendemos a plantar. & Legal...nóis aprende a plantá. \\
\hline 21 & $\begin{array}{l}\text { Acho legal, porque aprende coisas como } \\
\text { plantar. }\end{array}$ & $\begin{array}{l}\text { Acho legal, porque aprende a coisa...a } \\
\text { plantá... }\end{array}$ \\
\hline 22 & $\begin{array}{l}\text { É ótimo e legal. Ele (o Clube) também deixa } \\
\text { a gente alegre, animada e feliz. }\end{array}$ & $\begin{array}{l}\text {...que é ótimo e legal...ele tamén é... ele deixa } \\
\text { a gente alegre e deixa a gente animada e deixa } \\
\text { a gente feliz. }\end{array}$ \\
\hline 24 & $\begin{array}{l}\text { E legal, pois aprende e mexe com muitas } \\
\text { coisas e o estudo da natureza é importante. }\end{array}$ & $\begin{array}{l}\text { E: legal...aprende muita coisa...porque a gente } \\
\text { mexe com um monte de coisa...porque o } \\
\text { estudo da natureza é importante... }\end{array}$ \\
\hline
\end{tabular}

\section{Discurso do Sujeito Coletivo:}

“É legal e ótimo, porque a gente vai aprendendo muitas coisas, vai aprendendo tudo. $E$ interessante aprender, saber, mexer e explorar sobre os nutrientes, as plantas, nosso corpo e a saide. O trabalho deixa a gente alegre, animada e feliz." 
É bastante evidente nos discursos apresentados a relação afetiva estabelecida entre os educandos e o clube. As crianças foram unânimes em afirmar que gostavam muito do trabalho, usando termos como legal, bom e ótimo (vide Quadro 4)

O espaço era vivo e cheio de "coisas para fazer". As crianças eram efetivamente ativas, desempenhando funções e ações combinadas e definidas previamente, muitas delas sugeridas por elas próprias. Assim, estavam envolvidas nas mais variadas modalidades e estratégias didáticas de atuação. Essas estratégias convocavam não só de maneira ativa, mas principalmente cooperativa a participação de todos. Eram evidentes o interesse despertado nas crianças e o prazer com que executavam as tarefas

Atividades como contar histórias, assistir a filmes, jogar, preparar experiências cientificas, organizar coleções, preparar painéis e visitar museus e instituições deram um caráter lúdico ao trabalho, permitindo estabelecer as ligações afetivas. Não só nas entrevistas, mas durante todo o processo, as crianças verbalizaram seu prazer e interesse pelo trabalho. Isso foi visivel no envolvimento e ação para cuidar de experimentos que requeriam continuidade e assiduidade como a germinação de sementes, o crescimento de plantas e a alimentação dos animais em viveiros. $\mathrm{O}$ mesmo deu-se quanto ao interesse de registros sobre os acontecimentos que ocorriam fora do horário de atividades.

KRASILCHIK (1986) chama atenção para as modalidades didáticas, apontando que a escolha depende não só dos conteúdos, do tempo e dos recursos, mas também dos objetivos selecionados e do grupo. A autora mostra a importância de se incluir uma diversidade de estratégias didáticas, cada uma exigindo solução própria, como forma de atrair e interessar os alunos, contemplando as diferenças individuais. KRASILCHIK (1986, p.55) categoriza as modalidades, baseando-se em critérios propostos por ASCHER(1966), como as que falam, fazem e mostram, permitindo com elas a transmissão de informações e o desenvolvimento da criatividade e de competências, como a resolução de problemas 
Da mesma forma, GREEN et al. (1980) propõem estratégias para a educação em saúde. As diferentes categorias de ação estão estruturadas segundo os objetivos definidos, as diversas fases do processo educacional e o envolvimento dos educandos. Muitas delas estão presentes em metodologias educativas participativas, utilizadas em educação popular (VIANNA,1986; IMDEC,1988; WALLERSTEIN \& SANCHEZMERKI, 1994).

É importante mencionar que cada estratégia didática tem potenciais educativos diferentes, permitindo que se acionem diferentes habilidades e atitudes, desenvolvendo as competências.

b) do algo novo e não visto da escola

\section{Quadro 5. Relatos da categoria do "algo novo e não visto na escola"}

Questões: Vocês gostam de aprender sobre Ciências? Por quê?

Vocês acham importante o trabalho do Clube? Por quê?

\begin{tabular}{|c|c|c|}
\hline SUJEITO & IDEIA-CENTRAL & EXPRESSÃO-CHAVE \\
\hline 1 & $\begin{array}{l}\text { Eu gosto porque tem coisa nova. Estudar } \\
\text { alfabetiza, ajuda a fazer uma faculdade, onde } \\
\text { se aprende tudo e ai se pode conseguir } \\
\text { emprego. }\end{array}$ & $\begin{array}{l}\text { Eu gosto porque tem coisa nova. Quando for } \\
\text { faculdade né, vão ter de tudo... o que nóis } \\
\text { nem sabe, nem lê, nem escrevê, né...tá bom } \\
\text { pra tê emprego. Quando nóis entra numa } \\
\text { oficina, né...igual ao meu pai, ele entrou numa } \\
\text { firma, não sabia lê , nem escrevê... os caras } \\
\text { perguntou e ele nem sabia lê e nem escrevê... }\end{array}$ \\
\hline 4 & $\begin{array}{l}\text { É legal, porque a gente aprende mais e na } \\
\text { escola nunca teve Ciencias. }\end{array}$ & $\begin{array}{l}\text { E legal . porque a gente aprende mais ...porque } \\
\text { na escola nunca teve Ciências. }\end{array}$ \\
\hline 7 & $\begin{array}{l}\text { Têm coisas que a gente nunca aprendeu na } \\
\text { escola e aprende aqui. }\end{array}$ & $\begin{array}{l}\text { Têm coisas que a gente nunca aprendeu na } \\
\text { escola c aprende aqui. }\end{array}$ \\
\hline
\end{tabular}


Discurso do Sujeito Coletivo:

"Wu gosto porque (no Clube) tem coisa nova e a gente aprende mais. Têm coisas que a gente nunca aprendeu na escola e aprende aqui. Na escola nunca teve Ciências."

Submetidos às mais diversas ações de ensino e aprendizagem, mediados pela educadora, as crianças foram estimuladas a atuar, discutir e registrar sobre assuntos que fazem parte do dia-a-dia e que compôem o universo da cultura científica e tecnológica. Isso permitiu que as crianças reconhecessem o clube como um locus gerador de conhecimentos. Tais ações constituíram-se em uma referência para outra entidade educativa presente na vida das crianças, a escola. Ao compará-la com o clube, os educandos perceberam a dimensão do seu trabalho na disciplina, reconhecendo sua ausência no âmbito escolar.

Mesmo fazendo parte do currículo do ensino fundamental, os conteúdos de Ciências e Saude, como indicam os depoimentos, foram raramente vistos em sala-deaula, apontando para a não-priorização destes no processo de ensino formal.

$\mathrm{Na}$ educação básica, em especial nas duas primeiras séries iniciais, muitas vezes, o ensino de conhecimentos científicos e tecnológicos ficam deslocados para um segundo plano. A prioridade são as matérias chamadas “instrucionais”: Linguagem e Matemática. Dessa forma, os conceitos de Ciências e Saúde acabam sendo tratados de maneira episódica e circunstancial, sem continuidade e/ou sistematização. FREIRE (2000) constatou que os docentes do ciclo básico reconhecem a importância dos conteúdos científicos para a formação dos alunos, mas acabam priorizando a alfabetização das letras e do cálculo, não reconhecendo que podem utilizar outras áreas do conhecimento para executar essa tarefa.

Muitos professores não priorizam tais conhecimentos para crianças pequenas. Alguns alegam que elas não têm estruturas mentais para o entedimento de assuntos tão 
complexos. Outros não estão suficientemente capacitados para o desenvolvimento de atividades que envolvem um corpo de conhecimentos tão amplo (COLL, 1994; FUMAGALLI, 1998; WEISSMANN,1998)

Devemos lembrar que a criança é bastante curiosa. Ela observa, pensa e tem esquemas explicativos sobre fenômenos da natureza. $O$ fato de não se permitir que ela busque respostas às suas indagações e teste suas idéias, alterando e/ou ampliando seu conhecimento, é uma forma de discriminá-la, deixando-a à parte dos acontecimentos do seu mundo.

FUMAGALLI (1998) afirma que o conhecimento em Ciências é um direito da criança e deixá-la no desconhecimento é desvalorizá-la como sujeito social.

c) da ampliação e aplicação do conhecimento

Quadro 6. Depoimentos da categoria "ampliação e aplicação do conhecimento".

Questões: Vocês gostam de aprender sobre Ciências? Por quê?

Vocês acham importante o trabalho do Clube? Por quê?

\begin{tabular}{|c|c|c|}
\hline SUJEITO & IDÉIA-CENTRAL & EXPRESSÃO-CHAVE \\
\hline 8 & $\begin{array}{l}\text { É legal, porque gosto de aprender sobre os } \\
\text { nutrientes, de explorar e de saber sobre o } \\
\text { corpo. }\end{array}$ & $\begin{array}{l}\text { É legal, porque eu gosto de aprender sobre os } \\
\text { nutrientes e pra explorar...pra saber sobre o } \\
\text { nosso corpo... }\end{array}$ \\
\hline 9 & $\begin{array}{l}\text { É bom, porque aprende muita coisa. Aprender } \\
\text { educa e ajuda a não ficar doente. }\end{array}$ & $\begin{array}{l}\text { É bom, porque aprende muita coisa .. pra não } \\
\text { fícar mal educado...pra não ficar doente. }\end{array}$ \\
\hline 10 & É bom, porque cuidamos da saúde. & E bom, porque cuidamos da saude. \\
\hline 11 & Faz parte da nossa vida. & $\begin{array}{l}\text { Faz parte da nossa vida } \\
\text { (Continua) }\end{array}$ \\
\hline
\end{tabular}




\begin{tabular}{|c|c|c|}
\hline & & \begin{tabular}{|l|} 
(Continuação Quadro 6) \\
\end{tabular} \\
\hline 12 & Faz parte da nossa higiene. & Faz parte da nossa higiene \\
\hline 13 & $\begin{array}{l}\text { É legal, porque aprende muitas coisas sobre } \\
\text { as plantas, o corpo e os alimentos } \\
\text { Precisamos saber sobre o corpo e os } \\
\text { alimentos. }\end{array}$ & $\begin{array}{l}\text { E legal, porque a gente aprende mais coisa } \\
\text { e das plantas, do corpo..., um monte de } \\
\text { coisas...Ah! acho que a gente tem de saber do } \\
\text { corpo ...e os alimentos... }\end{array}$ \\
\hline 14 & $\begin{array}{l}\text { Acho bom, porque a gente aprende muitas } \\
\text { coisas. (Aqui se) fala sobre o corpo e do } \\
\text { pulmão. }\end{array}$ & $\begin{array}{l}\text { Acho bom, porque a gente aprende mais... fala } \\
\text { do corpo...do pulmão, né? Acho bom ...não sei } \\
\text { porque... }\end{array}$ \\
\hline 16 & $\begin{array}{l}\text { Porque a gente aprende coisas, sobre as } \\
\text { plantas e o solo. Você tem que lembrar das } \\
\text { coisas aprendidas na escola. Quando eu for } \\
\text { professora, eu vou educar meus alunos, } \\
\text { mesmo os piores e vou me lembrar das coisas } \\
\text { que você ensinou. }\end{array}$ & $\begin{array}{l}\text {... porque a gente aprende ....sobre a plantas ... as } \\
\text { terra... No passado você tem que se lembrá das } \\
\text { coisas que aprendeu na escola...colocar na } \\
\text { cabeça um pouquinho de cada coisa. Quando } \\
\text { for professora, eu vou educá meus alunos, } \\
\text { mesmo que sejam os pior da sala...mas eu vô. } \\
\text { Aí eu vô lembrar do que você falô. }\end{array}$ \\
\hline 17 & $\begin{array}{l}\text { Porque a gente fica sabendo. Quando } \\
\text { crescermos, poderemos fazer o mesmo. }\end{array}$ & $\begin{array}{l}\text { Porque a gente fica sabendo...quando a gente } \\
\text { crescê a gente pode fazer... }\end{array}$ \\
\hline 23 & $\begin{array}{l}\text { Fala sobre a natureza, as plantas e como } \\
\text { cuidar delas. Aprende-se mais, de modo que } \\
\text { quando for adulto sc pode usar estes } \\
\text { conhecimentos para trabalhar. }\end{array}$ & $\begin{array}{l}\text { Fala sobre as plantas...a natureza...pra } \\
\text { plantá... aprendê a cuidá das plantas...vai } \\
\text { aprendendo mais...quando crescê até pode } \\
\text { trabalhar com outras pessoas sobre isso... }\end{array}$ \\
\hline 24 & $\begin{array}{l}\text { É legal, pois aprende e mexe com muitas } \\
\text { coisas e o estudo da natureza é importante. }\end{array}$ & $\begin{array}{l}\text { É legal...aprende muita coisa ...porque a gente } \\
\text { mexe com um monte de coisa...porque o } \\
\text { estudo da natureza é importante... }\end{array}$ \\
\hline 25 & $\begin{array}{l}\text { Aprendemos sobre a vida das plantas e de } \\
\text { como plantar. Podemos explicar tudo para a } \\
\text { mãe }\end{array}$ & $\begin{array}{l}\text { A gente aprende sobre a vida das plantas... a } \\
\text { gente planta...a gente explica pra } \\
\text { mãe...explica tudo...pra viver... }\end{array}$ \\
\hline
\end{tabular}




\section{Discurso do Sujeito Coletivo}

"li bom, porque aprendemos sobre a vida das plantas, de como plantar e cuidar delas, $e$ o estudo da natureza é importante. Aprendemos também a cuidar do nosso corpo e da sáude. Acho que a gente precisa saber sobre o corpo, os alimentos e a higiene, isso faz parte da nossa vida.. Aprender ajuda a não ficar doente."

O trabalho do Clube procurou estimular o estabelecimento de relações entre diferentes áreas do conhecimento. Todos os momentos eram usados para aprender, desde usar o dicionário para identificar a forma correta de escrever uma palavra, até medir com uma trena os passos de crianças, durante a definição dos canteiros da horta.

Houve uma preocupação com as interações entre diferentes fatos e objetos, enfatizando a relação causa e efeito. Para tanto foram mobilizados os conhecimentos que faziam parte da bagagem das crianças, muitos deles espontâneos, outros já parcialmente elaborados, de modo formal. Estes foram considerados e serviram como ponto de partica para o desenvolvimento e ampliação de concepções. Assim, os conhecimentos emanaram das ações e procedimentos. Vale a pena lembrar que essa forma própria de fazer Ciência não tinha como objetivo transformar as crianças em minicientistas, mas atribuir significado e funcionalidade ao que se aprende. Além disso ficou evidenciado que os conhecimentos vistos ultrapassam os limites do clube, atingindo pessoas que fazem parte da vida das crianças, como familiares.

Estudos têm mostrado que em situações de aprendizagem as crianças não estão "vazias", mas possuem esquemas de conhecimentos, nos quais estão dipostos conceitos construídos no âmbito escolar e na prática cotidiana, fora da escola. Eles são persistentes, provavelmente porque possuem coerência para os sujeitos que as sustentam, como afirma FUMAGALLI (1998). A autora considera ainda que tais esquemas se constituem em instrumentos eficazes para a previsão e explicação dos fenômenos cotidianos. 
Dentro da abordagem construtivista, o clube abriu espaço para um trabalho voltado à interação entre os conhecimentos, enriquecendo-os e tornando-os ampliados, como afirma WEISSMANN (1993), permitindo relativizar as teorias espontâneas das crianças.

d) da formação profissional, acesso à faculdade e garantia de emprego

Quadro 7. Depoimentos da categoria "formação profissional, acesso à universidade e garantia de emprego"

Questões: Vocês gostam de aprender sobre Ciências? Por quê?

Vocês acham importante o trabalho do Clube? Por quê?

\begin{tabular}{|c|c|c|}
\hline SUJEITO & IDÉIA-CENTRAL & EXPRESSÃO-CHAVE \\
\hline 1 & $\begin{array}{l}\text { Eu gosto porque tem coisa nova. Estudar } \\
\text { alfabetiza, ajuda a fazer uma faculdade, onde } \\
\text { se aprende tudo c ai se pode conseguir } \\
\text { emprego. }\end{array}$ & $\begin{array}{l}\text { Eu gosto porque tem coisa nova. Quando for } \\
\text { faculdade né, vão ter de tudo... o que nóis } \\
\text { nem sabe, nem lê, nem escrevê, né..tá bom } \\
\text { pra tê emprego. Quando nóis entra numa } \\
\text { oficina, né...igual ao meu pai, ele entrou numa } \\
\text { firma, não sabia lê , nem escrevê... os caras } \\
\text { perguntou e ele nem sabia lê e nem escrevê... }\end{array}$ \\
\hline 2 & $\begin{array}{l}\text { Estudar me ajuda a ser bom aluno e ter } \\
\text { melhor aproveitamento. (Saber) é importante } \\
\text { na entrevista para conseguir um emprego. }\end{array}$ & $\begin{array}{l}\text {...quando a gente crescê os caras vão pegar } \\
\text { nossas provas pra ver se a gente melhorou...se } \\
\text { a gente é bom..e aí é bom estudá } \\
\text {...importante pra quando eles vão perguntá } \\
\text { que número a gente sabe e o que a gente num } \\
\text { sabe. Eles pergunta romano, ninguém sabe } \\
\text { eles mandam a gente embora, aí a gente fica } \\
\text { na rua igual os outros. }\end{array}$ \\
\hline 9 & $\begin{array}{l}\text { E bom, porque aprende muta coisa Aprender } \\
\text { educa c ajuda a nào ficar doente. }\end{array}$ & $\begin{array}{l}\text { É: bom, porque aprende muita coisa ...pra não } \\
\text { (Continua) }\end{array}$ \\
\hline
\end{tabular}




\begin{tabular}{|c|c|c|}
\hline & & (Continuação-Quadro 7) \\
\hline & & ficar mal educado... pra não ficar doente. \\
\hline 16 & $\begin{array}{l}\text { Porque a gente aprende coisas, sobre as } \\
\text { plantas e o solo. Você tem que lembrar das } \\
\text { coisas aprendidas na escola. Quando cu for } \\
\text { professora, eu vou educar meus alunos, } \\
\text { mesmo os piores e vou me lembrar das coisas } \\
\text { que você ensinou. }\end{array}$ & $\begin{array}{l}\text {...porque a gente aprende . sobre a plantas ... as } \\
\text { terra... No passado você tem que se lembrá das } \\
\text { coisas que aprendeu na escola ...colocar na } \\
\text { cabeça um pouquinho de cada coisa. Quando } \\
\text { for professora, eu vou educá meus alunos, } \\
\text { mesmo que sejam os pior da sala... mas eu vô. } \\
\text { Aí eu vô lembrar do que você falô. }\end{array}$ \\
\hline 17 & $\begin{array}{l}\text { Porque a gente fica sabendo. Quando } \\
\text { crescermos, poderemos fazer o mesmo. }\end{array}$ & $\begin{array}{l}\text { Porque a gente fica sabendo...quando a gente } \\
\text { crescê a gente pode fazer... }\end{array}$ \\
\hline 18 & $\begin{array}{l}\text { Elas (a Ciências e a Saúde) são muito legais. } \\
\text { A gente aprende tudo e pode ser professora } \\
\text { de Ciências. }\end{array}$ & $\begin{array}{l}\text { Porque elas são muito legal ... a gente vai } \\
\text { aprendendo tudo ... a gente pode ser professora } \\
\text { de Ciências. }\end{array}$ \\
\hline
\end{tabular}

\section{Discurso do Sujeito Coletivo:}

"Estudar é bom para não ficar mal educado. Aprender a cuidar das plantas, pode me ajudar no futuro, pois se pode trabalhar (com isso) com outras pessoas, ser professora $e$ também entrar em uma faculdade. (Nas entrevistas) quando as pessoas fizerem perguntas e mandar ler ou escrever, senão soubermos não seremos aceitos (para o trabalho) e iremos ficar na rua igual aos outros."

A idéia representacional evidenciada nessa categoria é de âmbito claramente social e retrata uma realidade na vida das crianças, de seus familiares e amigos, a questão do desemprego. 
Ao apresentar essa modalidade de discurso, ficam evidentes as relações estabelecidas entre conhecer, acesso a um curso superior e tornar-se um profissional. Assim, as crianças entendem que aumentar o conhecimento permitiria não só o ingresso a uma faculdade, mas a construção de uma profissão, garantindo no futuro um emprego.

e) do reforço escolar

Quadro 8. Depoimentos da categoria "reforço escolar"

Questões: Vocês gostam de aprender sobre Ciências? Por quê?

Vocês acham importante o trabalho do Clube? Por quê?

\begin{tabular}{|l|l|l|}
\hline SUJEITO & \multicolumn{1}{|c|}{ IDÉLA-CENTRAL } & \multicolumn{1}{|c|}{ EXPRESSÃO-CHAVE } \\
\hline 3 & $\begin{array}{l}\text { Permite escrever sobre os conhecimentos na } \\
\text { prova. }\end{array}$ & $\begin{array}{l}\text {.porque a gente fala sobre eles } \\
\text { (conhecimentos de Ciências e Saúde) na } \\
\text { prova. }\end{array}$ \\
\hline
\end{tabular}

\section{Discurso do Sujeito Coletivo:}

"Porque a gente fala sobre eles (os conhecimentos de ciências e saúde) na prova."

Este discurso traduz uma possibilidade de ajuda fornecida pelo clube ao trabalho escolar, em especial em um momento crítico para a criança, na avaliação. Ele é um indicativo de uma interação, entre as possíveis, estabelecida entre os ensinos formal e não formal, evidenciando mais uma vez que as ações do clube não se restringiram apenas àquele espaço de educação, mas ultrapassou limites, adquirindo um caráter de reforço e possivelmente de complementação de conteúdos e habilidades ao trabalho de sala-de - aula. 


\subsection{A Diretora}

Ao entrevistar a diretora do CJ, Josely Alzemar Mateus Fernandes, a proposta era não só obter informações referentes aos objetivos, organização e população atendida pela instituição, mas, principalmente, verificar através dessa participante indireta, como o clube era visto por ela e o que as crianças mencionavam sobre ele, avaliando sua atuação. Assim, pôde-se verificar as relações estabelecidas, bem como sua repercussão nos âmbitos familiar e escolar, uma vez que a personagem era o elemento responsável pela administração e organização do CJ e mantinha contatos permanentes com as familias e as escolas das crianças.

A síntese do depoimento está apresentada a seguir.

"A instituição é mantida pela Congregação Santa Cruz, em convênio com a Prefeitura de São Paulo. A prioridade do CJ é tirar as crianças da rua, fazendo o acompanhamento escolar e familiar e fornecendo alimentação. (Aqui) é ter um lugar onde ficar quando não estão em sala de aula.

O CJ atende as crianças que vêm da favela Vila Nova Jaguaré e arredores como Lealdade, Santa Luzia e N.S. Aparecida. Tenho só duas crianças, no total de 135, que não são da favela. Aqui na instituição há vários programas conduzidos pelo CEDES, USP e voluntários tais como : o clube, acompanhamento psicopedagógico, artes cênicas, artes plásticas, aceleração para alfabetização, grupos de inglês e trabalhos com raciocínio lógico. Nós temos contatos com as escolas onde as crianças estudam e participamos de reuniões quando somos convocados.

O trabalho do clube estou achando fantástico. As crianças contam sobre os bichinhos que viram. A parte da Alimentação (tema estudado) foi muito importante. Vegetais que as crianças não comiam passaram a comer e hoje dão um pouco mais de valor. As crianças adoram o clubinho e cuidam, pois não gostam que mexam nos 
materiais e tirem as coisas do lugar. Llas cobram (a compra de) material. Tem criança que pediu para comprar um microscópio, uma lupa... Tem criança que me pediu para separar uma sala só para o clubinho, ou então para colocar uma porta.

Sei que na comunidade foi comentado sobre o seu trabalho. Os vizinhos queriam saber se a horta era comunitária, se vai vender..

Quando fui chamada na escola me perguntaram sobre o tipo de trabalho. As professoras queriam saber que trabalho de pesquisa as crianças estavam fazendo. Expliquei sobre o clube e a professora de classe falou que percebeu que as crianças que participam deste trabalho têm mais facilidade para estar distinguindo o conhecimento. Inclusive têm professoras que querem um horário para falar com você.

As creches que estão com a gente também querem fazer um trabalho parecido, pois a Sandra (monitora) o explicou na reunião. Inclusive na prefeitura já chegou, porque a Leda (assistente social da prefeitura) esteve aqui e se interessou em passar (este programa ) para outras entidades.

As crianças estão realmente gostando!"'

\subsection{A monitora}

O grupo de crianças, o qual foi designado para participar do programa, tinha como monitora a professora Sandra Maria Bezerra Cardoso. Sempre presente aos nossos encontros, ela se mostrou envolvida com o programa, acabando por desenvolver também seus experimentos e observações. Assim, no momento das discussões na roda, ela se colocava, mostrando suas idéias, não só porque as crianças cobravam, mas, sobretudo, porque para ela tratava-se de uma nova forma de aprendizado. Nas atividades ela fazia perguntas e se posicionava na fila para observar na lupa ou microcopio, como um dos 
educandos. Muitas vezes, ajudou na organização do espaço, na distribuição dos materiais, no controle da disciplina e no recolhimento dos registros. Solícita, nos outros dias da semana, ela assumia a responsabilidade de lembrar as crianças de fazer anotações e registrar os dados dos experimentos em andamento ou para a manutenção das plantas e animais, contribuindo de maneira positiva com a proposta. Seu depoimento foi recolhido e está resumido a seguir:

"Eu praticamente estou gostando. Vejo as crianças muito interessadas e constantemente elas estão falando de alguma coisa que viram com você ou que comentam em casa. Eu acho que absorvem alguma coisa, não totalmente, mas um pouco sempre entra na cabecinha deles. Na escola o trabalho de Ciências é diferente do que eles veem aqui. Aqui é uma forma mais gostosa e elas absorvem o trabalho"

\subsection{As Crianças na Escola}

Nas entrevistas efetuadas com as crianças, muitos depoimentos mostraram que o trabalho efetuado nas inúmeras sessões do clube, era comentado na escola, indicando que havia ultrapassado os limites do CJ. Algumas crianças, textualmente, mencionaram que haviam contado aos seus colegas e à professora de classe sobre as diversas atividades desenvolvidas, tais como a construção de experiências, a criação de animais, o cultivo das plantas na horta, a preparação dos painéis e a visita ao museu. Um dos meninos havia inclusive sugerido à professora que fizesse experimentos similares aos preparados no clube.

Do total de crianças, vinte e quatro delas cursavam as séries iniciais do ensino fundamental, na escola E.E. João Cruz Costa. Assim, a ida a este estabelecimento, onde estudava a maioria dos participantes, possibilitou um levantamento que nos deu informações sobre a repercussão das ações do clube, bem como do desempenho escolar, 
especificamente na disciplina Ciências e Saúde. Dessa forma, puderam-se obter outros indicativos da ação do clube.

O levantamento efetuado junto aos professores, com a aplicação dos questionários, nos forneceu informações de apenas seis (6) professores, atingindo is quatro séries do nivel $\mathbf{l}$. Os questionários devolvidos citaram quinze (15) crianças. Os dados obtidos estão organizados na tabela abaixo.

Quadro 9. Repercussões do Clube Segundo Professores do Ensino Formal

\begin{tabular}{|c|c|c|c|c|}
\hline $\begin{array}{l}\text { Resposta das } \\
\text { professoras }\end{array}$ & Desempenho geral & $\begin{array}{l}\text { Desempenho em } \\
\text { Ciências }\end{array}$ & $\begin{array}{l}\text { Comentários sobre } \\
\text { o Clube }\end{array}$ & $\begin{array}{l}\text { Outras } \\
\text { observaçōes }\end{array}$ \\
\hline $\begin{array}{l}1^{a} \text { série } \\
\text { ( } 1 \text { aluno) }\end{array}$ & $\begin{array}{l}\text { Disciplinado, } \\
\text { Participativo } \\
\text { Bom } \\
\text { relacionamento com } \\
\text { colegas }\end{array}$ & $\begin{array}{l}\text { Satisfatório. } \\
\text { Manifesta } \\
\text { habilidades para } \\
\text { observar e } \\
\text { argumentar }\end{array}$ & $\begin{array}{l}\text { Manifesta prazer em } \\
\text { comentar sobre o } \\
\text { Clube }\end{array}$ & $\begin{array}{l}\text { Aprende de forma } \\
\text { prazerosa, } \\
\text { sobressai-se nas } \\
\text { atitudes }\end{array}$ \\
\hline $\begin{array}{l}2 \text { sétie } \\
\text { (4 alunos) }\end{array}$ & $\begin{array}{l}\text { Participativos } \\
\text { Bom } \\
\text { relacionamento }\end{array}$ & Satisfatório & $\begin{array}{l}\text { Comentam } \\
\text { especialmente sobre } \\
\text { as atividades lúdicas } \\
\text { do Clube }\end{array}$ & \\
\hline $\begin{array}{l}3^{\mathrm{a}} \text { série } \\
\text { (2 alunos) }\end{array}$ & $\begin{array}{l}\text { Membros do Clube } \\
\text { são mais } \\
\text { participativos }\end{array}$ & $\begin{array}{l}\text { Enriquecem as } \\
\text { discussões, } \\
\text { provocam } \\
\text { curiosidade nos } \\
\text { outros alunos }\end{array}$ & $\begin{array}{l}\text { Comentam } \\
\text { especialmente sobre } \\
\text { atividades lúdicas } \\
\text { do Clube }\end{array}$ & $\begin{array}{l}\text { Interagem mais na } \\
\text { área de Ciências e } \\
\text { Saúde }\end{array}$ \\
\hline $\begin{array}{l}4 \text { série } \\
\text { (6 alunos) }\end{array}$ & $\begin{array}{l}\text { Participativos, bom } \\
\text { desempenho e boa } \\
\text { socialização }\end{array}$ & Bom a satisfatório & $\begin{array}{l}\text { Sim quando se trata } \\
\text { de assuntos } \\
\text { abordados no Clube }\end{array}$ & $\begin{array}{l}\text { Maior interação na } \\
\text { area de Ciências e } \\
\text { Saúde }\end{array}$ \\
\hline
\end{tabular}


Embora não se possa afirmar que o desempenho escolar apresentado pelas crianças tenha sido resultado direto da ação educativa do clube, os dados nos sugerem alguns aspectos da atuação das mesmas em sala-de-aula.

Todos os professores foram unânimes em afirmar que as crianças eram participativas, mostrando-se bastante ativas nos trabalhos escolares e tendo um desempenho satisfatório. Evidencia-se que, ao participarem, as crianças apresentaram os conhecimentos aprendidos no âmbito do clube "ilustrando"e enriquecendo o trabalho da professora, por ocasião de sua exposição sobre temas correlatos. Outro aspecto apontado foi o bom relacionamento das crianças do clube com seus colegas, ensinandolhes sobre assuntos vistos nos trabalhos do clube, confirmando os dados obtidos nos depoimentos das crianças e diretora.

Chamaram especial atenção as informações colocadas por duas professoras, uma da $1^{\text {a }}$ e outra da $3^{\mathrm{a}}$ séries, cujos alunos apresentaram habilidades reconhecidas $\mathrm{e}$ identificadas por elas de tal forma que os alunos da $3^{a}$ série apresentaram habilidade em nivel mais complexo, identificada como capacidade de abstração.

Os levantamentos efetuados junto à diretora, monitora e professores de classe, sobre a atuação educativa do clube forneceram-nos dados que mostram o sucesso da proposta, manifestado através da aquisição de conhecimentos e habilidades em situações dinâmicas de aprendizagem.

\section{O Clube de Ciências e Cultura e a Promoção em Saúde}

A educação tem sido aclamada como área-chave para enfrentar os novos desafios e as transformações do mundo atual. Ao lado de outras ações, ao promover o acesso aos conhecimentos, ela permite a inserção da parcela excluída na sociedade. Como enfatizado neste trabalho, a educação não se retringe a processos formais de 
ensino e aprendizagem, mas pode se fazer presente também sob uma dimensão nãoformal, em espaços da sociedade civil e comunitária. Clubes de Ciências e Cultura se inserem nessa dimensão e constituem um modelo possivel de ação educativa, desde que aplicado de forma organizada e permanente, explicitando propostas e programas, especialmente aqueles voltados para a promoção em saúde.

As ações pertinentes a programas especialmente preparados devem estruturar atividades que possibilitem conteúdos específicos de eleição. A promoção de habilidades, ao lado de conceitos específicos, abrange o desenvolvimento das competências, atitudes e valores, os quais devem estar no centro da aprendizagem, promovendo a qualificação do educando e fortalecendo-o para a vida atual.

Neste contexto é importante mencionar o artigo de DIMENSTEIN "Por que o diploma é uma bobagem" (Folha de S. Paulo, 1999), onde o autor afirma que o culto ao diploma apresentado pela sociedade atual se torna inútil quando os graduados são entrevistados em processos de seleção pelas grandes empresas. Cada vez menos são pedidos os conhecimentos técnicos e mais capacidade de inovação, criatividade e trabalho em grupo, mostrando que a escola que se conhece hoje não prepara, ou prepara muito mal os seus jovens. Ainda nessa linha, MENEZES (2000) enfatiza o papel não desempenhado pela escola na preparação de profissionais competentes para o mercado de trabalho, que, por sua vez, está se tornando cada vez mais exigente, a ponto dele considerar ser esse o desafio do milênio.

LEFÈVRE (1999), por outro lado, ao tratar da promoção em saúde, aponta que para o fortalecimento dos indivíduos e da coletividade é necessária uma pedagogia não normativa e sim mais dialógica, na vertente freireana, com oportunidades de propiciar encontros e trocas, buscando diminuir as limitações impostas pelas defasagens de escolaridade e de conhecimento entre o informador e os informados. 
Idealmente, a proposta educativa deve visar a formação integral do ser humano nas diversas dimensões: física, afetiva e cognitiva. Para tanto, é preciso traduzir estes aspectos em práticas concretas, investindo democraticamente no desenvolvimento das capacidades cognitivas e operatórias para se chegar ao pensamento autônomo, crítico e criativo e assim sobreviver em um mundo tão complexo como o atual (LIBÂNEO, 2001)

Quanto à seleção da comunidade alvo de nosso estudo, centrado em uma comunidade carente, é oportuna a matéria publicada por VASCONCELOS (Folha de São Paulo, 2001), a qual apresenta o "mapa da exclusão", e avalia, sob uma perspectiva inédita, a possibilidade de lazer e cultura para os jovens. A matéria relata uma pesquisa encomendada pela Organização Mundial da Saúde, e declara que embora o consumo de drogas esteja disseminado em todas as classes sociais, os jovens da periferia são mais suscetiveis de se tomarem dependentes ou vinculados ao tráfico, pois suas motivações e consequências são diferentes das existentes para jovens de áreas ricas. Os jovens da periferia não têm lazer e cultura. É urgente a necessidade de construção de espaços para o desenvolvimento de atividades que forneçam opções de lazer e cultura, os quais devem ser incrementados e multiplicados como forma de ocupar o tempo livre das crianças e adolescentes.

Setores fundamentais, como o da saúde, vêm buscando novas estratégias metodológicas e de conteúdo, envolvendo novas áreas dentro de uma abordagem holística de sáude como resposta aos desafios das grandes metrópoles. Neste sentido, na pespectiva da promoção da saúde, a educação aparece como uma das referências e instrumento democrático, podendo atuar como mobilizadora e supridora de mecanismos de inclusão social e constituindo-se como via de acesso à cidadania e fortalecimento dos indivíduos (SANTOS e WESTPHAL, 1999).

Entre os novos modelos ou paradigmas que buscam melhorar a qualidade de vida destacamos o programa Municípios/Cidades Saudáveis Sob essa perspectiva a cidade é 
vista como espaço de intervenção e mobilização em tomo de projetos comuns e de interesse coletivo, que respondam às necessidades sociais, de solidariedade $e$ cooperação, e à integração de políticas públicas. A referida proposta está alicerçada nos pressupostos: saúde como qualidade de vida; participação popular e democracia; valorização do compromisso político com eqüidade, e mudanças na gestão dos diferentes níveis do governo local. Sob essa visão, não só a saúde, mas principalmente a educação, entre outros setores, devem estar envolvidos, o que confere à proposta um caráter altamente transdisciplinar (SANTOS e WESTPHAL, 1999). É, talvez, por isso, que os referidos autores conclamam a união de universidades, escolas de saúde, associações e conselhos comunitários, no enfrentamento dos desafios para a implantação do movimento por cidades saudáveis, como um novo paradigma para o milênio que se inicia. 

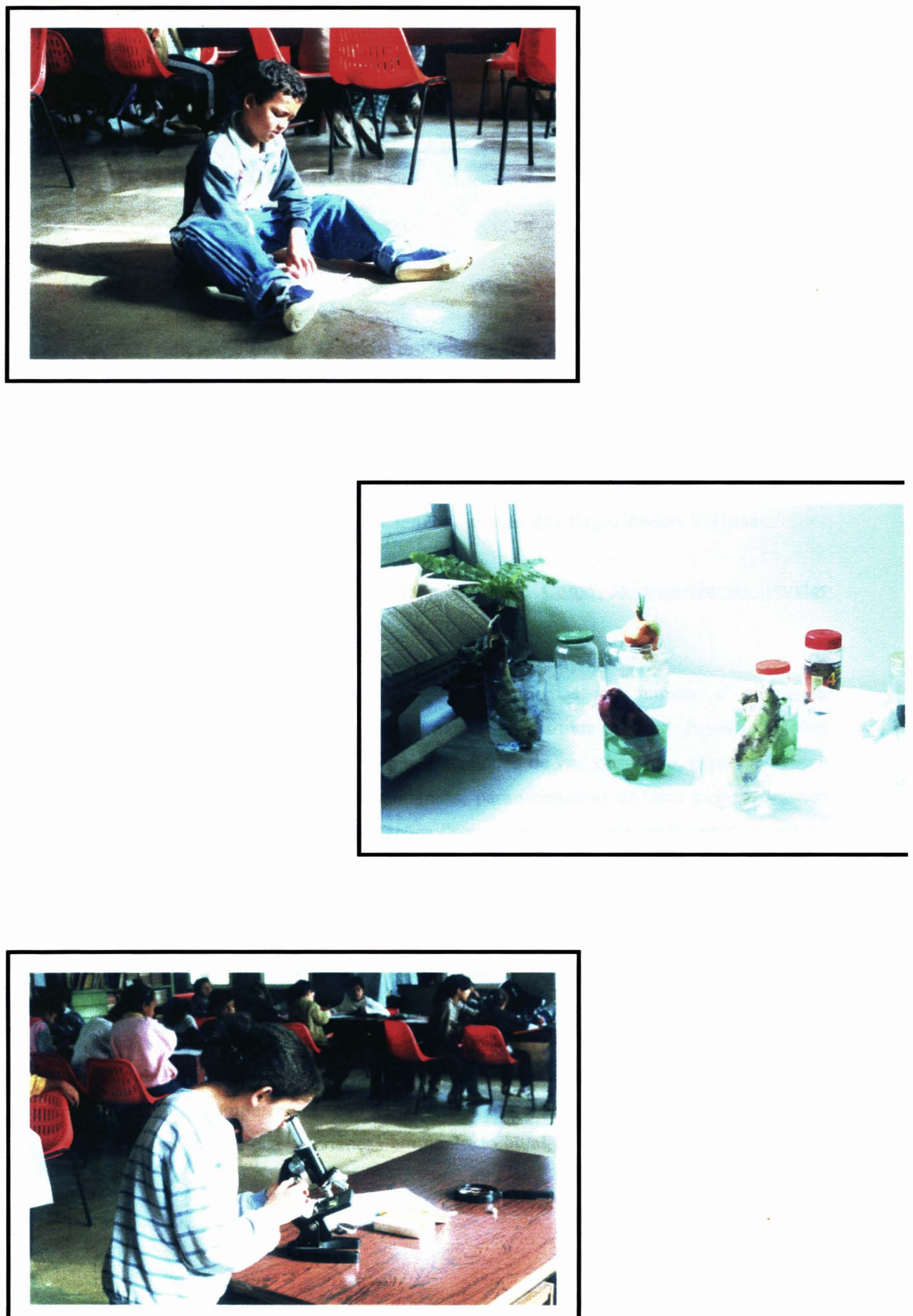


\section{IV - CONSIDERAÇÕES FINAIS}

\section{Reflexões}

Da reflexão e análise de todo o processo, objeto deste trabalho, e com o propósito de ordenar as idéias centrais que o nortearam, sobressaem duas dimensões do processo educativo proposto pela ação do Clube, que devem ser consideradas antes das conclusões

\section{Conhecendo e (Re) Construindo a Ciência Através das Experiências Vividas}

Nesta dimensão podemos colocar a questão: Como as experiências vividas aproximaram as crianças da Ciência?

Crianças, como jovens e adultos, estão imersos no mundo e interagem cotidianamente em diferentes realidades: natural, construída e social. Essas interações geram conhecimentos. As crianças, com seus modos de ver, observam, experimentam e conhecem criando suas "teorias" espontâneas, para interpretar os fatos e os fenômenos ao seu redor. Muitas de suas explicações "resolvem" seus questionamentos, enquanto que outros permanecem sem repostas. De qualquer forma, suas múltiplas leituras, embora supram sua compreensão de mundo, deixam-nas à margem da Ciência, pois são ingenuamente construídas a partir da vivência. Não que ela não seja importante, mas resultam em conhecimento superficial e com qualidade menor.

Não há dúvida sobre a importância e valor do conhecimento científico. A possibilidade de atuar de maneira ativa, experimentando no mundo da Ciência e desenvolvendo competências, não só permite a apropriação de novos conhecimentos e significados, mas coloca as crianças em contexto atual, instrumentalizando-as para que 
se tornem mais conscientes e adquiram senso critico, fortalecendo sua participação no grupo social em que estão inseridas

Neste sentido, endossamos a citação de VÁSQUEZ (1984), apresentada por FUMAGALLI (1998, p. 17),

As crianças exigem o conhecimento das ciências naturais porque vivem num mundo no qual ocorre uma enorme quantidade de fenômenos naturais para os quais a própria criança deseja encontrar uma explicação; um meio no qual todos estamos cercados de uma infinidade de produtos da ciência e da tecnologia que a própria criança usa diariamente e sobre os quais se fazem inimeras perguntas; um mundo no qual os meios de informação social a bombardeiam com noticias e conhecimentos, alguns do quais não são realmente cientificos, sendo a maioria supostamente cientificos, mas de qualquer forma contendo dados e problemas que amiide a preocupam e angustiam.

É preciso ressaltar que a proposta do clube não era transformar as crianças em pequenos cientistas, pois a ciência do cientista e a ciência aprendida no âmbito educativo se propõem a objetivos diferentes. Era permitir que elas se aproximassem do fazer do cientista, usando a capacidade criativa e espírito crítico, para a busca de soluções de problemas reais, em um trabalho cooperativo e de trocas.

Nesta circunstância, o trabalho com a horta envolvendo assuntos como: o homem e seus alimentos, a nutrição, a germinação de sementes, o cultivo de plantas, os animais que são pragas, a água, os tipos de solo e as inter-relações que estabelecem estes componentes, e a participação das crianças com suas observações, discussões e levantamento de hipóteses, organização de experimentos, manipulação de materiais e instrumentos, interpretação e registro de dados, permitiu que as crianças vivenciassem situações diferenciadas, gerando conhecimentos.

Assim, a ciência emergiu das experiências vividas e compartilhadas 


\section{Conhecendo e (Re) Construindo as Experiências Vividas Através da Ciência}

A questão que se propõe nesta dimensão é Como o conhecimento cientifico interfere nas experiências vividas?

Sob esta ótica, é preciso avaliar a idéia sobre a importância de propiciar às crianças significados às experiências vividas, a partir da aquisição de conhecimentos da Ciência.

Ao se apropriar de conhecimentos construídos a partir de ações educativas estruturadas, um novo olhar manifesta-se. As relações reflexivas entre o conhecimento científico e as experiências vividas apresentam e conectam novas idéias e interpretações, atribuindo novos significados ao observado. Assim, o conhecimento científico emanado daquelas ações altera a forma como as crianças entendem e executam suas experiências. Suas subjetividades dão forma às questões, impulsionando-as e desafiando-as a observar sob nova perspectiva, em um processo de retroalimentação. A Ciência foi "usada" para entender sua própria vida.

Nessa dimensão, a presença de um professor/educador é vital nas representações e manifestações de identidades das crianças com a Ciência. O professor é o condutor e articulador do processo pedagógico, estimulando e ajudando-as a refletirem sobre as experiências vividas, relacionando-as com a Ciência. COSTA (1999) ressalta que a ação concientizadora do educador reside na sua contribuição para que o educando construa uma representação de si e do seu mundo.

A Ciência deve ser vista e entendida não como um conjunto de verdades que devem ser memorizadas, mas para propiciar funcionalidade ao que se aprende. WEISSMANN (1998) aponta, com propriedade, que a prática docente, bem como parte dos textos escolares tomam trivial a ciência dos cientistas, colocando o conhecimento como um conjunto de verdades fechadas, anônimas e a-históricas; mas, o que é importante é a criança reconhecer que os conceitos ou teorias propostos pelos cientistas são resultados 
de problemas reais, que foram solucionados, segundo o momento histórico a que pertenciam, com criatividade, através de caminhos construídos e percorridos usando a observação, a interpretação e a descoberta

\section{Repercussões do Clube}

Ao procurar eventuais repercussões do processo desenvolvido, encontramos evidências do envolvimento e empenho com que as crianças participaram dos trabalhos, explicitados por suas atitudes e práticas, e refletidas na forma e qualidade de atuação, assim como nas relações interpessoais estabelecidas, com resultados visíveis em seu registros. Tudo isto, somado aos depoimentos concedidos pelos próprios educandos, diretora e monitora, acrescido das informações fornecidas pelas professoras do ensino formal, mostrou impactos positivos que apontam para o sucesso do programa. Além desses indicadores de sucesso, destacamos o desenvolvimento de várias habilidades e conhecimentos pertinentes à educação e à cultura científica, dentro da promoção da saúde.

A avaliação não é um fím em si mesma, mas parte do processo, permitindo determinar, entre outros aspectos, o valor e as limitações do programa aplicado. BENNETT (1988) afirma não haver prioridade para a definição de graus e valores, no processo de avaliação, como pensam, inclusive, muitos professores ao avaliarem as conquistas de seus alunos. O referido autor afirma que os produtos e o processo, incluindo planejamento, aplicação e aprendizagem, além das condições ou contextos intrínsicos à sua realização, são alguns critérios para avaliar. Ele sugere uma série de instrumentos tais como testes, questionários, entrevistas, observação direta e produção de artefatos, muitos dos quais, conforme vimos, foram aplicados em nosso trabalho.

Foi completamente descartada a aplicação de testes com questões sobre os conteúdos junto às crianças. Isto devido à própria proposta educativa do programa como, também, pelo fato das crianças trabalharem em grupo, em mesas coletivas, possibilitando 
copiarem as respostas umas das outras, interferindo, portanto, na validade dos resultados

Finalmente, é preciso mencionar, que os resultados da avaliação possibilitam a tomada de medidas que levem ao aprimoramento do programa como um todu, permitindo correções de rumo para tornar ainda mais eficazes os objetivos traçados $a$ priori, tendo em vista sua eventual continuidade e/ou aplicação.

\section{Conclusões}

Este projeto permitiu a demonstração empirica da natureza e qualidade das ações educativas de um Clube de Ciências e Cultura, voltado para crianças provenientes de uma favela e estruturado em um Centro da Juventude, como veículo e estratégia para a Promoção e Educação em Saúde. A partir dele podemos afirmar que:

- O clube se mostrou adequado como modelo, podendo ser aplicado para ampliar a relevância e efetividade das intervenções educacionais e ajudar nos programas de saúde. Sua estratégia consistiu em convocar os educandos à ação na busca de respostas e compreensão de problemas passíveis de abordagem científica, sejam individuais ou comunitários, ajudando a entendê-los e superá-los. Assim, está, portanto, perfeitamente adequado aos programas de ensino em centros comunitários, atendendo demandas e interesses de aprendizagem.

- A interação entre os ensinos formal e não-formal ficou evidenciada, pois o trabalho educativo desenvolvido mostrou ser eficiente e capaz de extrapolar o espaço do clube, com reflexos positivos no ensino escolar. 
- Quanto à estruturação, nossa prática mostrou a necessidade de um educador capacitado para a condução do trabalho, o qual deve ser responsável pela organização dos conteúdos e aplicação das sessões, estabelecendo vínculos de compromisso com as crianças e o programa

- Em relação ao planejamento ficou patente a necessidade de organizar situações de aprendizagem que permitam a construção e apropriação de conhecimentos, como forma de dar significado ao que se aprende e interiorizar os conceitos, uma vez que a proposta envolve o processo de ensino, com objetivos, conteúdos e métodos, tendo a criança como centro do processo. A estratégia enfatiza a aprendizagem com e a partir da criança, respeitande seu ritmo, e não sobre a criança.

- As expectativas e interesses dos participantes envolvidos, representados pelas crianças, diretora, monitora e professores da escola, indicam o reconhecimento dos beneficios do programa devido ao seu potencial educativo, abrindo espaço para que as crianças testem e verifiquem seus conhecimentos e interesses à luz de conceitos elaborados, resultando em novas percepções e maneiras de ver e interpretando o mundo onde vivem.

- O modelo utilizado pode ser estendido a outras situações educativas similares, com evidentes beneficios na aquisição de conhecimentos de Ciências e Saúde, bastando para isto adaptá-lo às situações específicas. 
Dome Edilron pelarmino ale Leirciza café
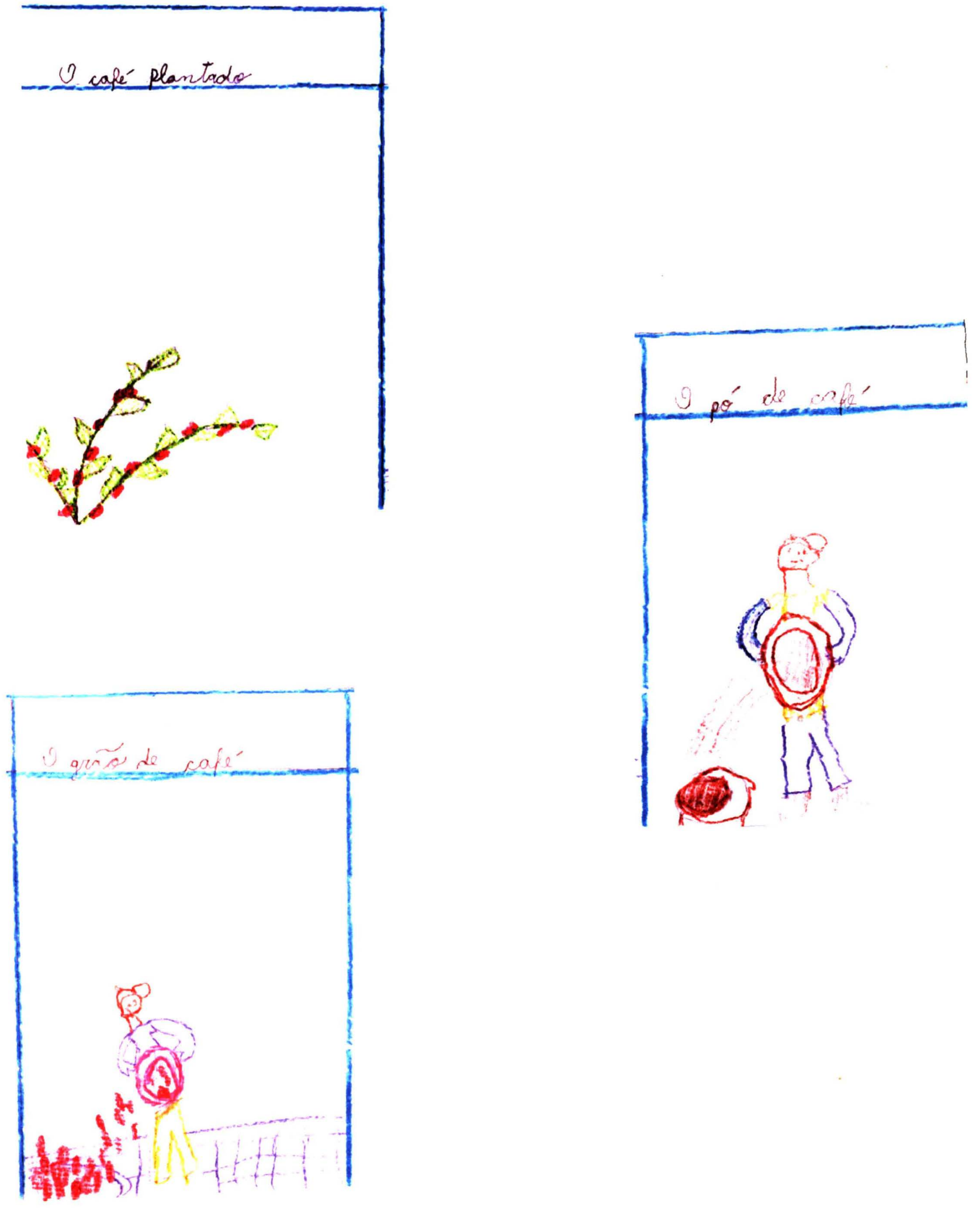


\section{V-REFERÊNCIAS BIBLIOGRÁFICAS}

Abreu Júnior L. O Conhecimento transdisciplinar: o cenário epistemológico da complexidade. São Paulo: UNIMEP; 1996.

Alves-Mazzotti AJ, Gewandsznajder F. O método nas ciências naturais e sociais: pesquisa quantitativa e qualitativa. $2^{a}$ ed. São Paulo: Pioneira; 1999

André MEDA. A pesquisa no cotidiano escolar. In: Fazenda I, organizadora. Metodologia da pesquisa educacional. São Paulo: Cortez; 1997. p. 35-45.

Augoyard P, Renaud L. Le concept d'empowerment et son application dans quelques programmes de promotion de la santé. Promot Educ 1998; 5: 28-35.

Barthes AM, Van der Vynckt S. Health, science and technology education in healthy promoting schools. Connect 1998; $23(2): 1-4$.

Barton AC. Teaching science with homeless children: pedagogy, representation, and identity. J Res Sci Teach 1998; 35: 379-94

Beard BM. Como a criança pensa: a psicologia de Piaget e suas aplicações educacionais. São Paulo: IBRASA; 1978.

Benllocch M. Por un aprendizaje constructivista de las ciências. Madrid: Visor Libros; 1984.

Bennett DB. Fourr steps do evaluating environmental education learning experiences. J Environ Educ; 1989; 20 (2): 14-21 
Bloom B, organizador. Taxionomia dos objetivos educacionais. $8^{\mathrm{a}}$ ed. Porto Alegre: Globo; 1983. 2v.

Candeias NMF. Evaluating the quality of health education programmes. Some comments on methods and implementation. Hygie 1991/ 1992; 10:40-4.

Candeias NMF. Conceitos de educação e de promoção em saúde: mudanças individuais e mudanças organizacionais. Rev Saúde Pública 1997; 31 : 209-13

Campos MCSS. Educação: agentes formais e informais. São Paulo: EPU; 1985.

Carvalho AMP, Vannucchi AI, Barros MA, Gonçalves MER, Rey RC. Ciências no ensino fundamental: o conhecimento físico. São Paulo: Scipione; 1998.

Cavalcanti $Z$. Conhecimento de adultos, saberes de crianças: trabalhando com História e Ciências na pré-escola. Porto Alegre: Artes Médicas; 1995.

Cerqueira MT. Promoción de la salud: evolución y nuevos rumbos. Bol Oficina Sanit Panam 1996; 120: 242-347.

Coll CS. Aprendizagem escolar e construção do conhecimento. Porto Alegre: Artes Médicas; 1994

Costa A. Aspectos sócio-políticos das atividades de um Clube de Ciências. In: Anais do $1^{\circ}$ forum estadual de debates sobre clubes de ciências; 1995; Porto Alegre (RS). Sec. da Educą̧ão do RG do Sul, Porto Alegre: Depto Pedagógico/ Centro de Ciências. p. 637 .

Costa ACG. A presença da pedagogia: teoria e prática da ação socioeducativa. São Paulo: Global/Inst. Ayrton Senna; 1999 
Dhillon HS, Philip L. Health in education for all: enabling school-age children and adults for health living. Hygie 1992/ 1993; 11:17-27.

Dias MTS. O Clube de Ciências como estratégia de melhoria do ensino. In: Anais do $\mathbf{1}^{0}$ forum estadual de debates sobre clubes de ciências; 1995; Porto Alegre (RS). Sec de Educação do R.G. do Sul, Porto Alegre. Depto Pedagógico/Centro de Ciências. p. 25-7

Dimenstein G. Por que o diploma é uma bobagem. Folha de São Paulo, São Paulo, $1999 \mathrm{dez} 12 ; \operatorname{cad} 3: 16$

Fazenda I. Metodologia da pesquisa educacional. $4^{\text {a }}$ ed. São Paulo: Cortez; 1997.

Ferreira $\mathrm{ABH}$. Novo dicionário da língua portuguesa. Rio de Janeiro: Nova Fronteira; 1986.

Focesi E. Uma visão de saúde escolar e educação eñ saúde na escola. Rev Bras Saúde Escolar 1992; 2: 19-21

Focesi E. Saúde escolar: promoção e educação em saúde. Conferência realizada no $3^{\circ}$ Congresso Médico, Campinas, Agosto de 1993. (Apostila).

Fracalanza H, Amaral IA, Gouveia MSF. O ensino de ciências no primeiro grau. São Paulo: Atual; 1986. (Projeto Magistério).

Freire M. A paixão de conhecer o mundo: relatos de uma professora. São Paulo: Paz e Terra; 1983

Freire P. Concientización. Buenos Aires: Ediciones Búsqueda; 1974. 
Freire P. Pedagogia da autonomia: saberes necessários à prática educativa. São Paulo: Paz e Terra; 1996.

Freire P. A pedagogia do oprimido $23^{\text {a }}$ ed. S.Paulo: Paz e Terra; 1996

Freire CY. Ensino de Ciências: o que pensam os professores polivalentes. São Paulo, Universidade de São Paulo, Faculdade de Educação, 2000. (Dissertação de Mestrado).

Frota-Pessoa O. Princípios básicos para la enseñanza de la biologia. Washington (DC): Monografia no 4. Departamento de Assuntos Científicos de la Secretaria General de la OEA; 1976. (Série Biologia; Monografia, 4).

Fumagalli L. O ensino de ciências naturais no nivel fundamental da educação formal: Argumentos a seu favor. In: Weissmann $\mathrm{H}$, organizador. Didática das ciências naturais. Porto Alegre: Artmed; 1998. p. 13-29.

Gil AC. Métodos e técnicas de pesquisa social. São Paulo: Atlas; 1994.

Gil AC. Como elaborar projetos de pesquisa. São Paulo: Atlas; 1996

Gomes CMB. Aspectos sócio-políticos das atividades de um Clube de Ciências. In: Anais do $1^{\circ}$ forum estadual de debates sobre clubes de ciências; Porto Alegre (RS). Sec de Educação do R.G.do Sul, Porto Alegre : Depto Pedagógico/ Centro de Ciências. p. 69-73.

Gomes R. A análise de dados em pesquisa qualitativa. In: Minayo MCS, organizadora. Pesquisa social: teoria, método e criatividade. $16^{\mathrm{a}}$ ed. Petrópolis: Vozes; 2000. P. 6780 . 
Hawes H. Child-to-child: another path to learning. Hamburg: Unesco Institute for Education ; 1988. (UIE Monographs, 13).

Hernadéz F, Ventura M. A organização do currículo por projetos de trabalho: o conhecimento é um caleidoscópio. São Paulo: Artmed; 1998

Hernadéz F. Transgressão e mudança na educação. Porto Alegre: Artmed; 1998.

Herrera S, Thier HD. Science for kindergarten. Berkeley: SCIS; 1974.

Hoppe MJ, Wells EA, Morrison DM, Gillmore MR, Wilsdon A. Using focus groups to discuss sensitive topics with children. Eval Ver 1995; 19: 102-114.

Hurtado CN. Educar para transformar-transformar para educar. $2^{\mathbf{a}}$ ed. Petrópolis: Vozes; 1993.

Instituto Mexicano para el Dessarrollo Comunitario (IMEDC). Técnicas participativas para la educación popular. México (DF); 1988.v.2.

Kamii C, Devries R. O conhecimento físico na educação pré-escolar: implicações da teoria de Piaget. Porto Alegre: Artes Médicas; 1986.

Katsha S, Watts SJ. School-based summer clubs. Promot Educ 1994; 1 : 24-8.

Kickbusch I. Think health: what makes the difference. In: 4th International Conference on Health Promotion; 1997; Jakarta, Malasya.

Kickbusch I, Jones T, O’Byrne D. Health-Promoting Schools. Connect 1998; 23(2): 14. 
Kolbe LJ. What can we expect from school health education?. J School Health 1982; 52: 145-50.

Krasilchik M. Prática de ensino de biologia. São Paulo: Harbra; 1986

Krasilchik M. O professor e o currículo de ciências. São Paulo: EPU/EDUSP; 1987.

Krasilchik M. Pesquisa e ensino de Biologia. In : $4^{\circ}$ Encontro-Perspectivas do Ensino de Biologia; 19 a 21 de Fevereiro, São Paulo: Faculdade de Educação USP; 1991: 1-4. (Coletânea da FEUSP).

Laville C, Dione J. A construção do saber: manual de metodologia da pesquisa em ciências humanas. Porto Alegre: Ed. UFMG/Artmed; 1999.

Lefèvre F. Promoção de saúde, informação e tomada de decisão. São Paulo: FSP/USP; 1998. (Apostila)

Lefèvre F. Educação, promoção e tomada de decisão. Jornal da USP, São Paulo, 1999 out; no 492 ; p. 2.

Lefèvre F, Lefèvre AMC, Teixeira, JJV. O discurso do sujeito coletivo: uma nova abordagem metodológica em pesquisa qualitativa. Caxias do Sul, RS: Educs RS; 2000.

Libâneo JC. Didática. $13^{\text {a }}$ ed. São Paulo: Cortez; 1994.

Libâneo JC. Adeus professor, adeus professora? Novas exigências educacionais e profissão docente. $5^{\mathrm{a}}$ ed. São Paulo: Cortez; 2001. 
Lima PC. A nova interface universidade-sociedade. Folha de São Paulo, São Paulo, 2000 nov 15; cad 1:2

Loureiro CFB. A problemática de saúde da criança no Brasil: desafios para uma prática educativa. Rev Bras Saúde Esc 1996; 4 (1/2): 17-21

Lucini FG. Temas transversales y educación en valores. Madrid: Grupo Anaya; 1994.

Lüdke M, André MEDA. Pesquisa em educação: abordagens qualitativas. São Paulo: EPU; 1986. (Temas Básicos de Educação e Ensino).

Luna SV. O falso conflito entre tendências metodológicas. In: Fazenda I, organizadora. Metodologia da pesquisa educacional. $4^{\text {a }}$ ed. São Paulo: Cortez; 1997. p. 23-33.

Maarshalk J. Scientific literacy and informal science teaching. J Res Sci Teach 1988; 25: $133-46$.

Maiocchi AND. Actividades de clubes de Ciencias en paises del cono sur. In: Anais do $1^{\circ}$ forum estadual de debates sobre clubes de ciências; 1995; Porto Alegre (RS); Sec da Educação RG do Sul, Porto Alegre: Depto Pedagógico/ Centro de Ciências, p.45-53.

Marques H. Aspectos sócio-políticos das atividades de um Clube de Ciências. In Anais do $1^{\circ}$ forum estadual de debates sobre clubes de ciências; 1995; Porto Alegre (RS); Sec. da Educação do RG do Sul, Porto Alegre: Depto Pedagógico/ Centro de Ciências, p. $57-62$.

Menezes LC. Ensinar ciências no próximo século. In: Desafios de ensinar Ciências no século 21. Hamburger EW, Matos C, organizadores. São Paulo: EDUSP; 2000. p. 4854 
Menezes LC. Conhecimento e competências no ensino médio. Tribuna do Norte, RGN, 2000 agosto $5 ;$ cad $1: 6$

Meredith JE, Fortner RW, Mullins GN. Mode of affective learning for non-formal science education facilities. J Res Sci Educ Teach 1997; 34: 805-18.

Minayo MCS. O desafio do conhecimento : pesquisa qualitativa em saúde. $4^{\mathrm{a}}$ ed., São Paulo: Hucitec-Abrasco; 1996.

Minayo MCS. Ciência, Técnica e Arte: O desafio da pesquisa social. In: Minayo MCS, organizadora. Pesquisa social: teoria, método e criatividade. $16^{\mathrm{a}}$ ed. Petrópolis: Vozes; 2000.p.9-29.

Ministério da Saúde. Promoção da Saúde: Carta de Ottawa, Declaração de Adelaide, Sundsvall e Santa Fé de Bogotá. Brasília (DF); 1996. (Apostila)

Ministério da Educação e Cultura (MEC). Parâmetros Curriculares Nacionais: ciências naturais. Brasília (DF); 1997 a. v.4.

Ministério da Educação e Cultura (MEC). Parâmetros Curriculares Nacionais: apresentação dos temas transversais e ética. Brasília (DF); 1997 b. v. 8.

Ministério da Educação e cultura (MEC). Parâmetros Curriculares Nacionais: meio ambiente e saúde. Brasília (DF); 1997 c. v. 9.

Mizukami MGN. Ensino: as abordagens do processo. São Paulo: EPU; 1986.

Moyano MF. La educación en plobación y la educatión sexual en America Latina. In: UNESCO. Proyecto Principal de Educación en America Latina y el Caribe. Santiago, Chile; 1997. (Boletim, 43) 
Nakajima H. Comprehensive school health education: suggested guidelines form action. Hygie 1992/1993; 11:7-16

Organización Panamericana de la Salud/ Organización Mundial de la Salud (OPAS/OMS). Educación para la salud en la comunidad: experiencias latinoamericanas. HSP/SILOS-38; 1996

Organização Mundial da Saúde. Glossário da saúde. Genebra: OMS; 1998. (Apostila).

Organización Panamericana de la Salud (OPAS). Escuelas promotoras a salud: entornos saludables y mejor para las generaciones futuras. Washington (DC); 1998. (Comunicación para la Salud, 13).

Pilon AF. Desarrollo de la educación en salud-una actualización de conceptos. Rev Saúde Pública 1986; 20: $391-6$.

Pridmore P. Visualizing health: exploring percepcion of children using the draw-andwrite method. Promot Educ 1996; 3: 11-5.

Ranaweera AM. Non-conventional approches to education at the primary level. Hamburg: Unesco Institute for Education; 1989. (UIE Monographs, 14).

Raths L e col. Ensinar a pensar. São Paulo: EPU, 1977

Reyzábal MV, Sanz AS. Los ejes transversales. Aprendizages para la vida. Madrid: Editorial Escuela Española; 1995.

Reis J Atividades extra-escolares da América do Sul. Bol IBECC 1973; 2: 5-7. 
Ribeiro PRC., Morales, LL, Rosa ALG. Como implantar um clube de ciências em sua escola. In: Anais do $\mathbf{1}^{\circ}$ forum estadual de debates sobre clubes de ciências 1995; Porto Alegre (RS). Sec. de Educação do RG do Sul, Porto Alegre: Depto Pedagógico Centro de Ciências. p. 83-4.

Robertson A, Minkler M. New health promotion movement: a critical examination. Health Educ Q 1994; $21: 295-312$

Santos Filho JC. Pesquisa quantitativa versus pesquisa qualitativa: o desafio paradigmático. In: Santos Filho JC, Gamboa SS, organizadores. Pesquisa educacional: quantidade-qualidade. São Paulo: Cortez; 1997. p. 13-59.

Santos JLF e Westphal MF. Práticas emergentes de um novo paradigma de saúde: o papel da universidade. In Estudos Avançados: dossiê Saúde Pública. Universidade de São Paulo, v. 13 (35); 1999. p.71-88

Saviani D. O ensino público e algumas falas sobre a universidade. $3^{\mathrm{a}}$ ed. São Paulo: Cortez/Autores Associados; 1986.

Saviani D. Escola e democracia. São Paulo: Cortez; 1989. (Coleção Polêmicas do Nosso Tempo).

SECAB/UNESCO. Manual para el fomento de las atividades científicas y tecnológicas juveniles. Bogotá (DF); 1985. (Série Ciencia y Tecnologia).

Signorelli VI. Ciências ...crianças...escola. In: Trino. $2^{\text {a }}$ ed. Escola da Vila no 1. S. Paulo: Ed. Parma; s.d.: 28-38 
Solé $\mathrm{I}$, Coll $\mathrm{C}$. Os professores e a concepção construtivista. In $\mathbf{O}$ construtivis mo na sala de aula. $5^{\text {a }}$ ed. São Paulo: Ática; 1998. p.9-28.

Sousa ICF. Reviewing research trends in health education and health promotion for children: The need to address issues related to social class, cultural background, policies and research methods. Ciênc Cult 2000; 52 (3): 154-60

Stotz EN. Enfoques sobre educação e saúde. In: Participação popular, educação e saúde: teoria e prática. Valla VV, Stotz EN, organizadores. Rio de Janeiro:Lume Dumará; 1993. P. 13-22.

Tamir P. Factors associated with the relationship between formal, informal and nonformal science learning. J Environ Educ 1990/1991; 22: 34-42.

Thiollent M. Metodologia da pesquisa-ação. $6^{\mathbf{a}}$ ed. São Paulo: Cortez; 1994.

Torres RR, Aburto CB, Arias JM. Aventuras científicas juveniles: educación extraescolar. Santiago, Chile: Libreria Hispania; 1978.

Trivelato SLM. A realidade do ensino de Biologia. In: $2^{\circ}$ Encontro perspectivas do ensino de biologia; 18 a 20 de fevereiro. São Paulo: Faculdade de Educação da USP; 1986: 16-21. (Coletânea da FEUSP).

UNESCO. Manual para el fomento de las actividades científicas y tecnológicas juveniles. Bogotá ( DF), 1991. ( Série: Ciência y Tecnologia)

Vasconcelos F. Mapa revela exclusão do lazer na periferia. Folha de São Paulo, São Paulo, 2001 maio 6; cad C: $1 \mathrm{e} 3$

Vianna IOA. Planejamento participativo na escola. São Paulo: EPU; 1986. 
Vygotsky LS. Pensamento e linguagem. Lisboa: Andidoto; 1979.

Vygotsky LS Aprendizagem e desenvolvimento intelectual na idade escolar. In: Vygotsky LS, Luria AR, Leontiev NA. Linguagem, desenvolvimento e aprendizagem. São Paulo: Icone/EDUSP, 1988

Wagner W. Sócio-gênese e características das representações sociais. In: Moreira ASP, Oliveira DC, organizadores. Estudos disciplinares de representação social Goiânia: Ed. A/B; 1998, p. 3-25

Wallerstein N. Empowerment education applied to youth In: Matiella AC, editor. The multicultural challenge in health education. Santa Cruz: ETR Associates Publication; 1994. p. 153-76.

Wallerstein N, Sanchez-MerkiV. Freirian praxis in health education: research from results an adolescent program. Health Educ Res Theor Pract 1994; 9: 105-18.

Weare K. The contribution of education to health promotion. In: Buton R, Macdonald G. Health promotion: disciplines and diversity. London: Routledge; 1993. p.66-85.

Weissmann H. O que ensinam os professores quando ensinam ciências naturais e o que dizem querer ensinar. In: Didática das ciências naturais: contribuições e reflexões. Porto Alegre: Artmed; 1998.p.31-55.

Zabala A. Os enfoques didáticos. In $O$ construtivismo na sala de aula. $5^{a}$ ed. São Paulo: Ática; 1998.p.153-196

Zanetic J. Ciência, seu desenvolvimento histórico e social: implicações para o ensino. In: Ciências na escola de $1^{\circ}$ grau. Secretaria de Estado da Educação de São Paulo. CENP 1991: 7-19 
VI- ANEXOS 
ANEXO 1 


\section{PROPOSTA PARA A IMPLANTAÇAO DE UM CLUBE DE CIÊNCIAS E CULTURA}

Local: Centro da Juventude sediado na Paróquia de São José do Jaguaré, Bairro do Jaguaré, São Paulo.

\section{I-Introdução}

O IBECC-UNESCO (Instituto Brasileiro de Educação, Ciência e Cultura)Comissão de São Paulo sediado no campus de Universidade de São Paulo, vem promovendo, há anos, programas voltados para a implantação e desenvolvimento de Clubes de Ciências e Cultura.

Os programas visam estabelecer um espaço de educação voltado para crianças e jovens. Neste espaço se estruturam ações, representadas por um conjunto de atividades, que visam a formação e desenvolvimento de conhecimentos e potencialidades dos educandos participantes, estabelecendo vínculos com a comunidade onde está inserido

Desta forma, através de seus objetivos e estratégias, o clube permite completar a formação de seus participantes no aspecto educacional, cultural e social, trabalhando habilidades e capacidades, bem como as atitudes.

\section{II- Características do Clube de Ciências}

O clube, representado por um espaço físico e um conjunto de ações, é voltado para a educação não-formal, e congrega educandos e educadores de modo sistemático e organizado, comprometidos em construir e ampliar o conhecimento. Assim, através do desenvolvimento de pequenos projetos educativos, crianças e jovens, sob orientação, organizam e preparam estudos sobre os mais variados temas, nas diferentes áreas do conhecimento cientifico, cultural e ambiental, de interesse pessoal, coletivo e/ou da comunidade

Os projeios, interdisciplinares, permitem desenvolver atividades de estudo, lúdicas e experimentais, voltados ao interesse dos educandos, com diferentes idades e bagagens de conhecimento. Jovens e crianças dividem um espaço democrático, participando da escolha dos temas, do encaminhamento, execução e avaliação das diversas atividades, intercambiando idéias, partilhando e construindo o conhecimento. 


\section{III- Objetivos do clube}

São objetivos gerais do clube:

1. desenvolver atividades que contribuam para a formação científica e cultural dos participantes, capacitando-os para novas leituras do mundo;

2. possibilitar a socialização entre os educandos e sua integração com o ambiente;

3. estabelecer intercâmbio com a comunidade.

Entre os objetivos específicos destacamos:

1. estimular o desenvolvimento de diferentes capacidades: pensamento, destreza e comunicação, atuando não só na informação, bem como na formação de habilidades e atitudes, frente aos objetos e fatos que fazem parte da vida e do ambiente dos educandos;

2. estimular o desenvolvimento da criatividade através da organização de experimentos e de observáveis, permitindo a formulação de interpretações e explicações para os fatos e fenômenos do dia-a-dia, do teste de hipóteses e das diferentes formas de expressão;

3. estimular a busca de dados, seu manuseio e organização, em diferentes fontes de informação, relacionando e ampliando os conhecimentos;

4. integrar os conteúdos, dando significado à experiência cotidiana.

\section{IV- Estratégias}

Os encontros serão constituídos de diversas etapas e desenvolvimento:

- apresentação da proposta para organização dos grupos de trabalho;

- sugestão de temas e seleção de problemas para estudo, por exemplo: animais da horta, plantas usadas na alimentação, ciclo de vida do besouro, diferentes tipos de alimentos, as funçòes dos dentes, etc.

- organização das atividades a serem desenvolvidas;

- seleção de materiais;

- formas de registrar os resultados. 


\section{V- Tempo e duração do trabalho}

Esta proposta visa a implantação de um programa com duração inicial de cerca de um ano, com encontros semanais de 2 horas, para um grupo de 30 crianças, que freqüentam o Centro da Juventude Santa Cruz, no Jaguaré. O programa será aplicado por mim, Maria Augusta Cabral de Oliveira, do quadro de professores do IBECC e pósgraduanda da Faculdade de Saúde Pública da USP.

\section{VI- Resumo do currículo da executora do programa}

Formada em Ciências Biológicas pela USP. Mestre em Zoologia pelo Instituto de Biociências da USP. Professora de Educação Ambiental da Universidade Mackenzie. Ex coordenadora de Ciências do Colégio Santa Cruz. Doutoranda do Depto Prática de Saúde Pública, na Faculdade de Saúde Pública da USP.

São Paulo/ Fevereiro de 1999 


\section{ANL:XO 2}

LISTA DE CRIANÇAS - Março de 1999

* Crianças que iniciaram em março de 2000

** Crianças que sairam no final de 1999

André O. da Silva - 10 anos, $3^{4}$ série

Antonio de Oliveira da Silva - 11 anos, 3 série

*Camila dos Santos Souza - 8 anos, 2 série

Carla da S. Nascimento- 10 anos, 4 série

**Cesar Augusto de Souza - 8 anos, 1 'série

Cintia Raquel Agostinho da Silva - 9 anos, 4 série

**Claudenir Pereira dos Santos - 7 anos, 1 série

Daniela Aparecida G. Machado - 10 anos, $4^{n}$ série

**Dayane da Silva Marques - 8 anos, $1^{*}$ série

Danilo V. de Souza - 9 anos, 2" séri8

Dorothy Maria Bezerra - 9 anos, $3^{*}$ série

*Edivaneide $M$. da silva - 9 anos, $2^{*}$ série

Edilson Belarmino de Oliveira - 10 anos, 4 série

Ednaldo Geturlino dos Santos - 9 anos, $3^{a}$ série

Edson O. dos Santos- 10 anos, $10^{*}$ série

Eduardo G. dos Santos - 10 anos, 4 série

Elaine dos Santos Souza 9 anos ( $4^{3}$ série)

Everton R. da silva - 10 anos, $3^{\text {* }}$ série

Expedita C. Nascimento -8 anos, $1^{3}$ série

*Fabíola S. de Oliveira - 9 anos, 2" série

*Felipe C. M. Bezerra - 7 anos, 1 série

Fernanda Regina de Oliveira - 9 anos, $2^{\star}$ série

**Fernanda da Silva Marques - 9 anos, $4^{a}$ série

**Gilmar Rodrigues da Silva - 10 anos, 4 série

*Ingrid dos Santos Teixeira - 7 anos, 1" série

João Vitor Silvino dos Santos -8 anos, $2^{a}$ série

**Jessiar F. de Oliveira - 8 anos, 2 série

Jéssica dos S. Rodrigues - 9 anos, $2^{*}$ série

João Victor S. os Santos - 9 anos, $2^{*}$ série

Juliana Moura - 9 anos, $3^{*}$ série

*Larissa S. do Prado - 7 anos, 1 'série

** Letícia Peixoto da Silva 9 anos, $4^{\text {a }}$ série

*Luana P. Grossi 8 anos, $2^{*}$ série

**Lucila Cavalcanti dos Santos - 10 anos, 4 série

* Mayra Rosário - 7 anos, I" série

* Micaela M. dos Santos 7 anos, I" série

Mônica Magy da Costa 9 anos, 4 série

Mònica Souza de Abreu 9 anos, 3 'série

Paula C. da S. Santos - 9 anos, 2 serie 
*Rafael A. Nicolau - 7 anos, 1 série

Rafaela C. Cavalcante - 9 anos, $3^{3}$ série

* Romário dos Santos Souza - 7 anos, 1 série

**Tamires Bezerra Pereira - 9 anos, 4 " série

Tayara dos Santos Silvino - 9 anos, 4 série

Taís Souza Costa - 10 anos, 4 série

Vagner de S. Nascimento- 11 anos, 4 série

*Valdicléia de J. Santana - 9 anos, 3 série

Vanderson Costa de Jesus - 9 anos, 3 série

Vanessa Costa de Jesus - 9 anos, $3^{2}$ série

**Wellinton de Moraes Minervino - 11 anos, 2" séric

William H. dos Santos -11 anos, 4 série 
ANEXO 3 


\section{TERMO DE CONSENTIMENTO}

Srs Pais ou Responsável

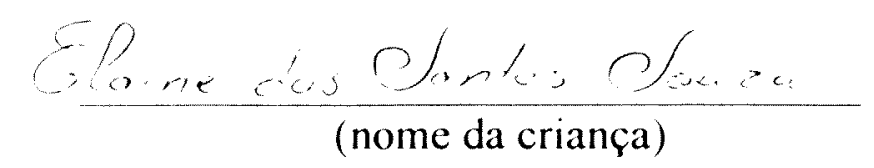

Neste segundo semestre de 1999 será iniciado um trabalho com as crianças de 7 a 11 anos, do período da manhã, no Centro da Juventude Santa Cruz.

Este trabalho pretende que as crianças aprendam noções e conhecimentos sobre Os Alimentos e A Saúde e será aplicado pela professora Maria Augusta Cabral de Oliveira.

Nas aulas, as crianças irão participar voluntariamente, de várias atividades e experiências e serão convidadas a falar sobre o que acham do trabalho, em entrevista.

Todas as informações serão apresentadas pela professora em seu trabalho de pesquisa, que está sendo preparado em parceria com o Centro da Juventude e a Faculdade de Saúde Pública da USP.

Gostariamos de contar com seu consentimento,

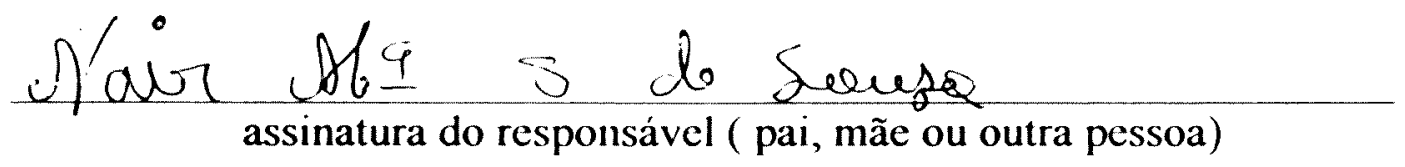


ANEXO 4 


\section{Prezada Professora}

Sou professora também e, há uma ano, venho desenvolvendo um trabalho no Centro da Juventude (CJ), na Paróquia de São José, com as crianças de 7 a 10 anos, no periodo da manhã. Desta forma organizei junto com os jovens, um Clube de Ciências c Cultura voltado para trabalhar os conhecimentos de Cienncias e Saúde.

Como estou levantando dados para uma pesquisa, considero muito importante ouvir sua opinião a respeito do referido trabalho, e se ele $t \mathrm{~cm}$ se refletido de alguma forma $\mathrm{cm}$ sua sala de aula. Assim, peço sua colaboração para o preenchimento do questionário $\mathrm{cm}$ anexo.

Aproveito para antecipar meus agradecimentos pela sua gentileza $\mathrm{cm}$ colaborar com esta pesquisa c coloco-me à sua disposição para maiores esclarecimentos ou um contato pessoal se assim julgar pertinente.

Cordialmente,

Maria Augusta C. de Oliveira

Relação dos alunos que frequentam o Clube e a sua escola:

\section{1 a série}

César Augusto de Souza, Expedita C. Nascimento, Fernanda R. de Oliveira, Jessica F. de Oliveira

\section{2a série}

André O. da Silva, Antônio de O. da Silva, Doroty M. Bezerra, Everton R. da Silva, Juliana Moura, Paula C. dos Santos.

\section{3a série}

Ednaldo G. Santos Filho, Mônica S. de Abreu, Tais S. Costa, Vagner S. Nascimento

\section{4a séric}

Cíntia R A da Silva, Daniela A Gonçalves Machado, Elaine S Souza, Edilson B de Oliveira, Gilmar R da Silva, Leticia P da Silva, Lucila C dos Santos, Mônica Magy da Costa, Tamires B Pereira, Tayara S Silvino. 
ESCOLA: E. E. P. Profo foaro Erux losta ALUNO(S) fessica Franga de Uleveira

SIERIL: 19

1- No geral como é (são) o(s) aluno(s), que frequenta(m) o CJ, na escola? (dificuldade de aprendizagem, relacionamento, participativo, indisciplinado)

C aluna apresenta interesse pilos istudes asisinclando o centéido eom, farilidade, é partecipatio mas aulas como também discyalinada Deu rufaje mamentio corn a propessora i colegas é satefoterus

2- Especificamente como é o desempenho deste(s) aluno(s) na área de Ciências/Saude? Você percebeu alguma modificação em seu comportamento ou desempenho?

Cpresenta desempentho satisfatér pois $24 \mathrm{~m}$ nc decorrer do ano demonstrande intebisse em orgumentar em expor suas idruas. Gosta di pen- sar, observar e particyar das aturdades.

3- Ele(s) comenta( $\mathrm{m})$ sobre o trabalho desenvolvido no Clube/CI?

Ele(s) tentam ensinar o que viram no Clube aos companheiros de classe?

a fésica comenta a respeito das ateridades da apostla como exemplo nomear as figuras coEla gosta de trabalhar a esirita deb mesmas. zer gosta de realizar essas ativadades tin pra 4. Adicione outras observações que julgar pertimentes de gratificante mossas criancas terem a spiturida avo conhecimentos de Ciêneiar saúde listá presinte. G eriance aprente de ferma prazeresa mai dican.

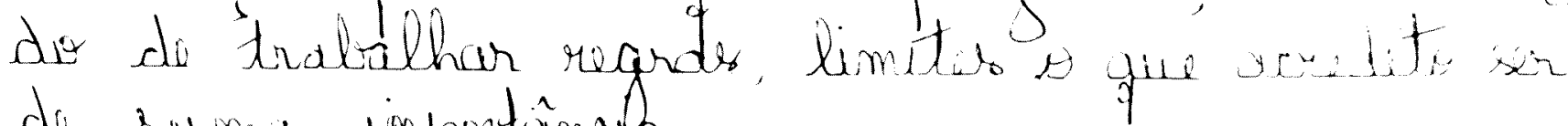
de seema impontioncib. 
ANEXO 5 


\section{MINUTA - PROJETO HOR'TA}

Neste ano de 1999, foi implantado um programa denominado (\%ube de Ciência e ('ultura, no Centro da Juventude Santa Cruz (CJ), que está estabelecido junto à Paróquia São de José, no Jaguaré. Este programa está voltado a uma parcela das crianças moradoras da favela Vila Nova Jaguaré, com idades de 7 a 10 anos.

O programa tem como proposta mais ampla estimular diferentes capacidades e desenvolver a criatividade, atuando não só na dimensão da informação, mas também da formação das crianças.

O programa, já iniciado, vem desenvolv

endo atividades voltadas para a alfabetização científica e cultural dos participantes, capacitando-os de um lado com novos conhecimentos e, de outro, possibilitando a integração entre as crianças e o estabelecimento de interações com seu entorno.

O tema trabalhado se refere a ALIMENTOS, NUTRIÇÃO, SAÚDE, sendo que está previsto a construção e o cuidado de uma horta, como uma das etapas do programa. Para tanto pensou-se na possibilidade de estabelecer uma parceria com a Sociedade Brasileira de Silvicultura (SBS), uma vez que em encontro anterior com a Eng ${ }^{\text {a }}$ Andrea Maffeis, esta apontou o interesse da instituição no estabelecimento de trabalhos voltados para a educação ambiental, segundo propostas educativas e objetivos pedagógicos similares aos desenvolvidos nos trabalhos do $\mathrm{CJ}$.

Esta minuta visa explicitar o projeto assim distribuído:

a) ÁREA: Educação Ambiental/Ciências/Saúde

b) TEMA: A Horta

c) POPULAÇÃO ALVO: 30 crianças de 7 a 10 anos, vinculadas ao Centro da Juventude Santa Cruz

d) LOCAL DA HORTA: Sociedade Brasileira de Silvicultura, situado à R. Marselha, 1180 ,-Bairro do Jaguaré

e) PERIOODO: Outubro a Dezembro de 1999, com possibilidade de continuação para 2000

\section{f) OBJETIVOS ESPECÍFICOS:}

As crianças deverão:

- planejar a organização do espaço para a instalação da horta;

-identificar os instrumentos usados no trabalho da horta;

-participar da preparação dos solo e canteiros;

- preparar o plantio de sementes e mudas;

- observar e identificar as várias fases de crescimento das plantas;

- cuidar e manter os canteiros. 
g) CONTEÚUDOS

1- O que é a horta?

* Localização

* Solo

* Plantas: sementes e crescimento

* Animais

2- Preparação e Cuidado

* Instrumentos

* Adubagem

* Manutenção: remoção de pragas e irrigação

3- Colheita

* Período de colheita

* Preparação e armazenamento dos vegetais colhidos

h) MATERIAL

adubo/sementes/ instrumentos: pás, ancinho, rastelo, regador, enxada/estacas/barbante

i) PESSOAL ENVOL VIDO

-M. Augusta $C$ de Oliveira- professora responsável pelo desenvolvimento e aplicação do programa junto ao $\mathrm{CJ}$ e desenvolvimento da horta;

-Andrea Maffeis- responsável pela orientação técnica e de campo, pertencente ao quadro de funcionários da SBS.

j) CUSTOS

instrumentos: 4 jogos pequenos ( pás e ancinho) a $\operatorname{Cr} \$ 6,00 \mathrm{cada}=\operatorname{Cr} \$ 24,00$

2 rastelos grandes.a $\mathrm{Cr} \$ 11,00$ cada $=\mathrm{Cr} \$ 22,00$

2 pás grandes a $\mathrm{Cr} \$ 9,40 \mathrm{cada}=\mathrm{Cr} \$ 18,80$

1 vanga grande a $\mathrm{Cr} \$ 7,90=\mathrm{Cr} \$ 7,90$

3 regadores a $\mathrm{Cr} \$ 9,10$ cada

$=\operatorname{Cr} \$ 27,30$

TOTAL $=$ Cr $\$ 100,00$ 
ANEXO 6 


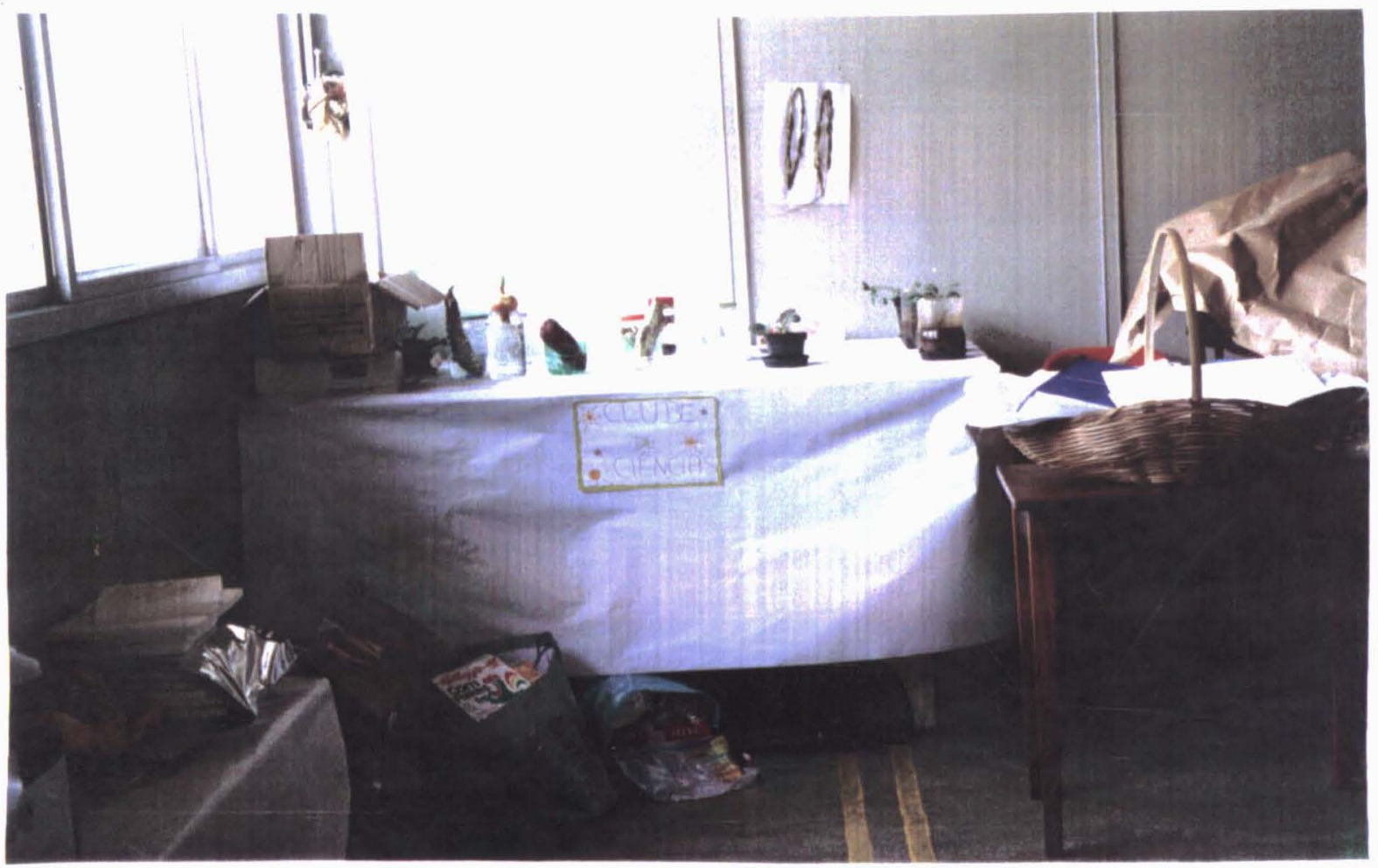

Fig. I - Vista geral do "cantinho" do clube

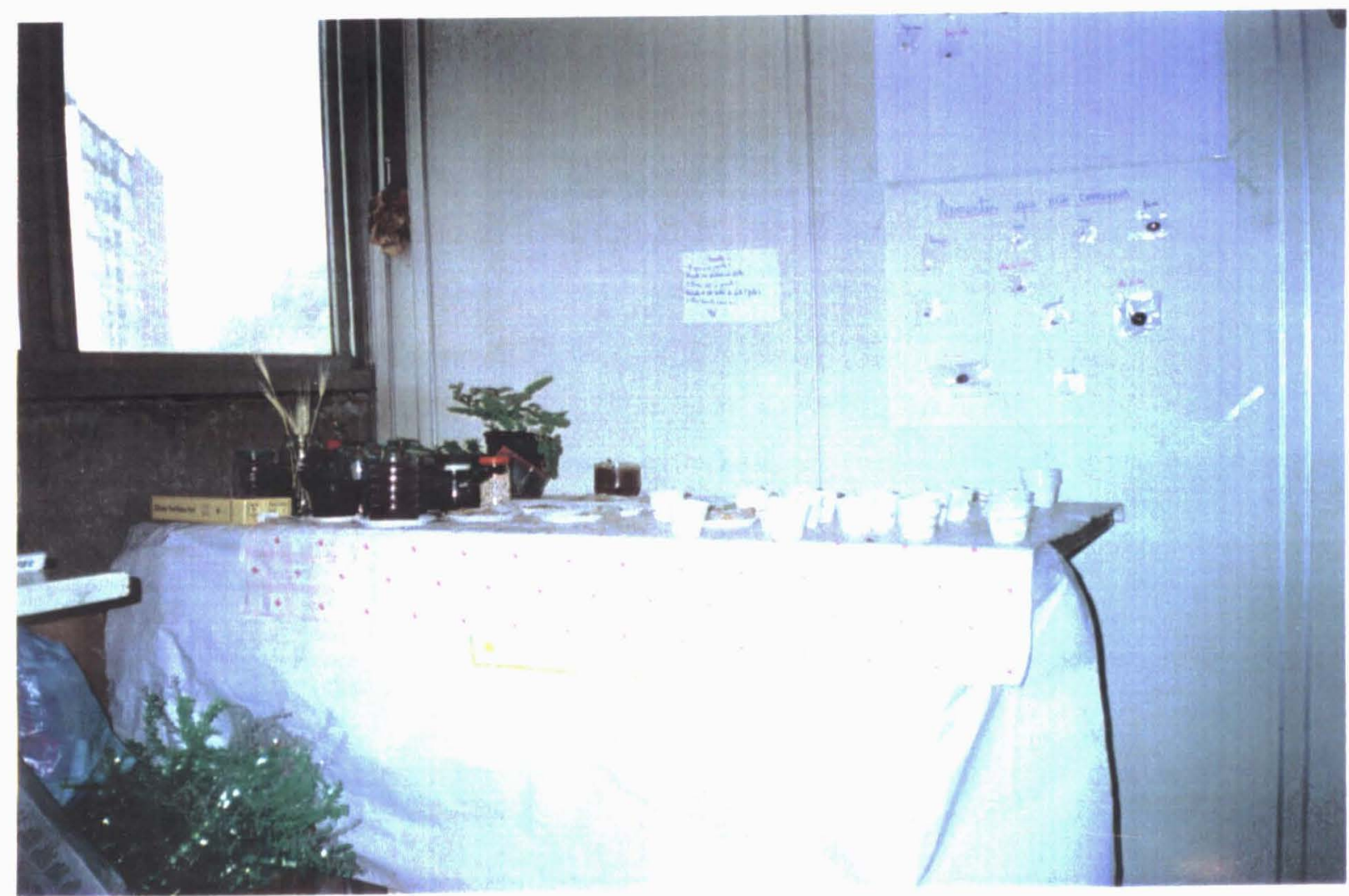

Fig. 2 - Vista geral da mesa com os potes de germinação 


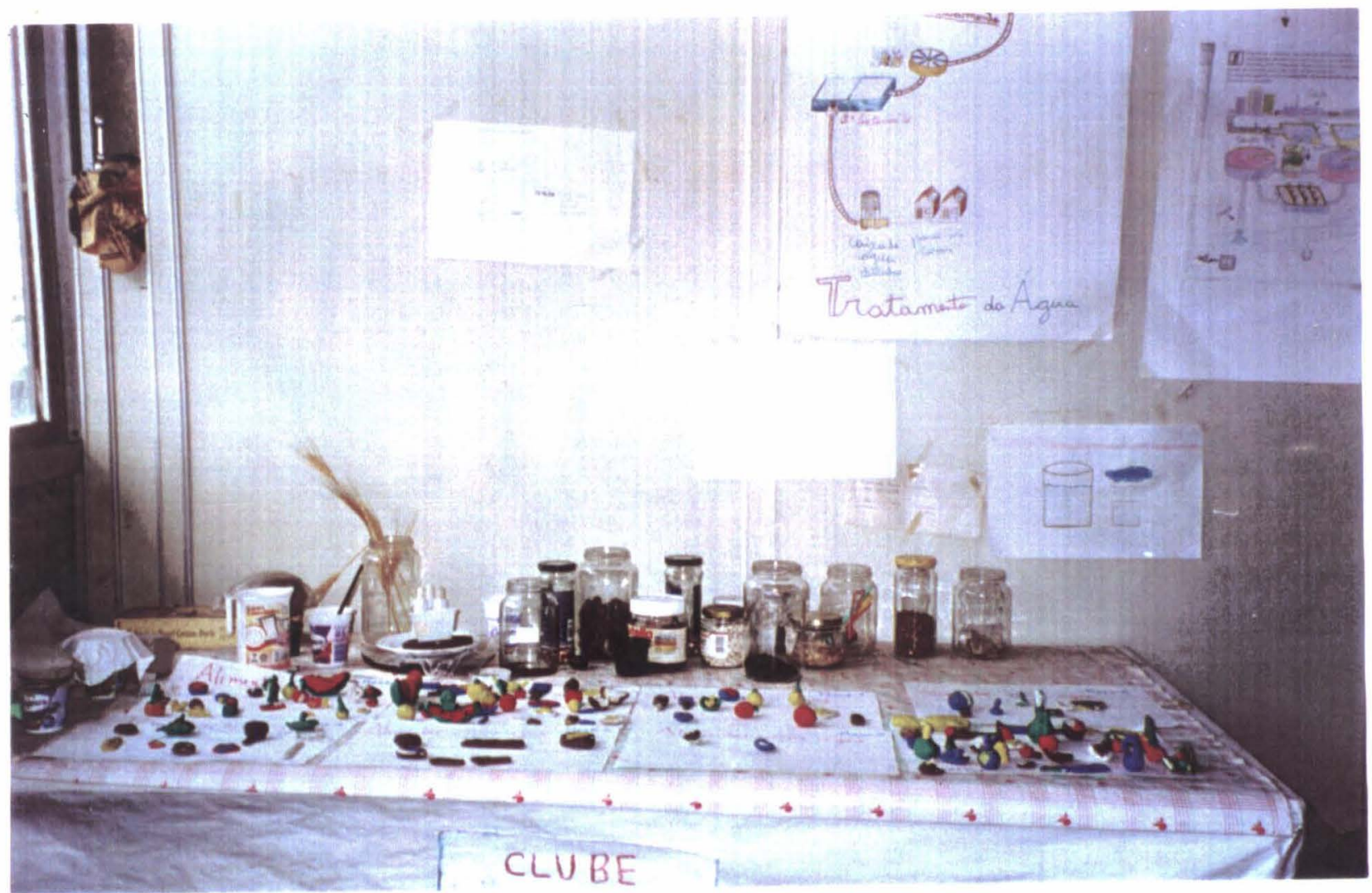

Fig. 3 - Detalhe da mesa com experimentos e trabalhos executados pelas crianças

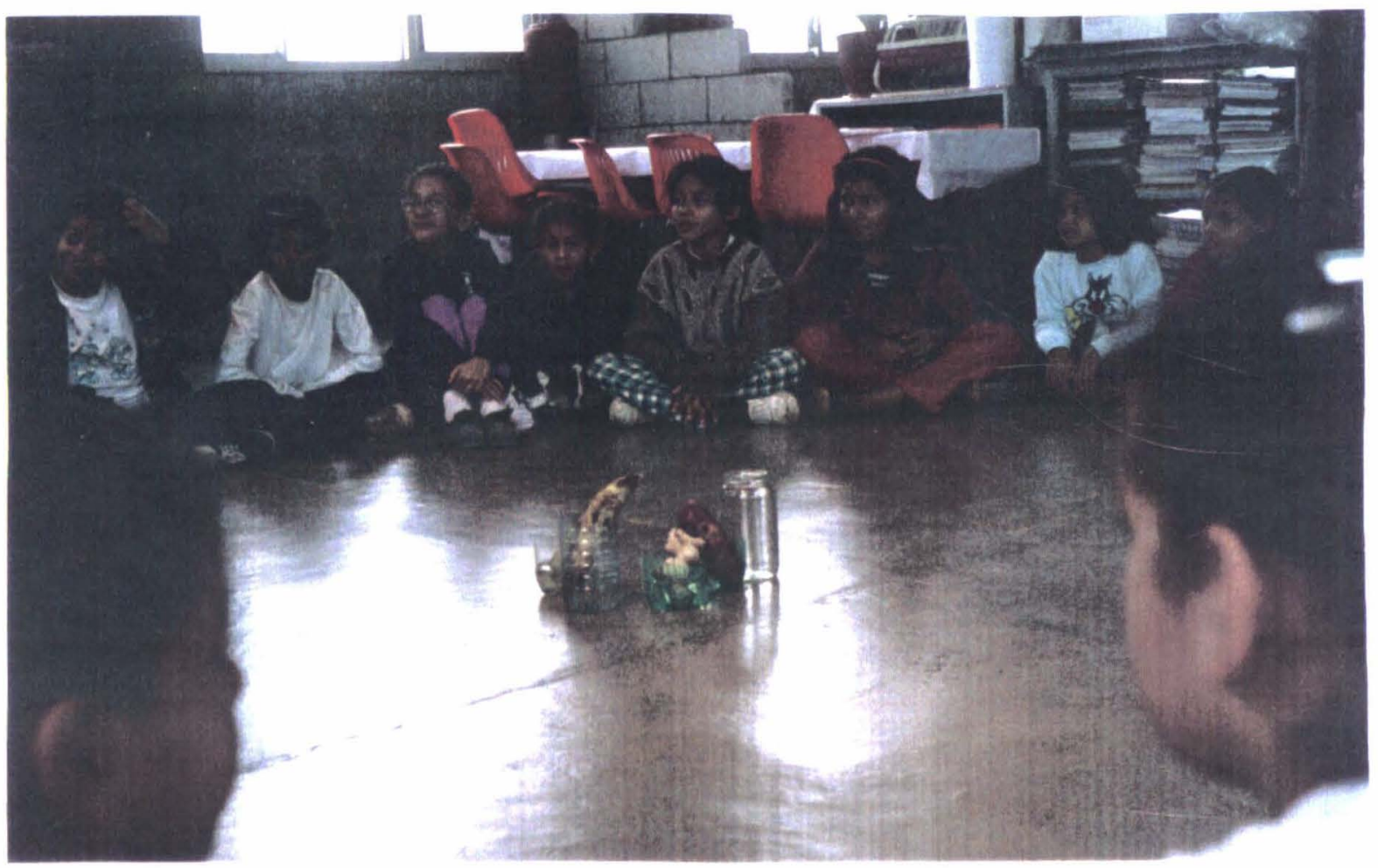

Fig. 4 - As crianças na roda 


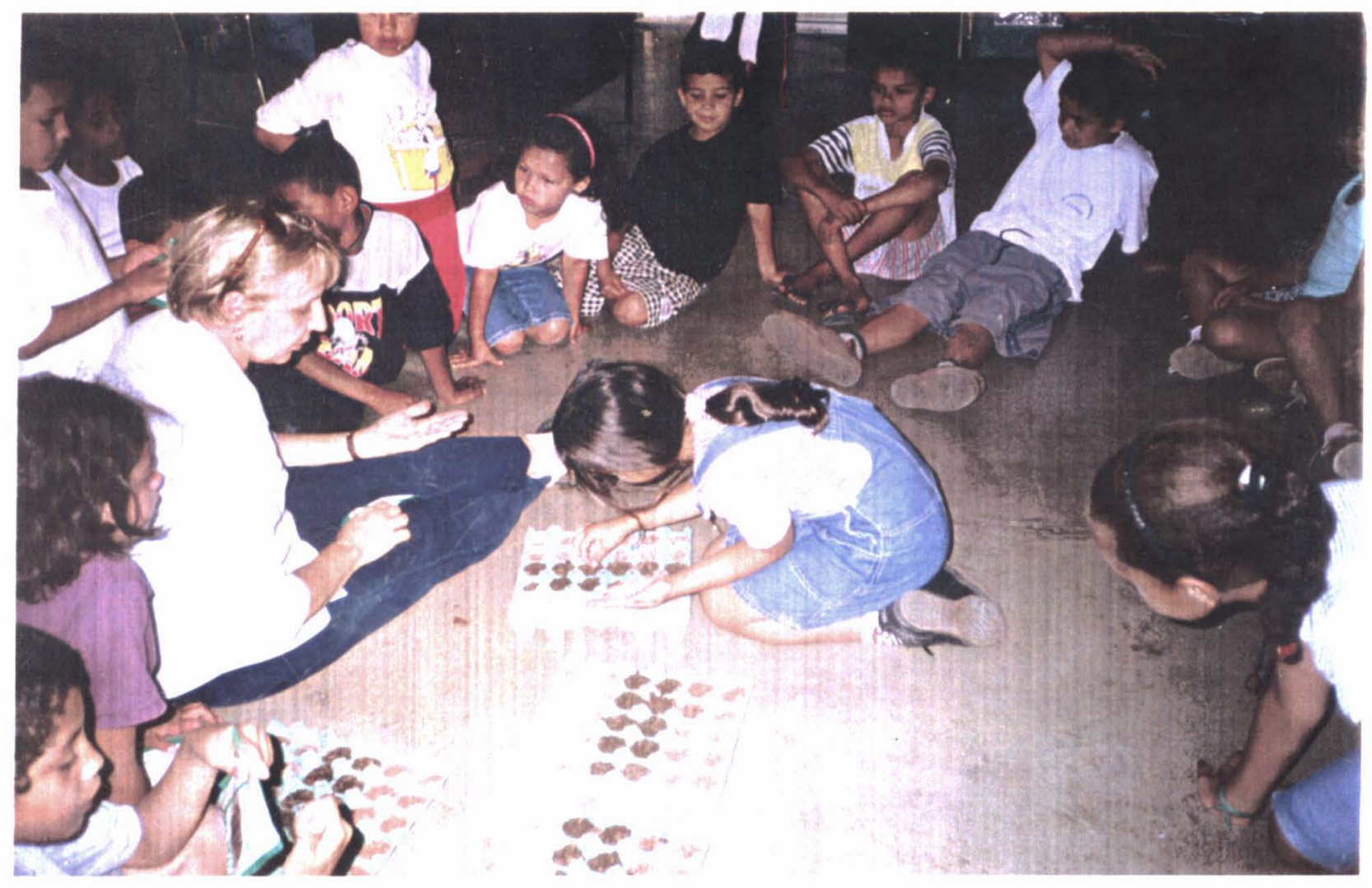

Fig. 5 Trabalho no clube: preparação das sementeiras para verificar a germinação em diferentes tipos de solos 
Jamires
.2105199

Fig. 6 - Registro sobre a transformação dos alimentos

Haca do a a é

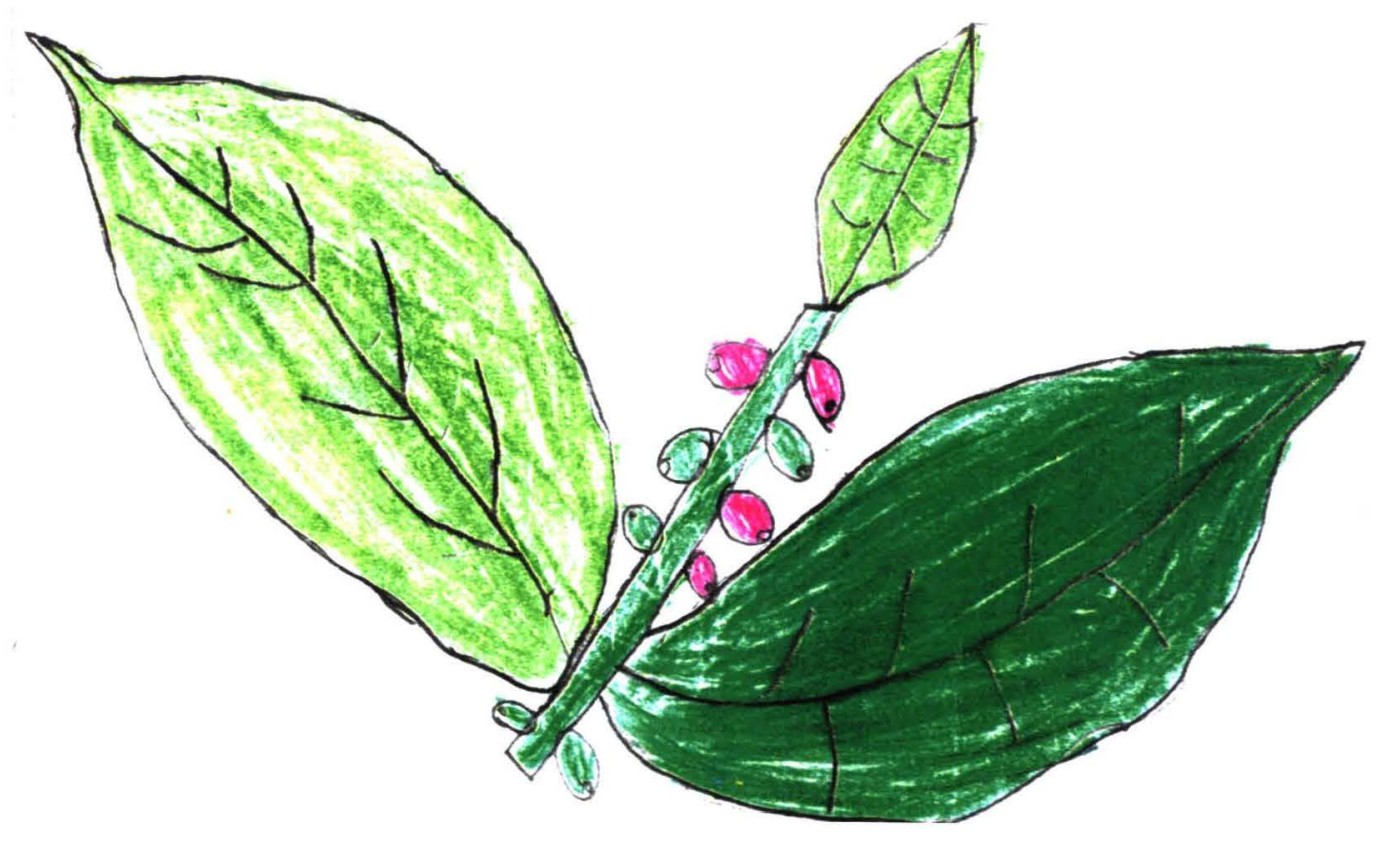

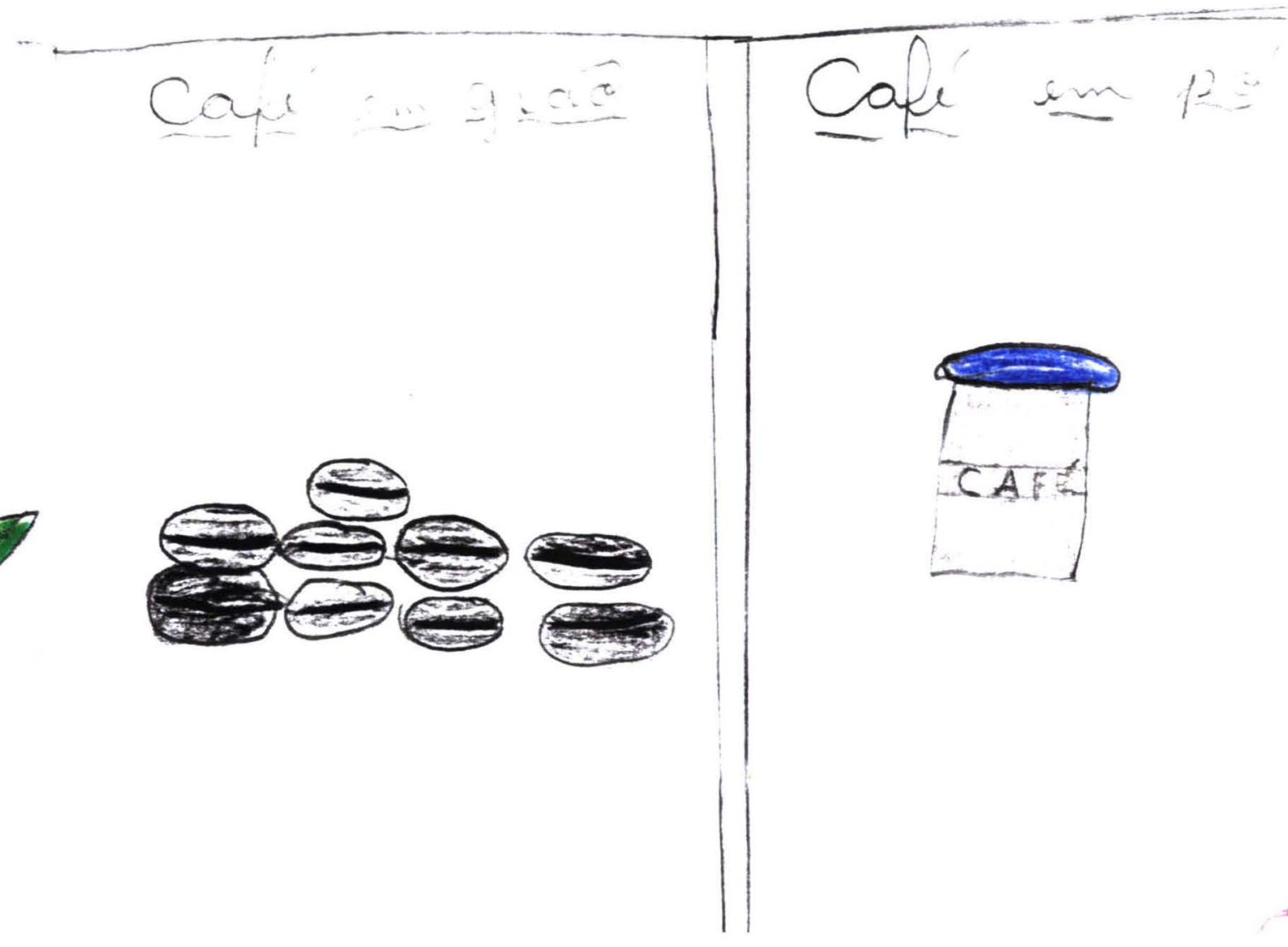


Fig. 7 - Registro apresentando a germinação e desenvolvimento das plântulas de feijão

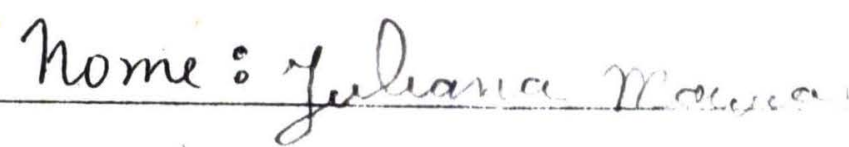

Dide:

Desenhe a semente de fijä̃.
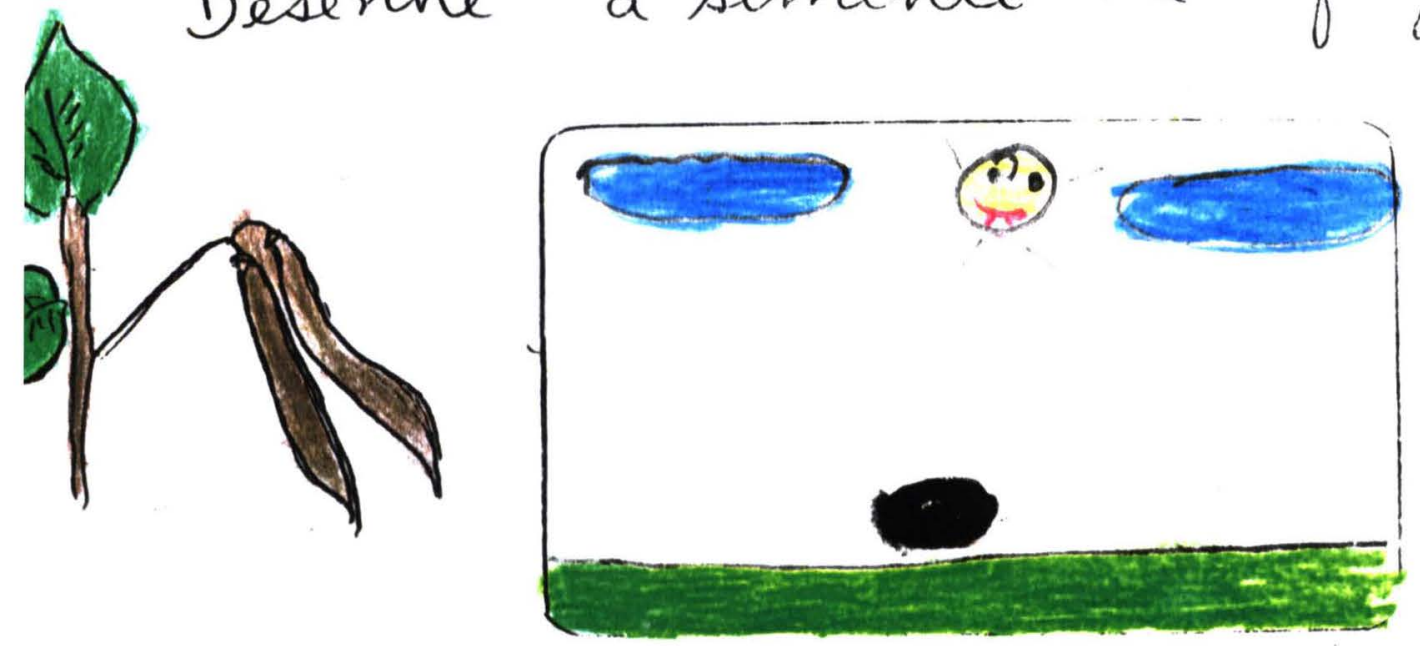

Desenhe 0 que acontece com o feija $\tilde{\omega}$ no pires com algodaio molhado

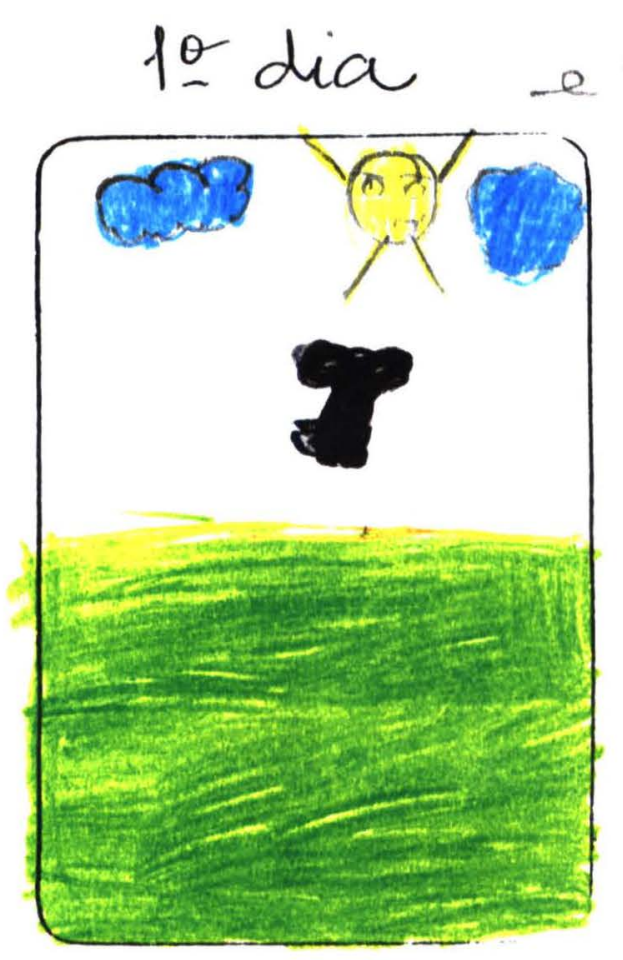

30 dia 

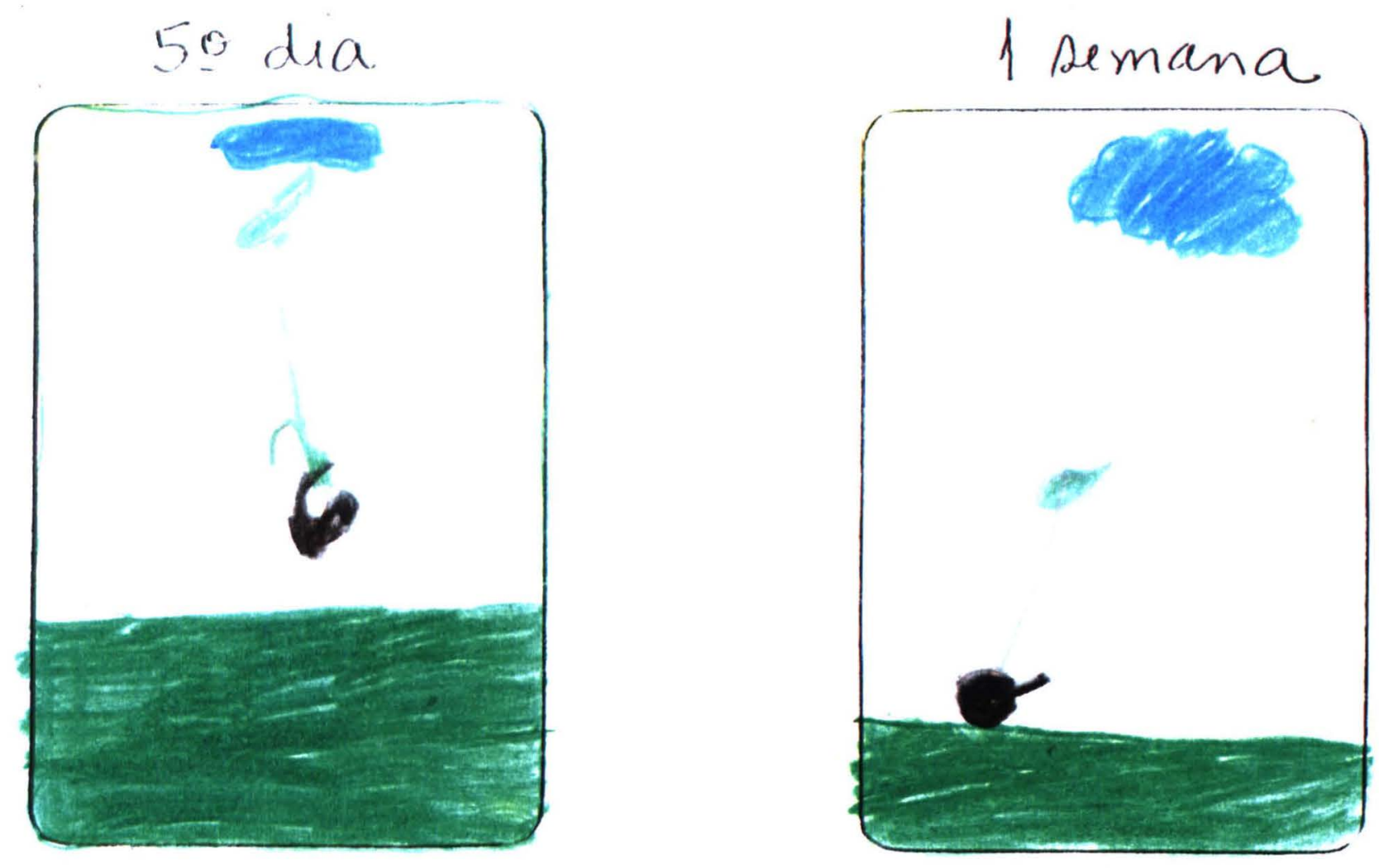

15 dias
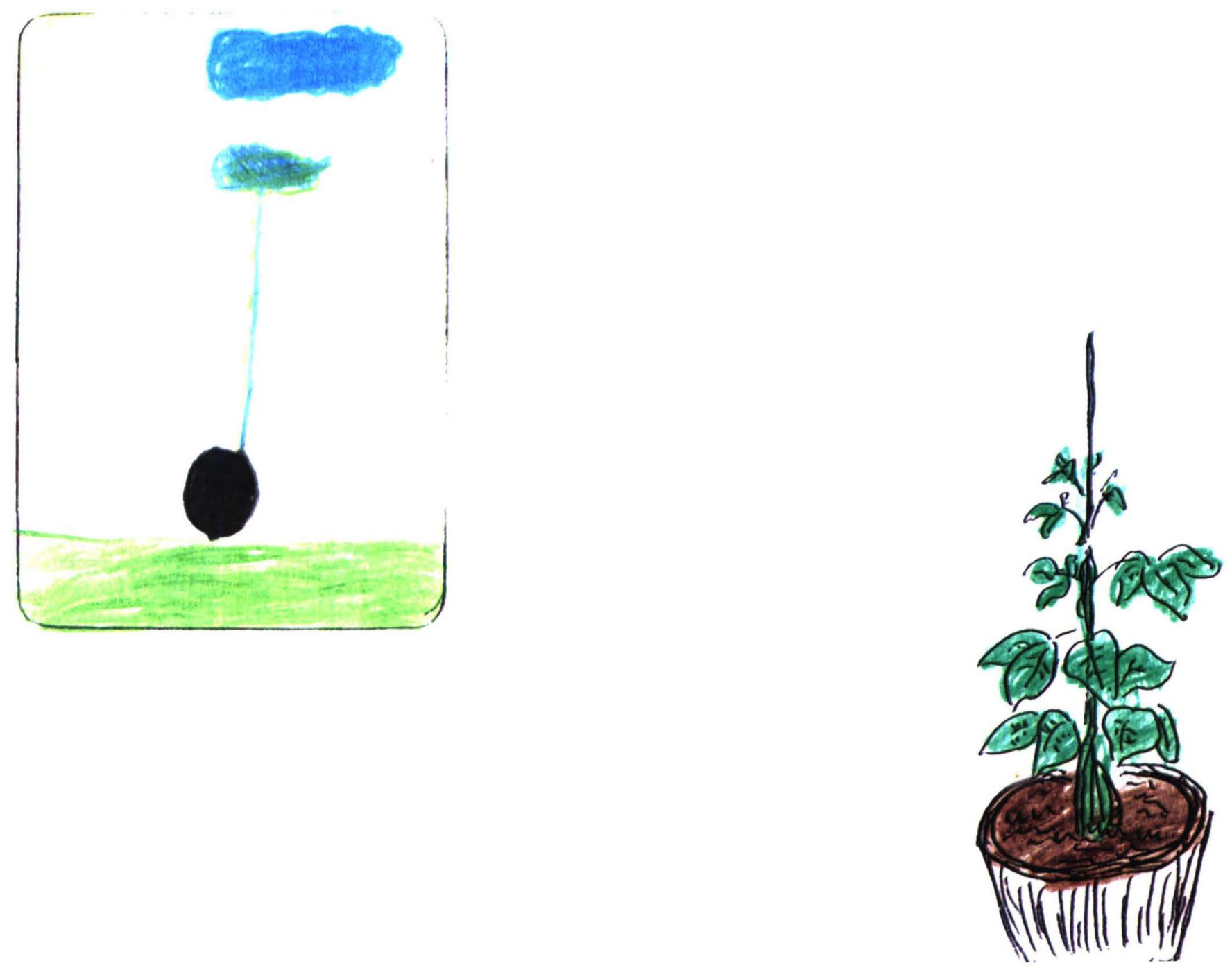

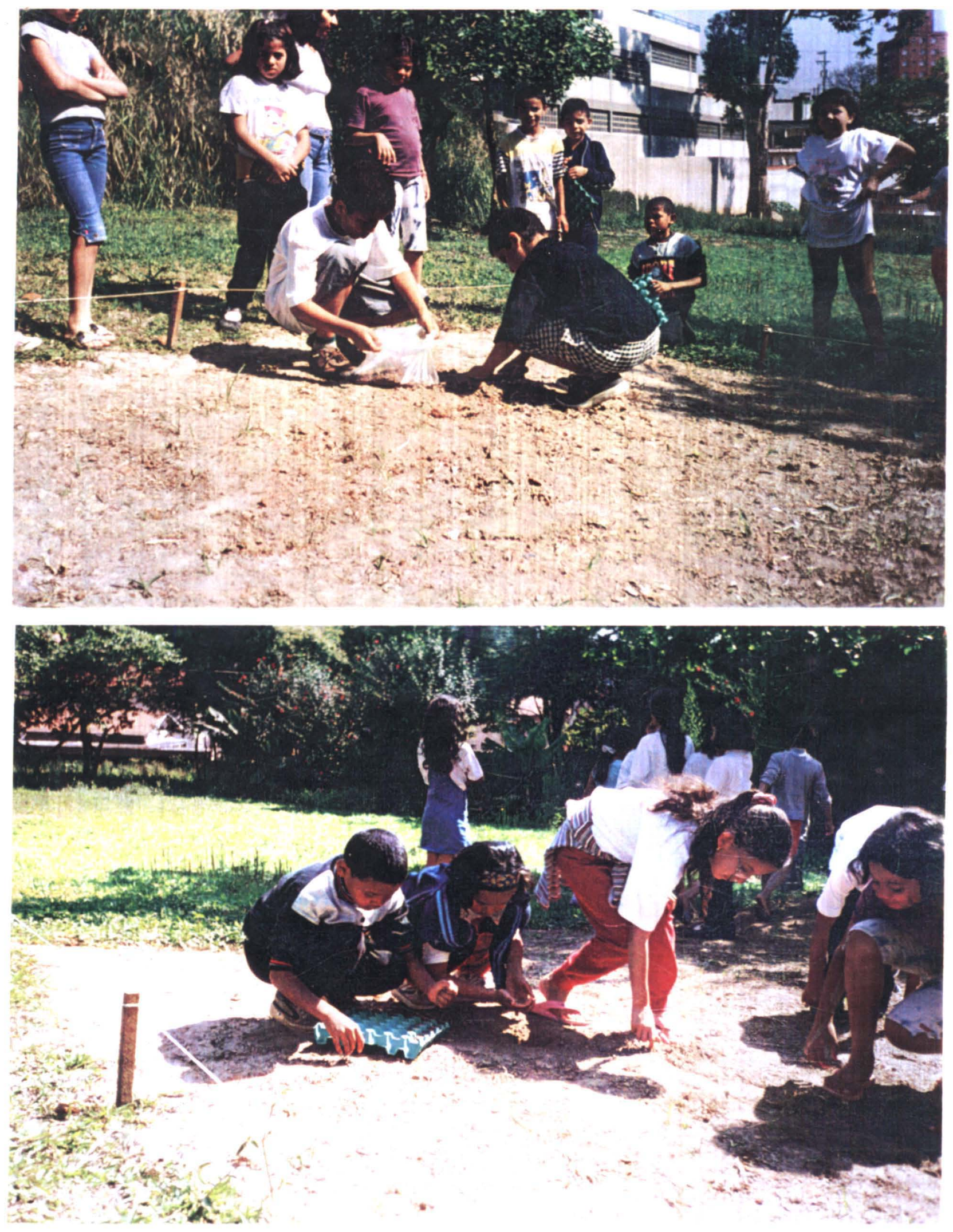

Fig. 8 - A construção da horta: coleta de amostras de solo para testar a germinação 


$$
\begin{aligned}
& \text { Ea: }==
\end{aligned}
$$

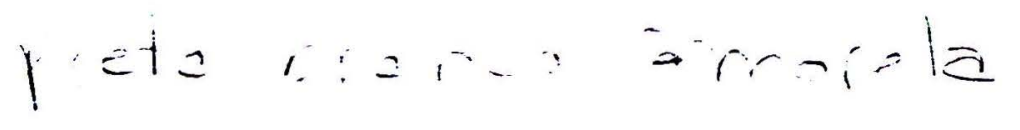

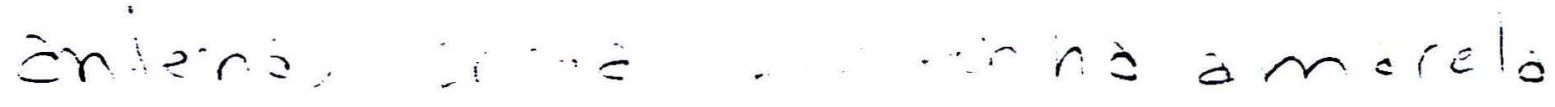

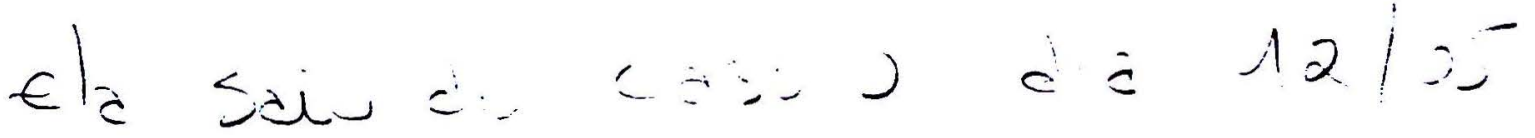

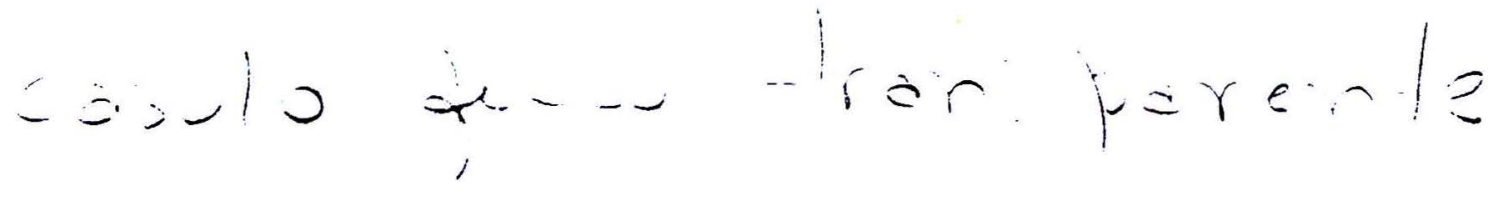

$$
\begin{aligned}
& \text { Elagurda - feira } 19 \text { de maio } \\
& \text { Uimas s locilidatas }
\end{aligned}
$$

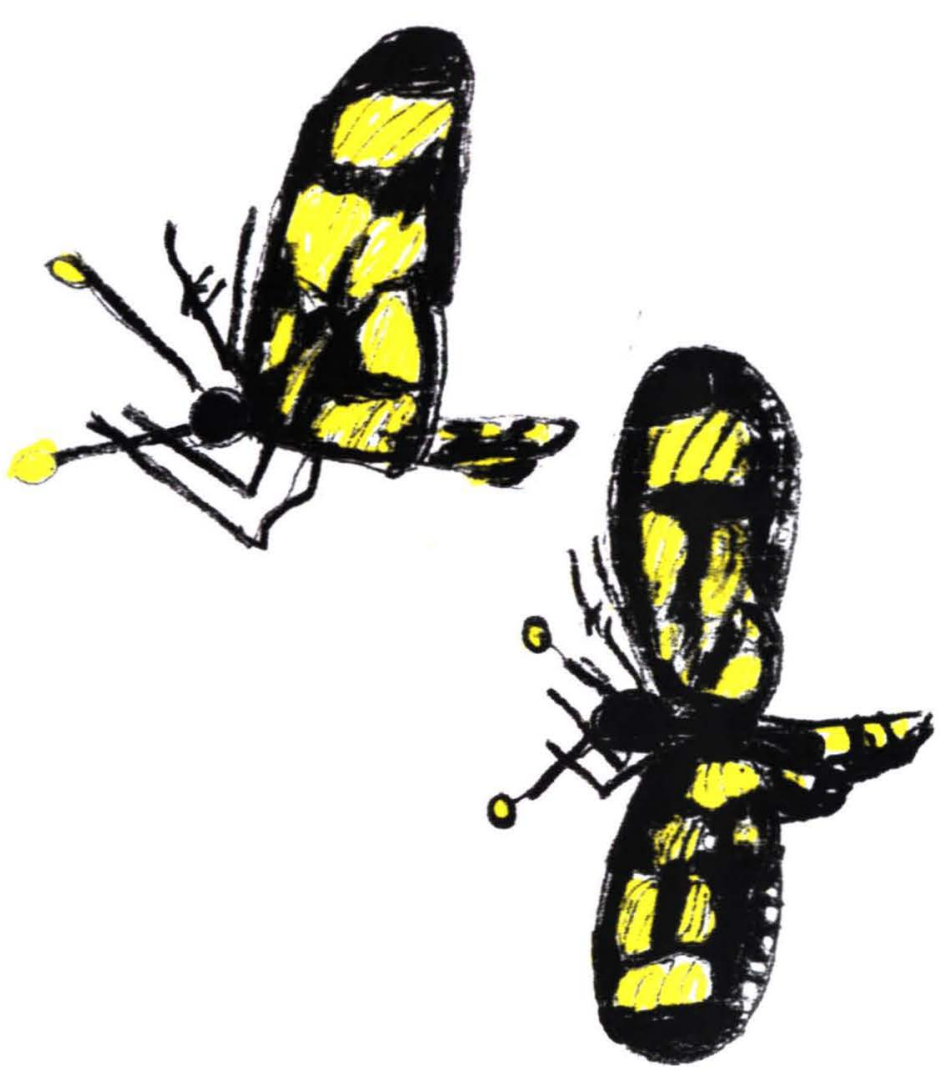

Fig. 9 - Registro com anotações apresentando as borboletas nascidas no viveiro do clube 


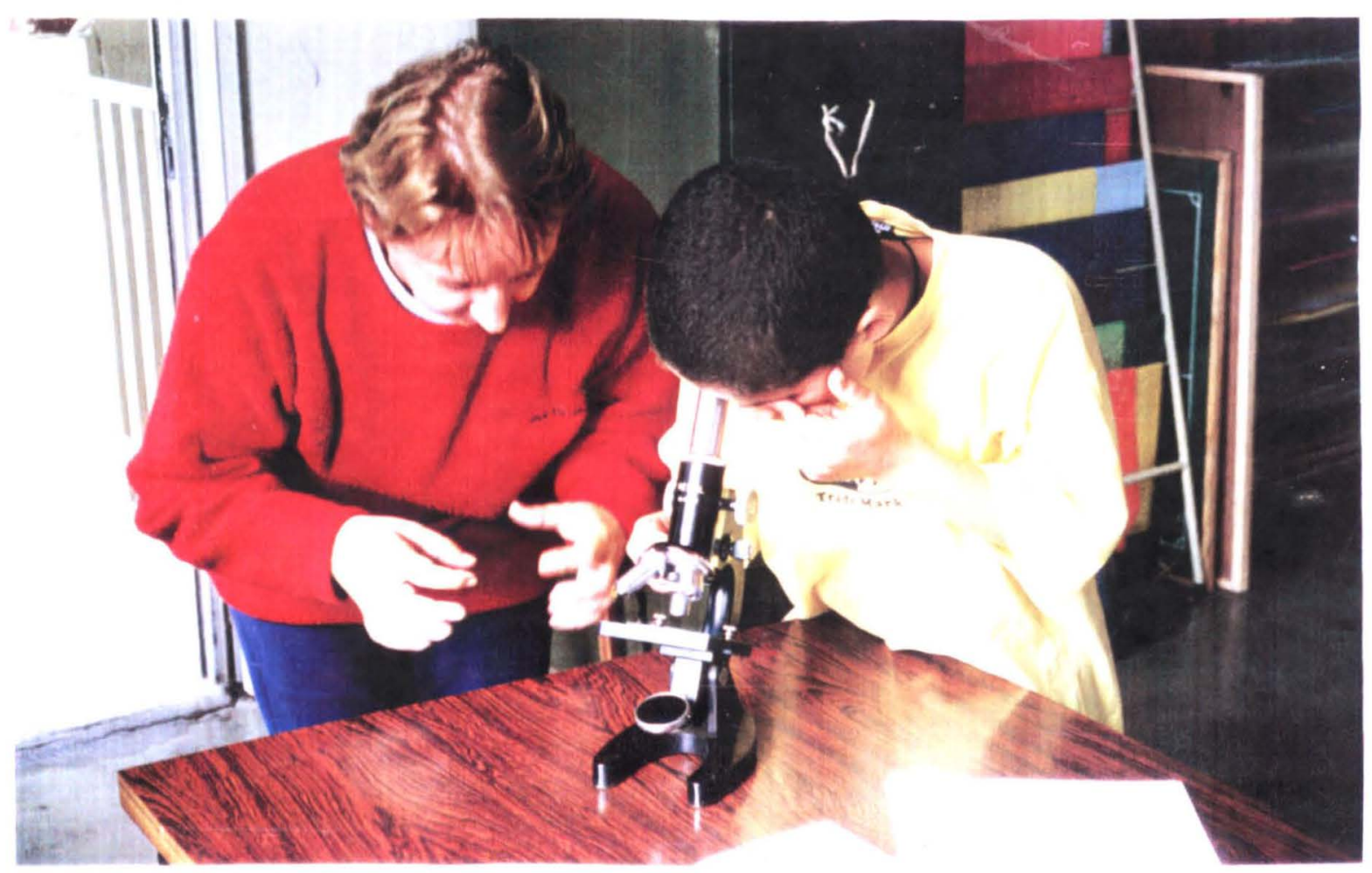

Fig. 10 - Trabalho de observação ao microscópio 
Picróbra birlo do micra copio

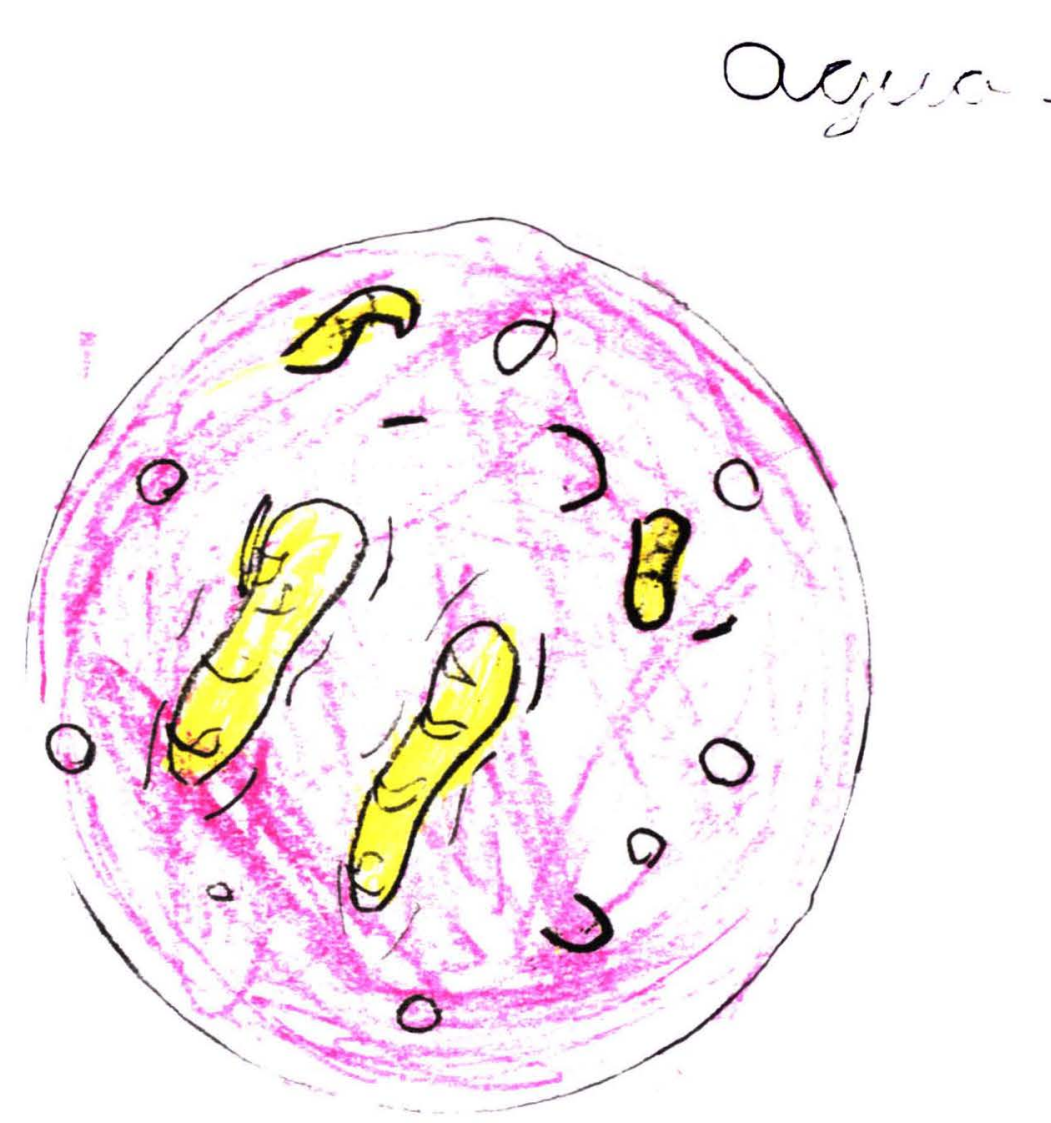

Fig. 11 - Registro apresentando observações feitas ao microscópio: Água suja 